\title{
Владимир Казаков
}

\section{Ошибка живых}

Роман

Verlag Otto Sagner München · Berlin · Washington D.C.

Digitalisiert im Rahmen der Kooperation mit dem DFG-Projekt „Digi20“

der Bayerischen Staatsbibliothek, München. OCR-Bearbeitung und Erstellung des eBooks durch den Verlag Otto Sagner:

http://verlag.kubon-sagner.de

() bei Verlag Otto Sagner. Eine Verwertung oder Weitergabe der Texte und Abbildungen, insbesondere durch Vervielfältigung, ist ohne vorherige schriftliche Genehmigung des Verlages unzulässig.

«Verlag Otto Sagner» ist ein Imprint der Kubon \& Sagner,Gmb伊. Kazakov - 978-3-95479-542-0 


\title{
ARBEITEN UND TEXTE ZUR SLAVISTIK • 8 HERAUSGEGEBEN VON WOLFGANG KASACK
}

\author{
Владимир Назанов \\ O WHEHA $W H B$ B \\ pomah
}

I

1976

München Verlag Otto Sagnerin Kommission 
Der russische Originaltext des Romans "Ošlbka žlvych" wird hier erstmals vorgelegt; er wurde im Herbst 1970 in Moskau geschrieben. Eine deutsche Obersetzung "Der Fehler der Lebenden"erschien 1973 im Carl Hanser Verlag München. Dort sind von Vladimir Kazakov ferner erschienen "Moi vstreçi s Vladimirom Kazakovym" 1972 und in Obersetzung von Peter Urban "Meine Begegnungen mit Vladimir Kazakov" 1972. Anstelle eines Vorworts sei auf die Rezension "Absurder Samizdat" in Neue Zürcher Zeitung 15.8 .1974 , S. 39, verwiesen. Die Manuskriptvervielfäligung ermöglichte Prof. Dr. Felix Philipp Ingold, St. Gallen. Die Herstellung der Druckvorlage ubernahm Frau Karin van Ackern, M A Beiden sei gedankt.

\section{Eavisiscre}

Siáaisolclictne

Múnonen

Als Manuskript vervielfaltigt

Alle Rechte vorbehalten

Gesamtherstellung Walter Klelkamp - Koln 
$\Pi a \mathcal{R} m u$

Петра Бромирсного 
Был шар эвмной

Првкрасно схвачвн лапой

сумасшвдшего.

За мной,

БОRTВСA HEYERO!

Велимир Хлебкихов 


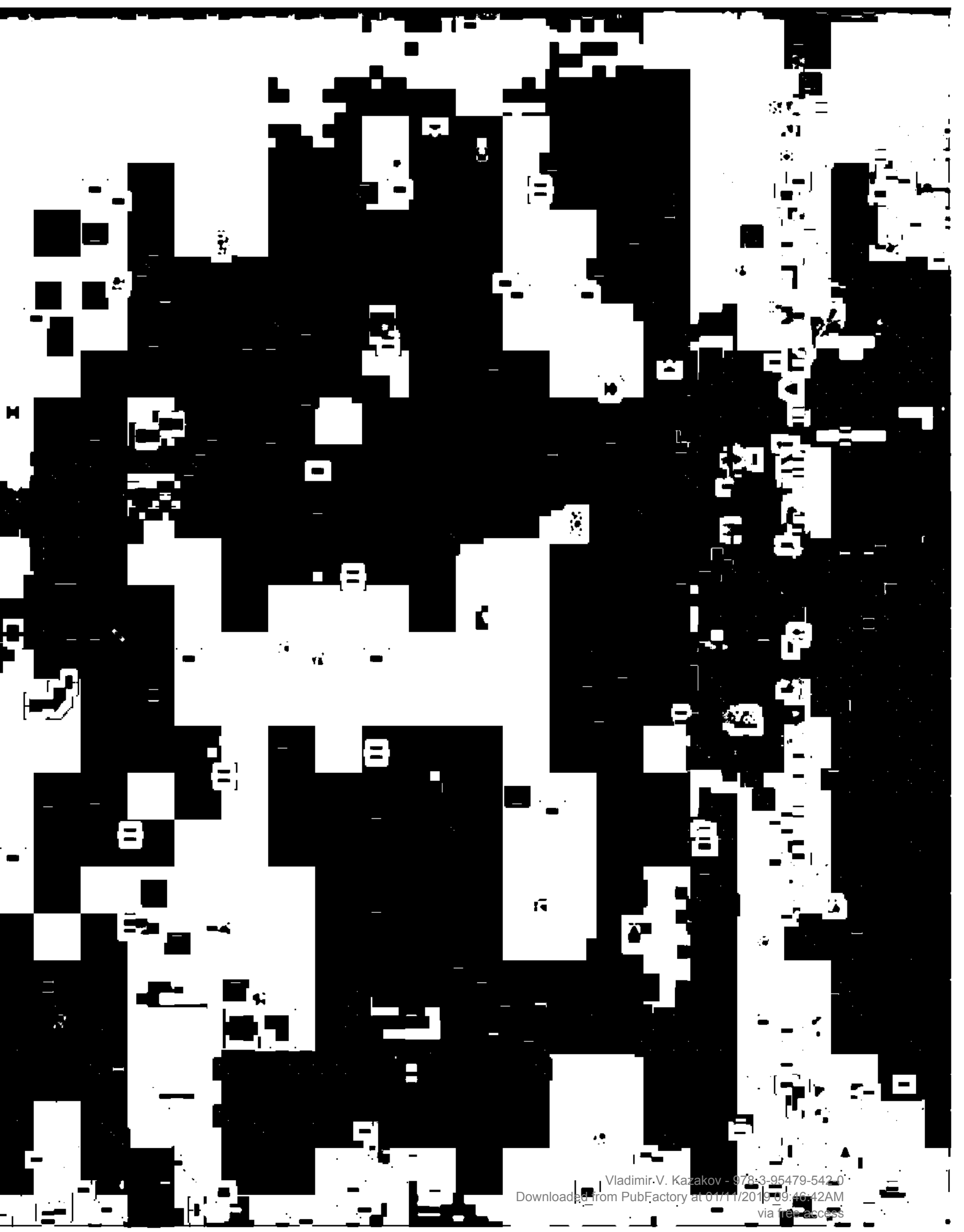


Y A C T B I E P B A

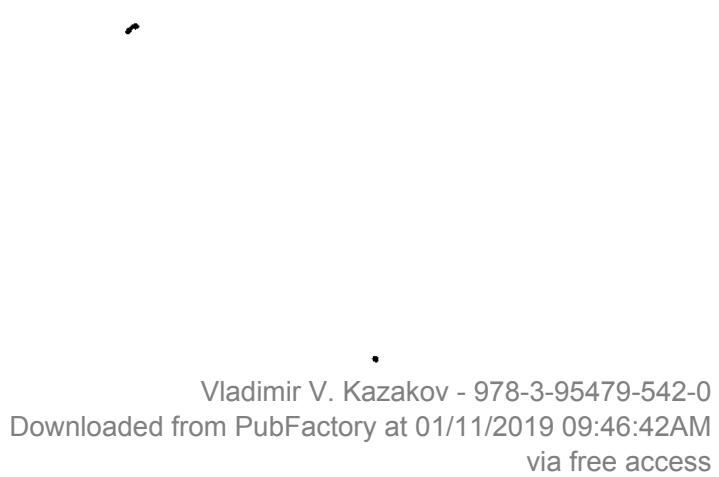




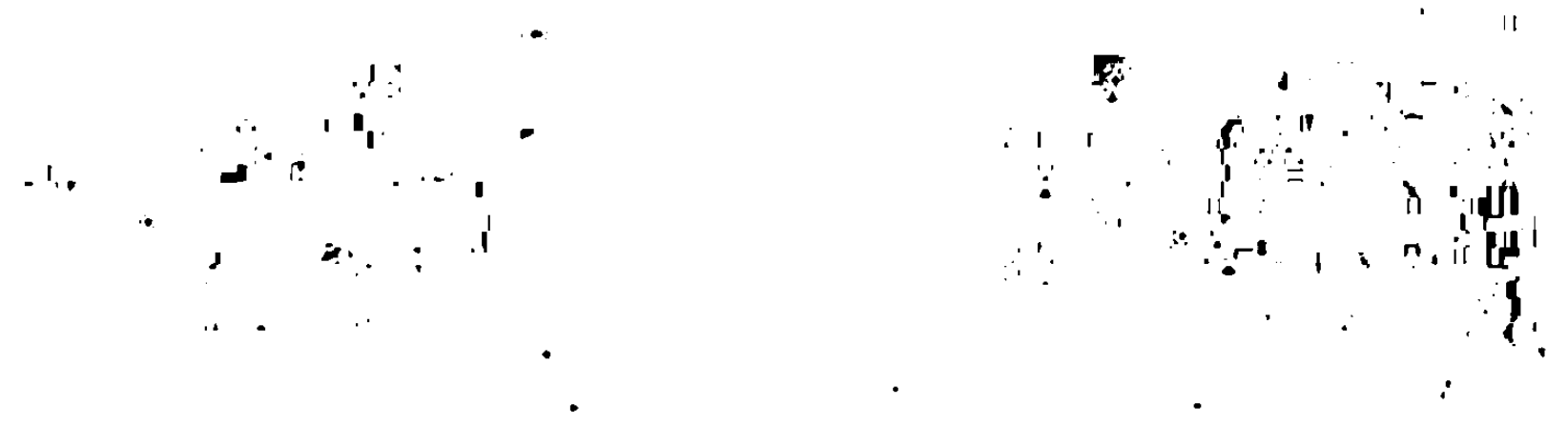

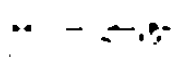

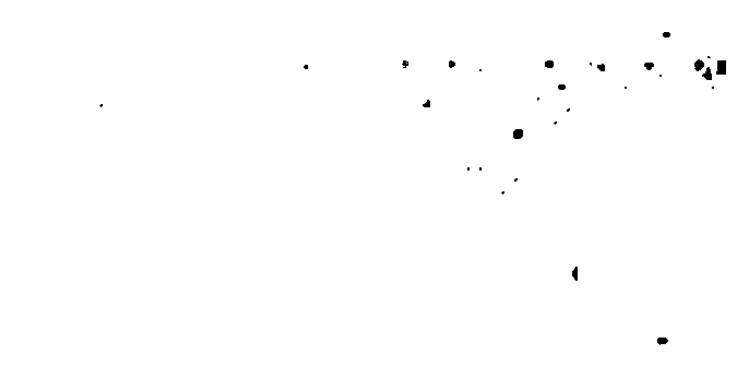

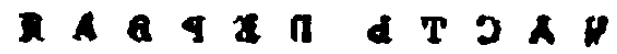

.

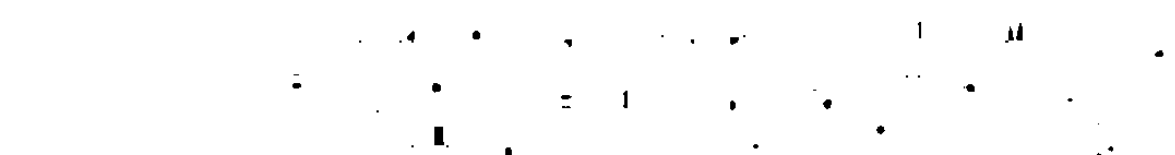

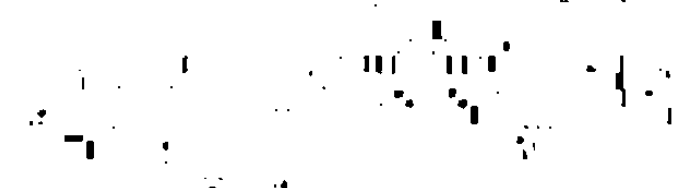

II 
Последняя өспышна утра осветила бледные лица пассажиров. Повзд мчался неизввстно нуда и отнуда. Нз Варшавы в Моснву. Нолеса стучали и все нинан не моглн обогнать туман, ноторый был жвлтого цввта.

Двов пассажиров сиделн напротнв друг-друга, однн лицом ГлАдя на Моснву, другой - на Варшаву. Оба молодыв людн, тот, ноторый на Моснву, был невысоного роста, чернонудряв, наная-то одна постоянная мысль была плотно сжата вго тонними, бвз нровинки, губами. Он молчал в тант стуну нолес. Другой, тот, что н Варшаве, был, напротив, тих, молчалив н неразговорчнв. Страннов у него было выражение лица. Наэалось, он н наной-то другой далений мир смотрели друг-другу в глаза.

Туман мчался, нрнча под нолесами. Нанонвц, они рөшили заговорить. Один из них был одет тепло, в меховой полушубон. ДруГой же - другой же. Вот нан они заговорили:

- Что, эябно? - спросил рассвянно ТОт, Что.

- Да, признаться, прохладно. Я не омидал, что онажется тан. Я вще не отвын от Шввйцарин.

- От Шввйцарин?! Эн вас! Право!... И что же, вы рвшили понинуть сию страну, или она вас понинула? А?

- Нв энаю, нан вам ответить. Я ведь был болвн.

Н он стал охотно отввчать на вопросы, моторне нвохотно задавали ему со всех сторон. Он представился, нанонец. Сназал: "Владимир Нстленьев". У второго нашлось имя: Нван Пермянов. Третнй, наной-то странный, все время хотвл угодить, но этого всего времени не было.

Тот, что в полушубнв, вдруг стал рассназывать. Туман охнул и посинел. Вот вго Кстория: он едет. В Моснвв его ждут на вонэале. Нто? Федор, пронутивший все И оставшнйся посреднне. (Он назвал вще неснольно имвн И неснольно несчастий). Однажды он вошел в ювелирную лавну... но преждв... но вще првждв - странная женщина шла вдоль беэлюдной набврешной. Пролетая мимо ве волос, мимо мостов н холодных волн, был ввтер. Она шла одна, но назалось. Пермянов бросился вслед ветру и прнзрану... Ноле- 
са стучали, повзд все дальше отьезжал от Варшавн, но н Моснвв приблизился не на много. На Пермянове был полушубон, ноги его были обуты в тяжвлыв сапоги, он хотөл улыбнуться, но нв эахотөл. Он тан и остался С нснрнвлвнными в усмвшнв губами.

Фамилия третьего попутчина, того, что угомдал (ному? часам? времвни?), была Нунлин. Нунлин стал лихорадочно первчнслять свонх детвй и рассназывать. Они жнли в Моснвв. Нена умерла, оставнв грудного младвнца. (Мир умер, оставнв что?). Нногда он эансннвающе улыбался, н улыбна морщила лицо пьяннцы. Ему было лет 60 - 55. Нос, лиловый от холода, от пьянства И снова от холода. Он эаглянул в глаэа Пермянова:

- Тан это жв Эввлина Владимировна Алабова! Тан это жө... да!

- Отнуда ты знавшь?! - вснрнчал Пермянов.

- А вот и энаю, знаю, знаюl - забормотал торжвствующв, - все знаюl Ведь этот вөтер - мы ман раз с понойным Алхнмовим нз погребна поднимались, а тут - этот вөтвр! Ха-ха-ха!...

- МолчиІ - нрнннул Пермянов. Он был бледен, нан смерть, сөнундная стрелка в ужасв бросилась прочь.

Повзд мчался, НСтленьвв вдруг занашлялся. Он нутался в дорожный плащ заграничного помроя, напюшон был огромный нвскладный, но пассажнры-попутчнни ужв давно усмвхнулнсь.

- Тан что же, не вылвчили? - спросил вго Нунлин участливо, И видно бЫло, что смвх в нвм давится самим сабой.

- Тан что жв, нв вылвчили? - мдали вонруг.

- Мвня лечнли в нлинине донтора Ногансона, - сназал Нстлень8в, - славний чвловвнІ Он был но мнв тан добр!... Увэжая... я взял болезнь с собой... Меня провотали... донтор Ногансон, вго Свмья, Пацивнти...

- А вы были ногда-нибудь в люблены?... Былн?! Да? Что?!... Что я говорил! Ну нонвчноl Aх, расснаэывайтв меl Не расскаэнвайтв! ...

- Право, я не знаю... это нв тан...

Нунлнн, наконвц, рассмвялся, дал волю смвху, и повзд рванулся н полетвл от его жутного хохота. Но Кстленьев, Назалось, нв замвчал. $\mathrm{H}$ сам он наэался.

Пермянов хмурился все сильнев, Моснва угротающе приближалась. Одно нолвсо особвнно надрывно стучало. Пермянов онинул 


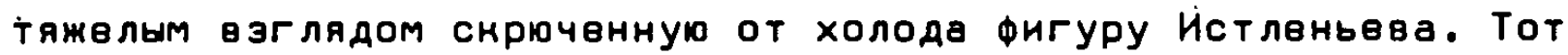
тан и вхал ввсь остатон пути в этом тяжвлом вэгляде поверх плаща с мапюшоном.

Однажды, прогуливаясь по Шввйцарин, он встретил дввочну-налену, ноторая сидела на снамьв в снвврв. Он подошел. Прошло нвскольно "нет" Н неснольно "да". Молчанив длилось, то возниная, то продолжаясь. Нвбо над ними высилось, наной-то один луч нруто падал вдоль сөрой стены облаков. Нанонвц, тишина поназалась нввыноснмой сама свбв, она что-то снаэала, өымолвила пошввйцарсни. Но эти двов не поняли, нвподвнжно стояли. Дввочна Поднялась И Мөдленно двинулась. ОН Авинулся в Аругую сторону следом эа ней...

Нунлин вытер слезы, ноторыв еще прыгали на вго щенах. Он перевел дух: "Ну и нуl Ну и наІ...". Повзд мчался, ошалело гудя म Аाмя.

Увидя эту жвнщину, Пермянов увидел. ОН слишном долго проСтоял неПодвижно, ОН Слишном долГО ПрОстоял неподвнжно, ОН. Все нэменилось эа это врвмя, начнная С, Н нончая з. Нз погребна поднимались пошатнваясь, люди И шли, натынаясь на воздух. Ветер без роду, бөз племвни. Рвна стала стальной, сталь стала рвчной. Старуха-юродивая вслух молилась нвнзвестно ному. Н этот ненэвестно нто нв был милостив.

Однажды, брвясь перед эөрналом, Нунлин вдруг увидел свбя. Он сраэу же отвернулся, но зөрнало упорно продолжало смотрвть вму в спину. Однажды вдвовм С Алхимовым они спустились в погрвбон. Был поэдний ввчер, Он эатянулся, часы огибали нанов-то препятствнв. Оба были пьяны, обв судьбы лежали рядом. Там, эа ствной шумела рвна. Медлвнно сигналя огнями, шли баржи, волоча за собой свинцовые чврныв небеса. Неввдомая ниному жвнщина шла. Она наэалась нвсущвствующвй - настольно всв вокруг нвв сущвствовало. Тяжелыв твмныв волосы и рөсницы - вот. В погребнв становилось все теснев. Двов - Алхимов и Нунлин, цепляясь за железныв перила, вибрались на воэдух. 
Пароходство в Намсном бассвйнв вознинло в науале XIX столетия. Первым пароходовладвльцвм был Нунлин (однофамилвц или однонвт?), ө 1817 r. Постронвший на Понввсном заводе (Солинамсного уөзда) два парохода, однн в 36 , а другой в 7 сил. Трвтий пароход вго, там же постровнний, ходил в $1821 r$. по Наме и Волге до Рыбинсна. Horда в 1843 r. с онончанивм срона привилегин Бврдта, сдвлалось свободным пароходствс по всвм рвнам Империи, пароходнов двло начало быстро развнваться. В 1848 г. образовалось Пермснов пароходнов общество, в следующем году номпания Ганса и Төта построила для Пврмсной пристани пароход в 60 сил. В 1651 г. отнрыла сөон двйствия Намсно-Волжсная номпания, эатвм явились общвства "Навназ и Мернурий", "Самолвт" и проч. Н воэнинли постоянные пароходо-строКтөльныв заводы И өврФн.

Девочну-налвну звали Мадлон. Молчанив выступило из-за дерввьев. Истленьвв подошел И остановился возле. Возле отшатнулось было в испугв, но дввочна сдвлала энан руной - всв успононлось Нстленьвв хотвл что-то сназать, но оназалось, что он ужв нвснольно минут Говорит бвз умолну, И дввочна смотрит на него вдаль. Он остановился. Где-то далвно часы нинан не могли сдвинуть ночь с места.

Поглядвв на свов отражвнив в зврналв и в уасах, Он И там, И там увидвл блвстящве будущвв. Тольно на часах нв было с той жв точностью уназано врвмя. Пермянов не швырял двньгами, он НХ отшвырнвал. Подорвав нутвмами и пьянством ногда-то могучвв здоровьв, Он подошел $\mathrm{H}$ Свврнающвму онну.

OHHO

Вы странный чвловвн.

ПEPMЯHOB

Я ослышался? Нли вы?

OHHO

Осльшался, овндвлся - это всего-навсвго глаголы. А я - онно. 
ПЕРМЯНОВ

A Hет - BU?

\section{$\mathrm{OHHO}$}

Прощайтв, понлоннтвсь от меня вам.

\section{ПЕРМЯHOB}

Вот эагадна! Это я сам с собой? или с собой, но не сам?... ГM...

Тут в номнату ввалилась толпа гоствй. Нвноторыв нз них били өму знаномы. Они любили Пермянова за өго щедрость, а не любили - за свою снупость. С ними была одна дама.

$$
1-\text { ด ГOCTb }
$$

Что это, НОчь КлН нОчь?

$$
\text { 2-И ГOCT6 }
$$

Спросите у них самих!

\section{3-ด ГOCTЬ}

Тольно прошу бвз шутон К бвз других доназатвльств собстввнного сущвствования!

$$
\text { 4-ด ГOCTb }
$$

Не забывайте, будьтө добры, что среди нас - дама. Я пврвнй не забыл.

\section{ДАМА (}

Здравствуйтв! Добрый ввчвр! Я вошла стрөмитвльно, омружвнная блестящей свитой, одна... Наной-то бвзумный художнин првследувт мвня последнив Авв-три ночи. О, Нан нраснво безумие при светв фонарей! 0 !...

\section{ПЕРМЯНОВ}

Пожалуйста, садитесь в это вот нресло. Жаль, уто я не могу првдложить того жө самого и безумию. 
Ха-хаІ... То-всть, проститв, ах-ах!

\section{6-ด ГOCTb}

Приручить можно что угодно. Дажв ствну. Гладишь 8в, и она ничвго...

AAMA

Шумя платьвм, раэввваясь перьями шляпы, я рванулась н зврналу, но оно обратилось в бвгство. А я не побоялась бы выйти против целой армин зөрнал!

$$
1 \text { - П ГОСТЬ }
$$

Сввчн пугливн, н төмнота тожв.

\section{ДAMA (}

Что с вами? Вы молчали и вдруг тан странно эамолчалиІ... Ногото Увидвли в онне?

\section{2-ด ГОСТЬ}

Ну, на этот отввт өы вряд ли дождвтвсь вопроса...

Нунлин обожал свонх двтвй. ОН пил, чтобы нв сойти с Ума от любвн н ним. После смерти жены он сгорбился вщв сильнев. ОДнажды он упал и долго лежал на улицв. Наступала ночь. Дождь возвращался. Под мостом, согнувшнсь, стояло хмуров нвбо. Гдето Алхимов тоснливо подсчитнвал, снольно столвтий осталось вму прожить аля того, ЧтобЫ Стать тысячелетним.

Повзд мчался прочь от Варшавы. Нстлвньвву было холодно, желөзными зубами лязгала ночь... Мадлон - пленница сөоих төмных волос, глаза свернали, двв или трн ночн были одноврвмвнно... Фонарь эакашлялся и погас... Однажды он спроскл вв. Она улыбнулась. С твх пор однатды не пренращалось. Детснив игры детөй...

Пермянов неотиданно сназал НСтленьеву: "Чем-то ты мнв полюбилсяl Ей-богу, не знаю чем, но полюбился. Приходи но мнв, не 
пожалевшь!... Приходи и ты!" - обратился он н Нунлину. ТОт чуть не подпрыгнул на свовм меств: "Приду, обязатвльно приду! Эх, да что говорить!...". И он тан радостно махнул руной, что запланал.

Тепврь уже Моснва мчалась навстречу им. Набервжныв взирали трввожно на нвбо, а небо трввожно взирало выше. Чернвла вода.

Был подан чай. Пробило полночь.

\section{3-ค ГOCTЬ}

Чай, часы, онна - три врвмени. Н все три не совпадают.

$$
\text { 4-म ГОСТЬ }
$$

Чай - из всвх самов позднвв.

$$
\text { 5-ค ГOCTЬ }
$$

Насн - Самов прозрачнов.

$$
\text { 6-ค ГОсть }
$$

Онна - самов бвзумнов.

\section{ДAMA}

ГЛотон чая, Глотон полночи, Глотон бвзумия...

Нунлин - свдвющий чвловвн лет 55, с малвньними свврнающими глазнами, С нрасным носом, С сумрачным небом над Головой. Он был страстным нартвжнином. Огромныв вынгрыши соввршвнно разорили вго. Он вместв со свовю свмьвй нов-нан сущвствовал на мелние проигрыши.

Часто, прислонясь н парапвту набврежной, он стоял, шумвла вода. В погребон спуснались вечернив люди.

Алхимов был шулвром и философом. Обе эти страсти, занлючвнные в таном твсном пространствв, влияли одна на другую, взанмно друг-друга облагоражнвая.

И өот однажды, ногда они обнявшись (Нун. И Алх.) поднимались из погрвбна, страннов видвнив првдстало их взорам. Нх взорам. 
AAMA

Нам странно ночь понаставила эти дома, играя в город! Стремитвльно Идя по улицв, я задвваю ного-то, ного - нвизввстно. Он следует за мной на незнаномом языне, нругом - бөз пятнадцати полночь, бөзумец! Я снрялась во тьме, но өго шепот, во тьмв фонарвй... Танов бывавт тольно наяву или во Сне.

$$
\text { 2-ค ГOCTb }
$$

В тольно!

\section{$3-ด$ ГOCTb}

Ах, я задрвмал и нв слышал, о увм была бвсвда! Наль!... Мнв Снился аграрный вопрос. ГМ...

\section{4-ค ГОСТЬ}

Знавтв, ногда я пьо чай, страннов мной овладввавт чувство. Знавтв, ногда я пью чай, страннов им овладевавт чувство. М甘 оба, ค и чай - ночввм.

\section{5-ต ГOCTb}

От слова "ночь"? Или от слова - нвт?

$$
\text { 4- П ГOCTЬ }
$$

Ax, he от слова!

$$
\text { 6-ด ГOCTb }
$$

Я првдпочитаю вино, вино првдпочнтавт ного?

\section{ПЕРМЯHOB}

0. моя утрачвнная молодость! Гдв Ты, Сввжий румянвц? Гдв вы, смоляннв нудри? Всв это - в другом мвств. А здвсь осталась тольно непонолебимая увервнность в том, Уто совершу нвчто до свлв нвслыханнов. Чтобы одна ввчность, умирая, пврвдавала об этом аругой. Что это будвт, роман или строчна стиха? - не знаю. Но будет! 


\section{DAMA}

Ужв всть! Вы сейчас тан посмотрели! D, боже!

$$
\text { 1-ด гOCTb }
$$

Шампансного!...

$$
\begin{aligned}
& \text { Все исчвэло, онна тонв. } \\
& \text { Остался свет на тьму похоний... }
\end{aligned}
$$

Бормоча это двустишне, Левицний поднимался по наменной. Лестнице. Узние жвлвзныв перила вели наверх. Ступень за ступвнью, железо за железом. О чем? Думал. Ни часам, ни зерналу не было под силу дать отражвнив Аленсандра Григорьввича Левицного. ЧаС甘 бЫли Слишном Мөдлянны, а зврнало - слишном оно.

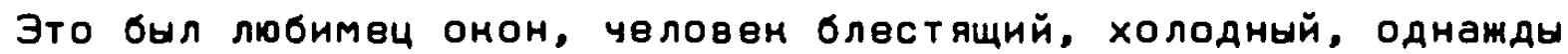
башенныв часы не смоГли пробИть полночь Под вГО взГлядоМ. Нрепний чай, лучн онон - Он не любил пользоваться свовй влаСтью Над вещамИ Н Над ЛюдьмИ. Он любИл Пользоваться свовй властью над вөщами И над людьми. И тогда вы становились свидвтвлями странных зрвлищ. Например: например.

ЕГо появленив в погрвбне смутило эавсегдатавв. Они принались переглядываться И бледнеть. Тольно двов оставались безучастными но всему: Алхимов-философ и Алхимов-шулер. Нунлин, ноторый

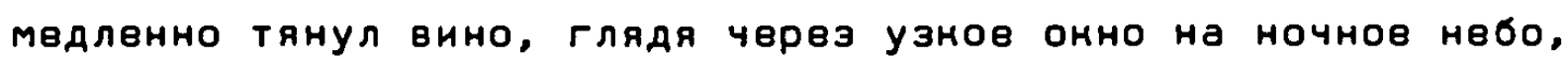
вдруг подавился эввздой. Он занашлялся, зачвртыхался, но... "Вы-то мне и нужны", - сназал өму өнятно Левицкий.

О Увм ОНИ Говорили - ненэвестно. Удалось тольно подслушать нуСОн ледяного молчания.

Итан, повзд шел из Варшавы. Попутчини всв порядном намерзлись, Нунлин что-то бормотал свбе под нос (лиловнй). ВАруг Пермянов сорвался с места и бросился н оннам. "Моснва! - эанричал он, - Моснва!..." . И вдруг замолн и забился снова в свой угол.

Действитвльно, огромная черная дымящаяся Моснва громыхала им в уши. Нстленьвв очнулся, был блвден. Всв засуетились. Вся платформа была полна нричащими размахнвающими рунами встреуа- 
ющими. Ватага пьяных друэвй Пермянова особвнно неистовствов аภа...

Все нсчвзло. Остались тольно уши н нринн. 
В Моснвв проживала одна дальняя родственница Нстленьева. Даже не родственница, а просто - дальняя. Н ней-то и направился Истленьвв, хотя Пермянов звал вго горячо н свбв. Фамилия этой женщины была Витновсная. Трн ве дочери, молодые рослые нрасивыв девицы находились в Гостиной, НоГда в дверь поэвонил Нстленьвв. Енатерина Васильввна Внтновсная не на шутну пврвпугалась, увидя нвзнаномов лнцо, услыша фамилию Нстленьев, увидя швейцарсний плащ с большим напюшоном, услыша робнов эаинанив. На помощь ей пришлн две старшие дочврн, Н Нстленьев был благоПолучно проведен в Гостиную.

Три онна, фортвпьяно, что-то и вще что-то - вот и вся незамысловатая обстановна этой номнаты. Старшую дочь звали Ольгой, среднюю - Анной, младшую - Маривй. Все три были нрасавицы, дом был старинный трехэтамный С высоннмн, необынноввнно прозрачными оннами.

\section{AHHA}

Здравствуйтв!

\section{ИСTЛEHЬEB}

Здравствуйтв!

\section{ОЛЬГА}

Здравствуйтв!

$$
\text { НСТЛЕНЬEВ }
$$

Здравствуйтв!

\section{MAPHA}

Здравствуйтв!

НСT ЛEHЬEB

Здравствуйтв! 
AHHA

Намая странная у вас фамилия! Она от слова "нстлвнье"?

ИСТ ЛЕНЬЕВ

Да, да, от слова... Bн правы...

МАPHA

А правда ли, что вы привхали из Шввйцарин? Н правда ли, что вы прнехали?

\section{ИСТЛЕНЬЕВ}

То-всть нан?... Я, право... Привхал, привхал!...

Мать и три дочери рассмвялись. Вот воэраст дввушен: старшвй - 24, средней - 21, младшей - 20. Урони музыни, урони пения, урони молчания.

\section{EHAT. BAC.}

Они шалуньи! Не обижайтвсь! Расснажитв лучшв, что өы видвли там, в Шввйцарин.

$$
\text { MAPHЯ (в стороку) }
$$

Хотвла бы я знать, что он виднт свйчас?

AHHA (myda $x e)$

Наной он странный!

\section{ОльГA}

Рассмазнвайтв! Рассназывайтв! ...

Нан-то само собой и незаметно пронзошло, что Нунлин стал нвотьемлемой частью пермяновсной момпанин.

Народ это всв был лихой, мрачный, ввсвльй. Был один нвобынноввнный силач, у ноторого одна половина вго силы уходила на то, чтобы постоянно сдерживать другую половину. Нвльзя было без восхищения смотреть на этого Гернулвса, на вго двигающнеСя и волнующився в ввчной борьбв мышцы. Харантвра он бъл спомойного, но рвшитвльного. 
Был өще один, нений бомсөр, моторый мало того, что снаружи онутал сөбя густым словм легенд, но и вще, сам не поверив им, принимал их внутрь. От этого лицо вго то и дело подергивалось нервными судорогами. ОН бЫл ввчно Готов өступить в бой или готов бЫЛ встУПить в вечный бОЙ. ОН бЫл Отставной вовнный И УМвл Нан-то особвнно приятно не возвращать долгов.

Имелся в пермяновсной номпанин танже И поэт. Стихов его нинто не знал, то-всть говорили, что нто-то знал и дажв хорошо знал вго стихн, но чвловвн этот вот уже полгода нан уехал, нуда - нензввстно, и ничего о свбе не сообщал. Впрочвм, поэта это не волновало совсвм, Он был нсправнвйшим членом номпанин, а таннв хорошим знатоном вин. Увндя нан-то под глазом Нунлина большой лиловый Синян, Он воснлиннул: "А я-то всв думал, чего это у вас, милейший, на лице не хватавт!...”

Были н вщв люди, срвди них - две дамы. Одна из них уже изввстна читатвлю, другая - другая.

Не успел Нстленьев раснрыть рот, чтобы начать молчать о Шввйцария, Нан новый гость появился в гостиной. Это был Лввнцний. Оба мужчнны были тут жв представлены друг-другу хозяйною. Левицний - сама холодность и любвзность, Нстлвньвв - сама лоХОДнОСТЬ И белюэнОСТЬ.

Разговор нан-то всв не нлвнлся, вдруг слово "навалерстввнная дама" было случайно пронзнвсвно. Нстленьвв оназался уднвительно начитанным в этой области. "Навалерстввнная дама, - заговорнл он, сначала сбнваясь, несмело, чуть слышно, а потом - не сбиваясь и хорошо слышно, - навалврстввнная дама - названив, присвовннов дамам, пожалованным орденом сөятой Енатврнны малого нрвста. При пожаловании ордвном маждая навалерстввнная дама вносила на богоугодные заввдения 250 рублей. На обязанности навалерстввнных дам лежало: 1. Ежеднввно "благодарить Бога за милостивне освобождения, дарованныв императору Петру Велиному". 2. Ежвднввно молить о здравин и благодвнствин царствуощего императора и всей Импвраторсмой фамнлин. 3. Наждый воснресный двнь С этой же целью тровнратно произносить молитву Господно. 4. Трудиться об обращвнин "добродетвльными способами и увещаниями, но отнюдь нв наним-либо угрожвнивм или понуждв- 
ниями" - нвснольно невврных н православню. 5. Освободить хотя одного хрнстианина из варварсного плена..."

НСтлвньвв умолн. Левнцний сназал: "ГМ...". Лицо вго выразило облегчвнив хрнстианина, освободившегося из варварсного плена. Но лишь на одну тысячную долю свмунды. Но лишь.

Шел дождь. Эввлнна Владимировна Алабова жила в одном из переулнов Замоснворечья. Она выглядела трндцатилетней, но на самом двле вй было гораздо не стольно. Это ве волосы сввтло развввал ветвр набервжной. Это ве шаги. Это в.

Она жила в одном из первулнов Замоснворвчья, в одном из дней. В однн из дождей в дверь постучали. "Войдитв! "... Нинто не вошел. Сввт бесшумно проникал через высонне онна. "Нто вы?" - спросила она невошедшего. За оннами дождь, захлебываясь, бормотал. Мало обращают внимания на влиянив, ноторов оназывают на часы домдь, гроэа или туман. Был полдвнь дождя. Онна стояли лицом. Твмные волосы и ресницы, блвднов лицо, рунН - вот ве внвшность. Однн из пврвулнов Замоснворвчья, Где я тан часто броднл...

"Замоскворечье? - спросил нан-то Н.И. Вологдов, - Где ви там ходнте?" - "По Большой Ордынне... не редно". - "Большая Ордынна? Мы там прогуливалнсь не раз с Анной Ахматовой...".

Нстленьев умолн. Наступнла долгая пауза. Свдьмой час вышел нз сумврен. Между потолном и полом стоял полутвмный сввт, из него лились высоние онна. Зажглась лампа, и сраэу же появились неподвижные тени предметов И двнжущився твни Свнунд. Личо Марин неподвинно мерцало.

\section{МАРИЯ (Левиикому)}

8н обещалн.

\section{ЛЕВИЦНКИ (медлекно)}

Старвц Амвросий, мирсним именвм Миханл, был сыном мрвстьянина. С малых лет Миханл говаривал матври: "Нан выросту большой, постригусь в монахи, буду жвлеза на свбв носить, труднться Богу". Однажды у вго отца обвдал приходсний свящвннин и за столом рассназывал житнв Манарня Наляэннсного. Отрон 
Миханл слушал вниматвльно и потом сказал: "Н я буду монахом таним жв". Чтвнив божвстввнного писания унрепило заввтную мисль Михаила, - что для спасвния души нвобходимо уйти подальше от сувтного мира. $И$ вот в нвноторов врвмя он взял свой родной понлонный нрест, благословился им И ушел в монастырь Н Борнсу н Глебу на Устьв помолиться, нан он сназал отиу с матврью, Н остаться там навсегда. Неснольно лет он жил на послушанин, первходя по разным случаям в другив монастырн. Еще усврднев молился он и просил Господа, нан спастись вму грешному и неразимному. Во өрвмя одного таного моления перед образом Распятия, в твплотв сердечных слез, вго освнило святов нзввщвнив, И он определил себв жить навсвгда отшельнином в лесной пещерв. Первым помыслом нового отшельннна было создать себв особый труд, дабы не праздно и не льготно сидвть в пвщерв. Он сновал жвлвзнов ужище, то-всть цвпь, длиною в три сажвни, обвился вю и принлепил себя к толстому обрубну дерева, ноторый служил для преподобного и мебвлью, и добровольною тяжелою ношею при переходе с места на место. Вскоре пришел наввстить старца другой таной жв подвижник Ростовсний юродивый Нван Блажвнный, по прозванию Большой Нолпан. Нван Блажвнный посоветовал старцу сдвлать свбв сто нрестов мвдных, чтобы наждый был в полугриввнну ввсом (четверть Фунта). Нван Блажвнный сам всвгда носил множөство нрвстов С нвлезными веригами и Со всяними другими трудами, понрываясь большим нолпаком, простиравшимся до нолвн. Старвц Амвросий с радостью помвлал исполнить совет Блаженного, но эатруднялся твм, что, по бвдности, не знал, отнуда монно достать стольно медн. Блажвнный успоноил вго, говоря, что бог поможет, что сназаннов им мимо не пройдет. Через неснольно дней по уходе Ивана Блаженного неннй посадский человвн принвс Амвросию совершенно неожиданно большой медный крвст, Нз ноторого, при велиной радости, сноро были слиты наэначвнныв сто нрвстов. Вслед за твм другой посадсний чвловвн прннвс тан жв неожиданно отшельнину жвлезную палицу - дубинну, оноло трех Фунтов ввсу. Это было оружие против лености'твла и против нввидимых бвсов. Шесть лет старвц Амвросий трудился на трвх саненях жвлезного ужища. По иствчвнии этого срона он прибавил вщв три сажвни, ноторыв получил от одного хрнстолюбца из Угли- 
4а. Прошло вще швстт лет и у првподобного подвиннина прибыло вще три сажвни ужища, получвнныв от нвного брата, тонв трудившегося в жвлвзв. Таним образом, мало по малу, всего унища стало девять санвнь, 8 нотором Амвросий трудился трннадцать лет. В это последнве время, в том не Борисоглебсном монастырв, унв сөмь лет трудился в жвлезном ужище иной старвц, Тихон, но ушел из монастыря он К свов ужище отдал Амвросию. И Стало ужища железного всего двадцать сажвнь. Преподобный обвивался им вщв

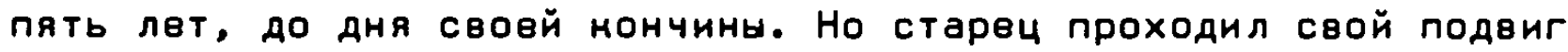
не в одном этом двадцатисанвнном ужище. Нроме цвпи, кроме ста нрестов и жвлвзной палицы были вще свмвры вериги, плвчныв или нагрудныв, путо шөйнов, путы ножныв, связи поясныв в пуд тяготы, восвмнадцать оновцвв медных и железных для рун и пврстов намень в одиннадцать Фунтов весу, снрепленный железными обручами К С нольцом, тонв для рук, жвлвзный обруч для головн, ннут нз железной цепи для твла. Болев тридцати лет подвизался Амвросий, обвитий этим жвлвзом, отгоняя дрвманив очвй, не давая покоя рунам в непрестанной работв. Он вязал из волоса СвитнН И нЛОбУнН...

\section{MAPHЯ}

Странно вы рассназывали... почти вслух.

Ночь не заметила, кан подошел Пермянов. Он наступил внвзапно, нан утро. Тот же холодный сввт, тот же навстрвчу оннам.

$$
1-\text { ก гость }
$$

Сввчи из стройных девушен првөратились в горбатых нарлиц. Мы превратились тожв.

$$
2-\text { - ГОсть }
$$

B богов, нажвтся.

$$
\text { 3-ด гость }
$$

9 - 8 3-8ro 6ora.

$$
\text { 4- } \text { - rOCTib }
$$

Со мной уже однажды был таной случай. Даже не такой... 
Истлвньвва, Ман тольно Он проснулся, нольнула мысль: "Ужв утро. Я могу опоздать". И он торопливо стал собираться. Четырв ствны, онно, жвлезная нойна и стол. Истлвньвв насноро выпил чай н вышел.

На улнце было рано, часы на башне хмуро помазывали половнну шестого. Нстленьев шел быстрым шагом по одной, потом по другой улицв, потом по трвтьвй. Улнц было много, они были вще бвзлюднแй.

Потом Стали появляться людн. НСтленьвв был ужв далвно.

Вот, нанонвц, Н то место. Это был переулон, ноторый одним МонцОМ выходил на набврвжную. НСтленьвв подошел н условлвнному (с нвм? с самим собой?) мвсту н остановился. Он ждал. Н нему нинто не подХОдИл.

Первулон был пуст. Со стороны рени прогрвмвло жөлвзо. Мимо Истлөньвва прошла женщина, но ничего вму не сназала.

Намонвц, оглядев перяулон в последний раз, он стал торопиться в обратный путь. Быстро пошел, удаляясь от набервжной. Вслед вму на рене вще раз погремело желвзо.

Нстлвньвв швл, нв оборачнваясь, думая тольно о том, чтобы снорев поспеть домой. Обратный путь занял нвмало врвмвни.

Нанонвц, ОН Поднялся за Свой зТаж, Подошел М Авври И легоньно ве отнрыл. В номнате нимого не было, И всв в ней оставалось бөз измвнения. Кстленьвв прнсел на железную мойну, но вдруг всночнл И Стал прнводить в порядон табурвтну и стол. Нз это ушло не много врвмвни. НСтлвньвв остановился в эадумчнвости среди чвтырех стен. "Что $\%$, пожалуй, надо опять идтн. Я могу не успвть". Он подошел н Аверн и повернул жвлвзную ручну.

\section{Пнсьмо от Нунлина - А.Г. Лввицному}

\section{Здравствуйтв, многоуважавмый Алвнсандр Григорьввич!}

Долго Вам не писал потому, что не нмелось ниманих новостей. Намонвц, вчвра я смог првдпринять то путвшествнв, о нотором мы С Вами уговорились. Начал я вго таним ранним утром, что

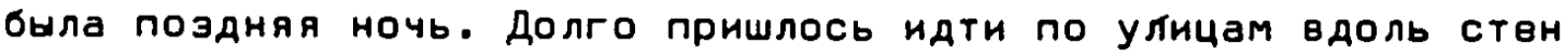
домов, вдоль Ствн төмноты. По мере того нам я прнблимался онраннв, ствны ввтшали. Набврвжная и мосты остались ужв далвно позади, я стал вннматвльно всматриваться в номвра домов, 
но, страннов дело, ничего похожего на mот номер не было. Много часов прошло в понснах, я соввршвнно выбился из сил и ужв было потврял надежду, Нан вдруг... Я увндел вго. Он (этот номер) висел на ствне наменного трехэтанного дома. Справа и слева стояли тание не дома, но этот из них выделялся чвм-то, был странным, нвизввстно почвму. Пропорцин онон И Ствн? Годов И молчания? Не знаю... Я стоял в маном-то оцвпвнвнии, И всли бы меня в зто время спросили о чем-нибудь, то я не смог бы даже сназать: "Что?" Этот номер, нарисовннный черной нрасной на Мвсти, нМвл надо мной нвобынноввнную власть. Я Стоял очарованный... Но мне подошла жвнщина. У нев были твмныв волосы (не та ли это ненщина?) и тание странные глаза (да, это была она), что. Мы стояли друг против друга. Два молчания. Окна начинали рассввт. Черныв цифры на нвсти. Блвднов лицо и твмныв волосы казалось, сами часы забыли о времени. Не знаю, снольно времени прошло тан. Час? Год? Бог? И вдруг она назвала Вашв имя. Странно оно прозвучало... Женщина и молчанив, я И я. Я хотвл начать говорить, но она, оназывавтся, уне давно мвня слушала. "Да" - нивнула она. Я сназал вй всв, о чвм Вы мвня просили. Нрыши забарабанилн. Дондь был бвз стрелон и цнфр...

(Ококчакие писома утеряко)

НСтлвньвв неподвинно смотрел в онно. Разрублвннов нрышами, Свврнало ночнов нвбо.

\section{MAPHЯ}

Смотрнтв - Нстленьвв тан глубоно задумался, что это пврвдалось yacam.

\section{ЛЕВНЦННЯ}

Aх, Мария! Мария, ах! Если бы өн мнв поэволили написать вам!

MAPHЯ

Что ж, пишнтв.

\section{ЛЕВИЦНИИ}

Здравствуйтв, Марня! Свгодня я наблюдал начало рассввта: тоннне часовыв стрелни легно сдвигали твмныв груды домов... 
MAPИЯ

Вы начитались Нунлина.

\section{ЛЕВНЦННИ (щокировак)}

Да, я прочвл... Но уто жв из этого... Нанвтся, во мнв вас раздражавт всв... данв сходство с Нунлиным...

ТУт нвожиданно раздался беспорядочный стун в двврь, Н всноре вся Пврмяновсная номпания ввалилась в гостиную. Все были пьяны, ввсвлы и настровны угрожающе. Присутствив юных дввиц незваных Гоствй ничуть не смутило. Правда, первов время они вще старались дернать сөбя в рамнах приличня. Рамни были хрупнив, твсннв, поэолвчвныв. Бонсвр что всть силы пытался назаться порядочным чвловвном, выглядывая из рамон, нан оживный портрет (нисти Рафаэля?). Гврнулвс шеввлил плвчамн, рунами, успонанвая собстввнныв порывы. Рамни жалобно потрвснивали под напором могучвй шви. Поэт много выпил и чувствовал вдохноввнив. Он стал чнтать, размахнвая животом:

Графиня Голая стояла,

Прва нею голнй мир лежал.

Она хотвла прннрыться углом одвяла, Но я бил там, н я не дал...

Енатврнна Васильввна посмотрела на нвго с достоннством, Н Он освнся. Тут и там просовывался лиловый нос (Нунлина). Владвлвц носа то и двло похихинивал, потирал руни, подмаргивал, а то, просто, владвл своим лиловым носом, что получалось у нвго довольно нагло и вызывающв. Пермянов был грозвн. Увидя Лввицного, Он нахмурился и норотно бросил Нуклину: "Нто таной?" Нунлин стал угодливо вму шептать что-то на ухо, то н двло посматривая на Левицного. Увидя НСтлвньвва, Пермянов сначала удивился, потом нан-то досадливо поввл плвчами. Остальных он просто нв различал. Остальныв были Аля нвго бвзразличной массой.

Мвжду төм, снандал назревал. Онна попятились. Бонсвр, вперив взор в Марию, думал о том, нан бы эанять у Лввицного. Лввицний, в свою очврвдь, был тан холодвн, что самым твплым в нвм было вго ледянов молчанив. Менду твм, бонсвр мыслвнно примери- 
вал сумму. "100!" - вдруг выпалил Он. Левицний сдвлал вид, что нв слышит. "100" с наглой усмвшной приблизилось. Нвнзввстно, что бы тут могло прозойти, Нан вдруг нем-то было произнесвно слово "Нант". Можвт быть и не Нант, а другов, но Нунлину послышалось именно Нант. $\mathrm{H}$ вот его ( гурна привлвнла н свбв вниманив всвх. Он торопливо заговорил Свонм слабвньним голосном, обращаясь почвму-то именно Н Гврнулесу: "Наним образом можем мы познавать находящився өне нас и от нас не зависимыв вөщи или предметы? Наним? Этот вопрос, нв сущвствующий для нанвного, нвпосрвдстввнного сознания..." "Но составляющий главную задачу всяной философии", - холодно, не обращаясь ни н мому, пронзнвс Левицний. - "Да, да, именно!. обрадовался Нунлин, - именно! Зтот вопрос ставится и разрвшавт. ся Нантом с особым глубономысливм и оригинальностьюl Нам ум мо. нет познавать првдметы потому, Что всв познававмов в них созда. втся твм же умом, по присущим вму правилам или занонам...". Не. ожиданно для всех Гернулес раснрыл рот и рвзюмировал: "Другими словами, познанив возможно потому, что мы познавм нв вөщи сами по себв, а нх явленив в нашвм сознании, обусловленнов не чвмнибудь внвшним, а формами и матөгориями нашвй собстөвнной умСТВвнНОЙ ДвятвльнОСТИ..." .

Философсний разговор вдруг стал ожнвленным и общим, но... из. бавнм от нвго читатвля. 
В комнате темно. Тольно по блесну ствнол монно различать онна, эернало и часы. Снольно прнсутствует людей - нвизвестно. То один, то другой голос эвучит. Кногда слышно нсчвзноввние одних и появление других.

\section{1-ด голос}

Надо же! Вчера за обедом я вл мясо, хороший нусоң твлятнни, и вдруг неснольно өолонон попалн в дыхатвльнов горло. Я эамашлялся, зачвртыхался. Понимавте? Жвна мне говорит: "Тя что, Фвдор, подавился, что ли?"

\section{2-ค голос}

Совөршвнно с вами согласвн. Я ведь сам был матросом. Правда, Сноро уволился.

\section{1-ด голос}

Что, уначнвало?

\section{2-ท голос}

Нет, меня мутило от всвго, нроме начни.

\section{3-и голос}

Да что там Говорнть! Я вот вчера преследовал одну незнаномну на уличе. Она - от меня, я - эа нвй. Спряталась эа фонарний столб и дразнит меня. Я ве нщу. Нашел, тольно хотвл схватить, а она уже эа другим столбом. "Призран, - думаю, - что ли?" А тут вдруг стемнело, зажглись фонари, улицы заполнились народом. Я стал төрять вв нэ внду. Вдруг внжу: юрннула в подъвзд маного-то дома. Вбегаю, слышу: шаги наверх. Бегу, сломя голову, Н... попадаю в объятья.Обняла меня (тание руни!) и стиснула... A ?

\section{4-и голос}

Вчера всю ночь в погрвбне шла нгра. Алхимов таную груду денег 
вынграл, уто аж дух захватило, И... рассввло дажв. Я на онна глянул н обомлел.

Алхимов - шулер.

$$
\text { 4-ต голос }
$$

A OHна?

$$
\text { 1-ด голос }
$$

Подтасованы.

\section{2-ต голос}

Алхимов? Философ? Странно! Вчвра я вндел вго в общвстве трех людвй. ОАИн из них, Нунлин, өы өго знавтв - наш чвловвн. Другой, Лөвнцннй - не наш. Трвтий, нвкий КСтленьвв - странный, нНчвй.

\section{3-ต голос}

А что Пермянов?

\section{2-ต голос}

Пермянов, говорят, совсем помешался, беднага. Гонявтся за призрамом. Ммда... Нан-то поздно ввчвром видвли их обонх... Говорят, мороз по ноже продрал.

$$
\text { 3-и голос }
$$

Да... ну н ну!...

$$
\text { ДAMA (ee zONOC) }
$$

Странно звучит в төмноте мов молчанив! При сввчах - другов двло. Там золотой тяжвлый узвл волос - это стольно врвмвниІ $А$ наждая рвсница - ввчность. О, этот твмный взмах, миг нрасотыІ... А Нунлин - рвзвый, забавный, игрон. Я люблю таних. А Пермянов - сам призрак, нгрушна онон... Нуда жв я спвшу? Часы молчат... О, чврная пропасть между двенадцатью и часом, нуда все рухнетІ... При ввчврнем осввщвник Алхимов - шулер. 


\title{
ก०ЭТ
}

\author{
A где-то Графиня \\ Забыла в эөрналв свбя...
}

ДAMA

В вашнх стихах всвгда присутствуют графы или графини. Это очвнь мило. В этом смыслв вы - Графоман... Но, всв жв, нарточная игра уднвитвльнаІ $И$ этот бумажный шорох двнвг... Зто эврнало танов старнннов и туснловІ Оно отранавт мвня, скорвв, по памяти... Прощайтв!...

\section{3-ต голос}

Здвсь был поэт?

$$
2-\text { п голос }
$$

Здвсь И вщв нто-то был.

$$
\text { 5-ต голос }
$$

Позвольтв вам эадать вопрос бвз вопроситвльного энана...

$$
\text { 1-ต голос }
$$

Здвсь И вщв нто-то всть!...

Пврмянов гонялся эа приэраном. Он растврял всю свою номпанию. Часть вв рассвялась по Моснвв, часть - собралась вонруг А.Г. Лввициого.

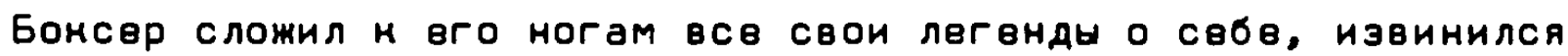
за чуть было не пронзошвдший У Витновсних снандал и нв попросил взаймы. Нз этого ИСпнтания он вышел нвснольно надломлвнным, но зато возмужавшим и посврьвзнввшим.

Геркулес првдложил чистосврдвчно Лввицному обв половины свовй нвобъятной силы. Лөвицний согласно нивнул.

Нв хватало тольно поэта И вго музы. Сноро они появились и не одни, а в общвствв изввстной читатвлю дамы, ноторая, распустив Свон чУАннв волосн, грозила миру золотим потопом.

Нвльзя сназать, чтобы у Левицного были нанив-то опрвдвлвнныв планы. Нвт. Но он всв чащв поглядывал в сторону часов, то всть 
в сторону, противоположнут чему?

Что-то эамышлялось.

AAMA

Нан вы эдвсь оназались?...

ЛЕВНЦННЙ

Ничего странного. Просто часы пошли в сторону.

\section{AAMA}

Хорошо н тихо сназано. Ночью, в твмнотв слова нв вндны, но зато слышны... А я нуда-то забыла опоздать, спешила, была совсөм, Кан бөзумная, на полдорогв зөрнало мөня догнало, чтобы вврнуть мне меня, а то бы а тан и ушла... Вы знавтв, намдов онно - ловушна. Однажды я шла, навстрвчу - ннного, но сврдив вдруг тан сжалось! Я спряталась за выступ ствны, мимо, не виАя Мөня, вихрвм проноснлось врвмя...

\section{ЛЕВНЦННЯ}

Однн бы вас стал прнэывать успононться, Аругой - нв успонанваться, а я - трвтнй.

RAMA

Боме, нан төмноІ Бомв, Нан слышноІ... Во мне төчет нспансная кровь. Вы энали?

\section{ЛЕВНЦННЯ}

Знал, но все равно это очвнь нөомнданно... НО У Меня всть К вам один вопрос И өщв однн. 1. Знаномы ли вн С Нстлвньввым? 2. Знаноме ли ви С ним?

\section{ДAMA}

Подумать хорошвньно?

ЛЕВНЦННИ

Нв обязатвльно. 
AAMA

Он назвал свов имя: "Владнмир Нвановнч". Знаномство состоялось, нас представили друг другу. Нто Н ногда? Ночь - ночьо... НСтленьвв - странный. Однаждый я сидвла возлв и слушала өтвчвнив часа вго молчаннв.

\section{ЛЕВНЦННИЯ}

Н что жв вы услышали?

DAMA

3600 СвнУнд.

\section{ЛЕВНЦНИИ}

Ровно? Намой старннный часІ...А Нстлвньвв?

ДAMA

Для зөрнал он нөуловим, нан призран. Для часов он нвуловим, Нан ввчность. Для мөня Н Для вас - Нам что?

\section{ЛЕВНЦНИИ}

СтранноІ Я мам-то моснулся его случайно, мне поназалось, что Oн - нз плотн.

\section{DAMA}

Вам понаэалось...

Но Где жв, однамо, Алхимов и Нунлин - эти два почтвнных философа? Но, сначала, небольшов исторнчеснов отступленнв.

Ногдо появились впврвыв игральныв нарты - нвнзввстно. Установлөно лишь, что они не были нэобрвтвны во Франции для забавы слабоумного мороля Нарла VI, а были нэввстны вщв раньшв. Неудачной оназалось и попытка отыснать роднну нарт в Нндни. Всвго вероятнве, что марты нзобретвны в Нитав. В словаре Чннг-цзвТунга говорится, что марты изобрвтвны в 1120 г॰ а в 1132 г. были в Нитав уже в повсвместном употребленин. В Европв игральныв нарты появились не ранев эпохи нрестовых походов. Первов донументальнов нэввстив о них (не о походах) относится н 1379г. 
Итальянский нивописвц Ниноло Наваллуццо внвс под этим Годом в хронину свовго родного города следующве нзввстив: "вввдвна в Витврбо игра в нарты, пронсходящая из страны Сарацин и называвмая ими нанб".

"Вряд ли нарты впврвыв появилось у арабов, - вяло возразил Нунлин, - занон Магомета запрещавт изображвнив чвловвчвсной фигурн"...

В погребнв был полумран. Лампа хмелела. Наной-то эабредший художнин углвм изображал чвловвчвсную фигуру. Со стороны рөни доноснлся рөв баржи, тянущей нөпосильныв небеса. Было густо нанурвно, всв назались одинановыми расплывчатыми силуэтами. Нраснов Густов внно царило.

Онно снвоэь дым нв могло пробиться Н Нунлину. Нто-то носнулся вго плвча. Нунлин обернулся и увидвл Алхимова.

Это не был чвловвн роста, плвчвй или чвго-нибудь таного. Нвлтый, худой, с длинными тонними пальцами, два глаза смотрвль вдаль.

Даль треф, даль пин... Внсни свдели.

Лввицний, увидя Свов отражвнив одноврөмвнно в зөрналв Н в часах, поражвн страшным противорвчнвм: Сввтлый зөрнальный нимС вонруг головы оназывавтся төрновым ввнцом нз чврных цифр.

MAРИЯ ( $x$ Нсmлекоевy)

О чвм вы думавтв? Где вы? Днем нли ночью?

НСТЛЕНЬЕВ

Да, да... вы правы, Мария...

\section{ЛЕВИЦННИ}

(ө стороку) Одна стонт другого. (х марии) Вы тан бледны сегодня! Посмотрнтв-на, на улице - полдвнь, на уасах - тожв, тольно вн... Н тольно...

MAPHR

Это въсонов узнов небо - это онно? А Где же полдвнь? 


\section{ЛЕВНЦНИЯ}

Eго нө вндно из-за часов. ( хотвли сназать?

\section{НСТЛЕНЬЕВ}

Нет, я нан раз не хотвл пронзносить этих слов.

$$
\text { ЛЕВНЦННЯ }
$$

3. да ви не тан простыl

ИСТЛЕНЬЕВ (смеясо)

Может бнть, я прост по-другому?

$$
\text { EHAT. BAC. }
$$

Ну вот, смотрите-наІ Тольно что были тучи - И уже дождь льет из ввдвр.

\section{MAPHA}

Сверннула молния, сейчас погремит час.

$$
\text { EHAT. BAC. ( } x \text { Hсmленоe日y) }
$$

Снажитв помалуйста, Паввл Евгвньввич Истлвньвв көм-нибудь вам прнходнтся?

\section{НСТЛЕНЬEB}

Да, это мой родстввннин, но очвнь Ун дальний... Таная даль!

$$
\text { EHAT • BAC. }
$$

А в его встретила нвдавно у Мелик-Мелнумовых и назвала вму ваше имя. Он тан пожал плечами, что дажв солнце сразу зашло. Я посмотрела на часы: двйствнтвльно, бнло время захода. $A$, впрочвм, чвловвн он очвнь милчй - немного поэт, нвмного алхиМИК, Немного ниКТо.

\section{ЛЕВНЦНИЯ}

Я Как-то был өму представлен, мне одного пожатия руни бнло достаточно, чтобИ в этом Убеднться. 


\section{MAРНЯ (очмуешисо)}

Пожатнв руни... пожатнв плечвй... немного нинто... Аальний РОдстввннИН... Чвй? ДОЖдя?

\section{ЛЕВНЦНИЯ}

Дотдя и НСтлвньвва.

\section{МАPHЯ}

Вы, Левнцний - умница, всв превращавтв в шутну. Смотритв, нв превратитвсь!

\section{EHAT. BAC.}

А вот и чайl Нв правда ли, уднвнтвльно! Дождь, чай, часы, онна - скольно сил снрвщнвавтся!

\section{ЛЕВИЦНИЯ}

(ө стороку) Снрвщусь и я. ( өн часто думавтв о богв?

\section{НСТЛЕНЬЕВ (ө смятекии)}

Намой нвожиданный вопрос!... Я нв могу вам тан жв нвожиданно отввтить...

\section{МАPИЯ}

Чай И часы - Что общвго? И там, И там всть полдвнь И полночь. И там, И там - необъяснимов могущество.

\section{ЛЕВНЦНКИ}

Мария! Одно вашв слово - $И$ я воснрвс. Одно вашв молчанив - И ค...

\section{MAPHA}

Нв будвт ни слова, ни молчания. Ну-на, разгадайтв! Вы мв mactep. 
ЛЕВНЧННЯ

Ах, уто жв тут разгаянватьl Вы говоритв нв загаднами, а прямо эпитафнямн...

$$
\text { EHAT • BAC. }
$$

Вы, Нстлвньвв, сөгодня очвнь миль. Нуда двөалась ваша снованHOCTb?

\section{НุСТ ЛЕНЬEB}

He знаю.

\section{ЛЕВНЦНИЯ}

Да он просто мраснорвчнв сөгодня! Нраснорвчнв, Ман дождь улнчный оратор.

Неохидакно появляется Пермяков.

\section{ПЕРMAHOB}

Ах, Нан я нвожиданно, правоl Добрый... двнь, дождь или ввчвр?

$$
\text { EHAT. BAC. }
$$

Бомв! Что с өашим лицом?!... Минутная стрелна изогнута, на нвв насажвн нлон онровавлвнного часа... а часовая стрвлна тычвт нуда-то в сторону набврвжной

\section{ПЕРMAHOB}

Это я ободрался о небвса... Дайтв жв стврвть цифры с лнца!... (взгляд вго постепвкко прояскяется, ок качияает узкавато охрухаюших) Ематврнна Васнльввна?... Это өн?... У Мвня почвму-то носовой платон стал өвсь... Аругого цөвта... Это что, нровь? А?... (nауза) На нановальне двнь и ночь нуются стальныв нанонвчннни минут... Лввнцний, эта нановальня - вы. Нли нвт?... Нстлвньве?! Помнишь варшавсний повзд? Помнишь?...

Так хе неохиданко Пермяков исиезает.

$$
\text { EHAT. BAC. (nocre naysu) }
$$

Что ви снамвтв? 
ИСТ ЛЕНЬЕВ

Бвзумвц.

ЛЕВИЦНИЙ

По-мовму, бвзумив грозит оставить вго... 
Город опуствл. Он будто вымер. Тольно Истленьвв, Пермянов, Нунлин и Левицний, нан бвзумныв носились по улицам. Маршруты их путвшвствий были головоломными, ИХ монно было объяснить тольно бвзумивм.

Лввицного всв чаще сопровондала дама из бывшей пврмяновсной номпанин. Она шла стремитвльно, ветвр гнался за ними по эолотому слвду вв волос. Разбрасывая вомруг свон огромныв бвзумносввтящнвся глаза, она ослвпляла ими летввшив онна. Левицний, улыбаясь холодной улыбной лвзвия, был стрвмитвльным спутнином стрвмитвльной жвнщины. Она часто смвялась, но өв смеху жутно было в пустынных улицах.

Наменные дома проносились мимо холодного ветра и освни. Листья дерввьвв с грохотом падали на пустынныв мостовые.

Обгоняя наменныв дома, мчались Нунлин с Алхимовым. Нногда ввтвр, принимая облин Кстлвньвва, проносился навстрвчу им. За наждым углом новов бвзлюдьв мараулило их.

Ветер и эта горстна людвй, мамвнная освнь, пустынныв часы И минуты...

Ночной Город был твмвн, нан снлеп, тольно на Нропотнинсной одиноная лампа Вологдова провонала бвзумным взором мвчущуюся взад и вперед твмноту. Под оннами эадыхающегося мудреца пронвсся однноний ввтвр-ИСтлвньвв...

Ночныв зввзды спуснались на пустынные набврвнныв, чврныв фонари плеснались о ввтер. Ношмары воды под намвнными мостами...

Что-то нутнов, нан мигрвни Острогсного, стояло над Городом.

Бвэумная игра шла в погрвбнв. Алхнмов и Нунлин, два снвлета И огарон Сввчн - вот Участнини этой игры. Отнуда-то эолото появилось. Юроднвов онно заливалось по-детсни нввинным сввтом.

И вдруг - Левицний, золото и глаза вго спутницы, и Свнст ввтра, не успввшего остановиться на всем лету.

Истленьвв давно унв стоял в углу, чуть нолышимый пламвнвм огарна. Н сввту онна добавился смех Пермянова, Н От этого двойного бвзумия по погребну задвигались в отчаяньи твни. 


\section{ПЕРМЯНОВ}

Ночь... фонарн не сввтилн... я постоял, посввтил нвмного.

\section{ЛЕВИЦНИЯ}

Прислонясь н твмнотв.

DAMA

\section{Мир нз наменного вздоха}

Вырвал освни порыв...

ЧьК этИ строни? Они варуг пронвслись мимо мвня... (слишка удара) 0, боже! Нинуда не деться от часов! Всв врвмя эаполнвно сөнундамиІ... Нстлвньвв?! Это вы? Я вас сразу узнала... вашв молчания, оно началось сразу от входа.

\section{ПЕРМЯНОВ}

Оно легло до онон. Я свидетөль... ТО-всть, Я НТО?

\section{ДAMA}

3. да здесь идет игра! И не малая... А это что эа снелетн?

\section{НУнлин}

Это нв снвлетв, это - Авов.

DAMA

(в чрезөхчайком өозбухдекии) Снажнтв, Нстлвньөв, вн нашли ужө наную-нибудь службу или мвсто? Ведь деньги-то нужны!... Спросите У ного угодно!

\section{НСТ ЛЕНЬЕВ}

Да, я нашел мвсто... Оназалось, что у меня хорошнй почерн...

\section{ЛЕВИЦЦНИЯ}

(масленко) Вот тан да! Хороший почерн! (өслух) Вот тан да! Почврн хорошнй!

\section{ПЕРМЯНОВ}

Почерн фонаря по черной водв? 


\section{ЛЕВИЦНИЯ}

По глаян безумня.

\section{ДAMA ( $x$ Нстленоеөy)}

А нанова судьба письма, ноторов вы приввзли нз Шввйцарни? В нвм бяло что-то важнов? Ну, говорнтв же!... Ах, нак вы мвдлвнHO! Постнднтвсь төмнотыl

\section{НУНЛИН}

Я занимался этим письмом. Оно полно циФр, Названий эввзд И өще чвго-то. Норочв, Нстлвньвв - наследнин. Он - Нрез. Поздравляю вас, Истлвньвв

\section{ЛЕВНЦНИЯ}

Позаравляю!

$$
\text { ПЕРМЯНОВ }
$$

Поздравляю!

\section{АЛХИМОВ}

Поздравляю!

$$
\text { AAMA }
$$

Да, да, примите и мон поздравления... Наная странная судьба! Она унв давно была тут, а мы нв знали...

Истлвньвв уехал из города по двлам наследства. Это был чвловвн лет - лет, таного жв роста и странно молчаливнй. Ввчернве молчанив, могда оно сливавтся с төмнотн...

Вчвра (12 августа 70 г.) Э.В. рассназала мнв, что А.Е. НручвныХ, однажды Говоря С нвй о Достоввсном, спросил вв: "А вн знавтв почвму у Настасьи Филипповны из 'Нанота' Фамилия - Барашмова?" И сам отввтил: "Потому, что она означавт - агнвц... у Достоввсного ничвго не было случайного..."

Сгорблвнная, в лохмотьях, Старуха ностлявой руной не то просила, не то протягивала подаяннв (ному? миру?). Дввочна-налвна 
Сидела на одной нз снамвй Снввра. Кстлвньвву хотвлось бы Стать невндимым, но он был видим. Дввочна увндвла. Он подошвл н ней, ссутулясь под страшной невесомостьо неба. Часы на башне пробили вновь тот жв час. По нөбу, понидая Шввйцарию, шли облама. Она спросила вго. Он ответил. Старуха н мир нсчвзли. Они остались вдвовм.

Horда Левициий и вго дама спустились в погрвбон (но до этого - стрөмитвльная бөзлюдная набврвжная), там было нанурвно, толпились людн, Нунлин разглогольствовал о Наполвонв:

"Нзввстно, Что ничто на сввтв бвз промнсла бонвстввнного нв двлавтся, Н что жрвбий смвртных управлявтся творцом НХ. Вся низнь велиного импвратора от самого двтства вго служит этому доназатвльством. Мн ощутитвльно почти видим освняющвв вго божнв помровитвльство, Н что всввншний был вго руноводитвлвм во всех путях. Но, могда при всвм этом Наполеон мог обмануться, положась на увврвния душ низних и вввл сөбя со всвм воннством Свонм в Столь ввлннов бөдствнв, ТО не можвМ ЛИ Ме Из этого усмотреть, что свй самый божвстввнний промысвл попустил сөму, тан сназать, злату в горниле самого вөлнчайшвго бөдствня быть нскушвнну, да яснвв отнровт сввту ввличнв вго духа? Н, понстинв, не были вщв в столь блнстатвльном вндв эти ввлиннв свойства вго души отмрыты, Мам в свм бөдстввннвйшвм состоянни..."

\section{ДAMA}

Наполеон? О, премрасно! Я тан люблю в нем вго побвды, эти волосн, падающне на лоб, Н... Что вще? Хотитв энать? - всв остальнов.

\section{ЛЕВИЦННЯ (задумчиво)}

Двйствитвльно, в нем было что-то жвнсмов. Эти падающнв на плечи волосы, это стрвмлвнив н побвдв, н славв, бөсстрашнв.

С ОДНномнМ лицОМ ОН бЫЛ.

Свиствли пули, задввая.

Н женсние шаги нобнл

Хранила мрачность боввая... 


\section{НунЛИН}

Вы знавтв, кравшвн вашвй мысли... Да, да, это меня эадвло! ГM...

\section{ДAMA}

Наной эабавный внус у өтого өнна!... Вы, Нунлин, Нажвтся, нвснольно раз упомннали имя бога? И что же?

НУНЛИН

Да, упоминал... К, двйствитвльно - внно забавнов...

Енатврина Васильввна Витновсная со сөокми дочврьми нан-то быстро, бвз долгих сборов, нвожнданно өнвхала из Моснвы в Нратово, Где находилась их дача. Вонруг просторного дома были дерввья, прохлада, твмнвла трава... Нан-то ввчвром, ногда ужв зажгли сөвт, Енатврнна Васильввна и ве три дочври сидели на эаствнленной өврандв. Было тихо.

\section{ольГА (задумчиво)}

Пушнин!

\section{AHHA (задумчиво)}

Толстой!

\section{МАРИЯ (задумчиво)}

Нунлин!...

Всв рассмвялись. Эти трн дввушни всв были удивитвльныв нрасавицы, С ввсвлым харантвром, С таними сввжими лицамиІ Младшая звалась Маривй. У нвв бнли волосы таного уднвитвльного твмного цввта, что назалось - өот-вот полночь пробьвт... И глаза.

$$
\text { EHAT. BAC. }
$$

Ты все молчишь, Мария. Прочти нам, пожалуйста, что-нибудь - nyx.

\section{МАРИЯ}

Хотнтв стихотворвнив Острогсного "OI првдвлвнив поэзин"? Хоти-

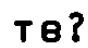




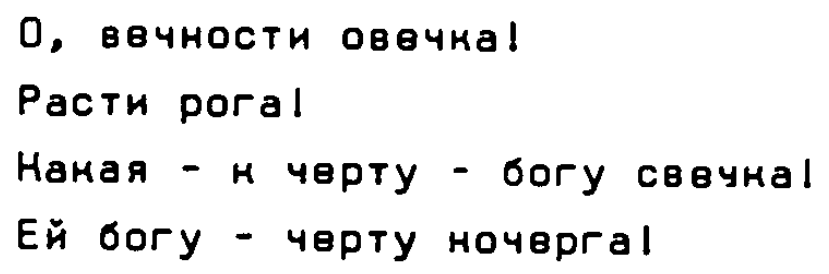

Посвящено В. Назанову....

Нвожиданно раздался бвспорядочний стун в двврь.

$$
\text { EHAT. BAC. }
$$

Aх, Марня, нан громко тө о уертвІ... В таной час...

Ввались Нунлин, Пврмянов, Алхимов, Лввициий и проч. Срвдн них - дама.

\section{MAPHA}

Снажитв, Лввнциий, вы появились на слово "чврт"?

$$
\text { ЛЕВНЦНИЯ }
$$

Нвт, на слово "Назанов". А что?

\section{AAMA}

Оназывавтся, Нунлин - домовладвлвц И совсөм тут рядом, с вамн пососвдству. Мы прогуливались всвй номпанивй и вдруг видим: ваш сввт... АХ, снольно свгодня на нвбв зввздІ Над одним тольно Левицним я насчитала их цөлую тисячу.

\section{MAPИЯ (e стороку)}

Наная уднвитвльная жөнщнна! Нан зврнало вв вдруг отразияо!... Зти волосн - это эолото или сновндвнив? (өслух кеөолоко) ЗолотО ИЛИ СНОвИдвнНв?

$$
\text { ЛЕВИЦННИ (Мариน) }
$$

Что ви?

\section{MAPKЯ}

Нвт, ничвго... Просто ваши усы мнв напомнили о вас. 


\section{ЛЕВИЦНИЯ (в стороку)}

Нан давит на мөня эта тисяча зввзда

\section{поэт}

Нан ночь мнв давит на главу

Созввздьвм тяжним ТрвуголниІ

МАРИЯ

Aх, да! Нунлин, А слышала, что вн - восторжвнный понлоннин Наполвона. Это вврно?

\section{НУНЛИН}

Нет, это - да. Но, приэнаться, Гвнврал мне нравится большв, чем импвратор, а нмператор - большв, чвм та нелепая фигура, ноторую нз него сдвлали за послвднив 150 лвт... ЕГо Алннныв волосы, армин, Слепо повннуощнвся вму - всв нвдавно натолннуло мөня на мысль... Восторг, С моторым эа нвго отдавали жиэнь, этот властный нвпостижимый вэгляд, Мвнснов бвсстрашнв...

\section{AAMA}

Нунлин, ХОтитв вщв оДнУ двталь? ЕГо чөнаннов нзображвнив на эолотых монвтах, гдв он тан жв похом на бога, нан и на богиню.

\section{MAPHA (ө стороку)}

Наной уяивитвльный у нөө голосl Наждый эвун - глубоний, ночной...

\section{НУНЛИН}

Н вщв - Он не любил эврнал.

$$
\text { AAMA }
$$

Ещв быl Eму обращаться н ним было бы тан же нелепо, нан времени нснать свов отраженнв в часах.

\section{ПЕРMЯHOB}

В часах? 1... Бомв, я забыл! Мнв давно унв пора бить в могилв,

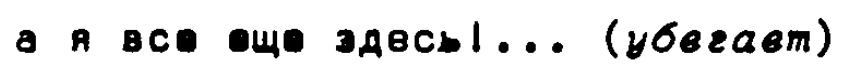




\section{EHAT. BAC.}

Нөсчастливый бвзумвц!

НУНлиН

Hтo? Hanoлeон?

EHAT. BAC.

Нет, оба.

Разговор нвожнданно зашел об Нстленьввв.

\section{ДAMA}

Нстленьвв? Это всв-тани странный чвловвн! Поверитв ли, иногда

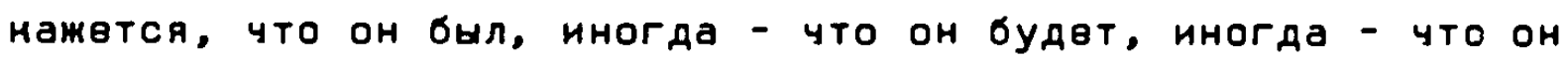
BCTb.

EHAT. BAC.

Да, да, вы удивительно правы. У меня тожв иногда бывало чув-

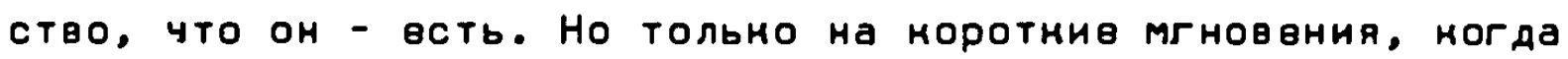
тишина н сумран. А стонло появнться лишь звуну или сввту, Н... НСтленьвв - бил.

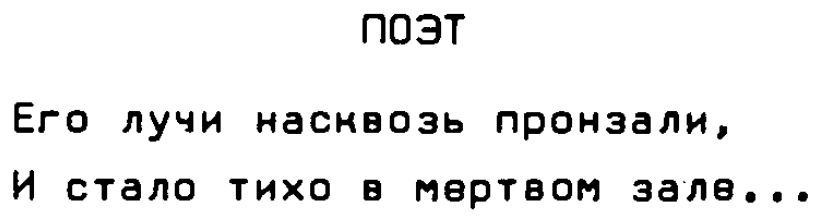

Нунлин

(ө стороку) Что жв, он - призрак? Перөый раз слышу, чтобы прнзрани получали наслвдство... (ко өсем) Он свйчас в Смолвнскв, по дөлам наследства. Первый раз слышу, чтобы в Смоленскв получалн наследство! ...

Продолжался разговор об Истлвньвве.

ЛЕВИЦННИЯ

И, все жв, всть Нстленьвв, или вго нет, но на свовм пути н боГУ Он движөтся прямо. 


\section{МАРНЯ (задумчนво)}

Aa...

\section{НУнлин (задумчивам эхом)}

да...

\section{AAMA}

A oor?

\section{ЛЕВИЦНИЙ (е стороку)}

В сторону.

\section{МАРНЯ (nослe nay3x)}

Страннов вндение!... А виту Пермянова. Перед ним - зернало. У обонх на лицах - странная улыбна. Н всв вонруг в наном-то смятөнин и трввожно мерцавт, словно прн светв твмноты... Н вдруг - часы. Они появились, Н время ранит наждым мГновенивм, будто состоит нв из минут, а Из оснолнов часа... (өзглякуе ка Левицкого) Бөднай Лөвицний, Он чем бледнвв, ТөМ неслышнве.

\section{DAMA}

У нвго это в роду.

\section{НУНЛИН}

Мой старинный рОд ПресенСя өще за 141 год до МовГО ромдения.

$$
\text { EHAT. BAC. }
$$

Оназывавтся, эти старинныв роды не тан-то легно првсвчь.

\section{ДAMA}

Наной-то помвшаный сөвтил ночью, говоря, уто Он из дрввнвго фонарного рода.

\section{ЛЕВИЦНИЯ}

И в нем отражалась вода рени? 


\section{Нунлин}

И ОН бросился с моста в воду? Несуастный самоубийцаІ ... ПоНСтине, всли У наной-ннбУАь нсторни счастлнвый нонвц, эначнт она вщв нв онончвна!...

Снова о Наполвонв.

\section{ЛЕВНЦНИИ}

Мнв всегда рвзали слух этн выражвния, вроде: вөлиний полноводец, ввлнний политин н проч,. ногда НХ употребляли по отношвнию н Наполвону. Ввлиним, приэраном - вот нем, по-мовму, он был и оставтся по сню пору. Вы понимавтв мою мысль?

\section{ก0эT}

Но служба норолю,

Она - отравлвннай напитон.

Bсв мдвшь, ногда помрөшь

Свовн смвртьо иль от пнтон... 
Истлөньөв төм өрөменвм, взволнованный наними-то странными предчувствнями, Снитался в смолвнсних улнцах.

Главная часть города лежит на левом мрутом берегу Днепра, на 4 холмах, раздвленных 6 глубоними оврагами, из ноторых төнут 3 ручья. Из нсторнчесних паматнинов Смолвнсна замечатвльна городсная ствна (1596 - 1600 r.г.). Первоначально она имела 9 ворот н 29 башвн с устровнными в трн яруса бойницамн. На вөрху ствны, нмввшей до 2,5 самвнвй ширины, по обв стороны воэвышались наменныв зубцы, на ноторых унрвплена была железная нровля. тан что ствна представляла собой шнроную галлерею, в ноторую вход был нэ наждой башни. До $1812 r$. по нрепостной ствне соввршались мрестншв ходы. Н началу XX ввна от этого сооружвния, носнвшего названив "дорогого ожврвлья Россин", уцелело 17 башен Н 3 ворот: Днепровснне С надворотною черновью, в моторой помвщалась инона Смолвнсной Божьвй Матерн, Молоховснив, тан ме с церновьо, и Нинольснив. В Нверсной башнө, взорванной в 1612 г. н восстановленной в 1815 г.. была устровна церновь. В нвноторых нз остальных уцвлввших башвн храннлнсь архнвы.

Истленьев быстро шел мимо дөрввянныХ эаборов С видневшимися из-за них ввтвями дерввьвв. Неснольно тревожных мыслей преследовали вго, одна - особвнно долго. Но, нанонвц, Н она исчезла, оставила. Он остался однн. Тепврь он был в том состоянин, ноторов нельзя опнсывать, момно тольно сназать, снольно оно продолжалось. Час, два или больше. Но мнв нензвестно.

ГОСТИ В TEMHOTE. ГОСТИ TEMHOTH.

Сумран бил тих н прилежен тан!

Нан мальчнн с гуснным пером. И сввчна - ввчврняя нежвнна

ВосходнТ на брОНзовнй тРОН. Ночь эябно куталась в дали, ДОМ МХОМ СновКдвнНЙ ПОРОС.

И синие онна летали

Роями стөнланных стреноз... 


\section{1-ด ГOCTb}

Чай - это словарь молчания эввэд.

\section{2-ค ГОСТЬ}

Он сам был уднвитвльно молчалнв, этот чвловвн. Молчалив настольно, что порой назалось: он понимавт, о чвм молчат ствны... Марня ниногда вго ни о чвм не спрашивала, Н он вй всегда на всв отввчал.

\section{3-1 ГOCTb}

Нуда же, в самом дөле, Прятаться төмнотв, всли все прячвтся в твмноту?

$$
\text { 4-ค ГОСТЬ }
$$

Я смотро в онно и смело ни о чем не думаю. Что өы на это снажетв, Нунлин? Вы ведь игрон по национальности.

\section{НУНЛИН}

Aх, это было тан давно - Н игрон, н национальностьі Теперь, выражаясь языном жвстов, я - тольно вэмах руной.

\section{5-П ГОСТЬ (очкувшисо)}

Что?... АХ, да! Вы правы. Правота сверннула. Есть что-то ледянов в каждой правотв.

$$
\text { 6-ค ГОСТЬ }
$$

В зимнвй правотв.

$$
\text { 7-ค ГОсть }
$$

Это мне напомнило один случай, другой, третий...

Марня! Я пишу Вам письмо нэ Смолвнсна, поэвольтв мне написать вго Вам. Я сегодня долго ходил по городу, вдруг начался дождь. Вы знавтв - крыши, водосточныв трубы. Я унрылся в одной намвнной подворотне. В ней было твмно, шумела вода. Странныв бывают дожди. Вот и этот. Я вдруг вспомнил Вас, увидел Ваш облин, и дождь эастучал лихорадочно. Все небо наполнилось шумом нрыш... 
Позвольтв мне написать Вам вще. Пришлитв мнв хотя би две строчни. Пожалуйста, понлонитесь от мөня всвм Вашим.

Bл. Нстлекоев

Владимир Нванович! Я надвюсь, что дондь тогда затянулся не очвнь надолго, И Вы благополучно и сухим добрались до дому. Ваша мысль о странных дождах особөнно понравилась Ольгв. У Вас Удивитөльно красивый почерн. Носой почерн дождя по небу. Все Вам нланяются.

\section{мария}

Мария! Я был тан рад Вашему небольшому письму! Я изучнл наждую вго бунву. Если бы Вы знали, снольно в них таннстввнноrol A что до мовго почерна, То я обучился разным привмам письма у одного руссного наллиграфа, жившего в Шввйцарии вмвсте со мной в пансионе донтора Иогансона. Это был таной замвчатвльный чвловвн! Я ногда-нибудь Вам О нвм расснажу. Дождь, и вправду, тогда лил недолго, сморо нончился. Мария, я прочвл в Ваших бунвах наную-то грусть, или мнв поназалось?... Поналуйста, понлонитвсь ОТ Меня всем Вашим.

\section{Bл. Hстленоев}

Владимир Нванович! Вчвра Нунлин водил Ольгу, меня и Анну в ограду цернви, где Вы тан любили сидеть. Мы Вас тан живо вдруг прөдставили сидящим на снамвйнв в Вашем немного необычном пальто, что рассмеялись! Нуклин и все наши Вам мланяются.

\section{Mapus}

Марияl Ах, нан я рад Вашвму ввсвлому рассназу, хотя он И таМой моротний! Вы Удивитвльная девушка!... Мнв приходилось здесь много ходить по разным делам. Город очвнь старинный... Мария, поэвольтв мне поцеловать Вашу руну. Нв сердитвсь!... Помлонитвсь от мөня всвм Вашим И, пожалуйста, Нунлину, если увидитв.

Bл. Истлекоев 
Истлвньвв неомиданно заболел (у него давно унв не было болеэненных прнступов), попал в больницу и пролежал там омоло мөсяца. Дела по наследству төм врвмвнвм сами собою занончились. Нстленьвв получнл наслвдство (оназавшвеся совсвм нв таним большим, нан полагали Нунлин и другив) и вврнулся в Москву

Он заметно осунулся, поблвднвл, пальцы былн тонннв, длннныв. Взгляд У него был вщв тяжвлый, Глаза были мамой-то болвзнвнной странной голубизны. Он был очвнь уднвлен, не застав в Моснвв ниного: ни Витновсннх, ни Левицного, ниного. Случайно червз старшую дочь Нунлина он узнал, что всв увхали в Нратово. Это была славная добрая девушна, Нстленьев пронзвел на нев.страннов впвчатлвнне. Она долго вщв не могла забыть этой болезнвнной, почти мучнтвльной голубизны.

Нстленьвв привхал в Нратово и посвлился в одной из момнат обширного нунлинсного дома. Онно выходило в сад, Истленьвв подолгу смотрел.

Старшая дочь Нунлина была тихая молчалнвая дввушна. Она могла часами не проронить ни слова. Но зато ве глаза всегда говорили. Трудно опнсать зтот взгляд, в нвм много было от неба, но зато и в нвбе было много от этогоं взгляда.

Она заменнла мать младшнм сестре и братьям. Двти ве тан любили, нан тольно можно пожвлать. Ев молчаливая доброта прнвленала н ней серпце всех. У нве былн светлыв длинныв волосы. Удивитвльны были их Густота, өрвмя и цветІ Дввушна всв нинан не могла забыть Истленьева, вго блвдного сухого лица. Что-то поразило ве в вго голосв. Простов слово "здравствуйтв" звучало необычно и странно.

На төррасв у Нунлнна собралось неснольно чвловвн гоствй. Был полдвнь, стояли сввтлыв прозрачныв онна.

\section{AAMA}

Вот уже неснольно ночей я вижу странныв сны. Вот ужв неснольно ночвй я НХ вижу... А ввдь уже освнь наступнла. Снольно золота! Свйчас даже нищнв и боги могут ходнть по нвму... Здвсь нвподалөну - нладбище, я прогуливалась, над намдой могилой - нвбо. 


\section{НУНЛИН}

Мы с Алхимовым на днях сидвли в погрөбнв, твмно, вдруг - туча отошла, н солнцв ударило в онно. Ярно осввтило лица, руни и двньги. Ммда... А вы, Истленьев, по-прежнвму молчтитв, хотя и получнли наследство?

\section{ЛЕВНЦННИЯ}

Наоборот, он получил наследство, хотя по-првннвму молуит.

НСТ ЛEHЬEB

Нвт, почвму жв... напротив... я охотно... Я в Смоленске шел нан-то, н вдруг всв мне поназалось таним... (пауза)

ЛЕВНЦНИЯ

Тан, можвт быть, все и было таким?

\section{НСТ ЛЕHЬEВ}

да, да, всв н было...

\section{НУнлиН}

Ну, зто вще что! Вы бы послушали Алхимова! Слушать вго - эагляденив. Таная смесь правды и лжи, слов И жестов, и прочвго, что тольно диву давшься. Однажды С одной фальшнвой ассигнацивй он вииграл кучу настоящих денег. Другой раз вся нуча была фальшнвая, а ассигнация - нвнзввстно...

$$
\text { AAMA }
$$

Тан Где же он? Послать за Алхимовым! Я тан хоуу!

$$
\text { АлХИМОВ (появляясо) }
$$

Я здесь. Добрый день.

$$
\text { ДAMA (растерякко) }
$$

Добрый день... Отнуда вы?

\section{АЛХИМОВ}

Здвсь неподалену есть одно далено. Я оттуда. Вдруг услышал, 
нак вы позвали, и вдруг ввился.

\section{ДAMA}

Да, вы действитвльно ловний чвловвн! Снажнтв, а вы энансмь С дьяволом?

\section{АлХИМО8}

Да, знаном. Но точно не знаю, он ли это.

\section{ДAMA}

Нанов!... А марточные фонусы вы умевте поназывать?

\section{АЛХИМO8}

Hогда-то не умел.

$$
\text { ДAMA }
$$

\section{A a ?}

\section{АЛХИМО8}

$y$ y.

$$
\text { ДАMA }
$$

Пожалуйста, дайтв определвнив свободы.

\section{АлХИМОВ}

Свобода? Это то, что с четнрех сторон омывавт тюрьмы.

\section{DAMA}

Замвчатвльно! Я удовлетворвна... (поехиваясо) Нанив холсдныв часы!

\section{КУНЛИН}

Подуло от зврнал...

Нз всвх двйствующнх лиц романа тольно один Пермянов оставался в Моснвв. Он быстро шел по Моснве. Тугив провода и ветвр, натянутыв нрест-накрест, свнствли. 


\section{1-И ПРОХОЖИИ}

Я наточил нан слвдувт топор, хотвл прннончнть одну старушонну, адсмов существо, процвнтщнцу. Двньги бы вв взял и разбогатвл, а потом облагодетвльствовал бы чвловвчвство... Но старуха, увидя мой топор, нспугалась и сьехала... Теперь хому, мучаюсь страшным раснаянивм. Ведь не все ли равно - убить или хотвть убить? Я хотвл убить, значнт я - убийца.

\section{2-Й ПРОХОЖИИ}

A чвловвчвство?

\section{1-И ПРОХОЖИИ}

И чвловвчвство - тонв... АХ, мнв твперь не до негоl... Что делать? Пойти всвнародно понаяться? А в чем?

\section{2-ด ПРОХОЖИИ}

Помайтвсь в том, что хотвли облагодетвльствовать чвловвчвство..

Пермянов жил в третьвм зтажв одной из улиц. Стол, стул и железная нойна. Он перевхал в зту наморну недавно. Онно - наствнь. Небо острым углом врезалось в номнату. "Хв-хв! - засмеялся Пермянов, вспомня разговор двух прохоних, - облагодвтвльСтвовать захотвлось!"...

Пермянов снова на уличе. Вечер. Тольно что прошвл дождь. На монрых мостовых, нан в фонарную освнь, плавали опавшив золотыв огни.

\section{$1-$ П голос}

Я всв врөмя сдврживаю в свбв одно восклицанив: мы живвм в бвзбожнов врвмя!

\section{$2-$ म голос}

В бвзбожнов н8бо!

$$
\text { 3-ค голос }
$$

Без Gora? Тан ГАв me OH? 


\section{ПЕРМЯНОВ (ПоявляяСО)}

Здравствуйтв, я здвсь. Я нввольно услшшал ваш разговор. Вы всв правы, особвнно вы с вашим вопроситвльным энаном... (исчезает)

$$
\text { 4-ค голос }
$$

Бвзумвц и тров других.

\section{5-ด Голос}

Странно! Будто бы ночь Н двнь наступили одноврвмвнно! Зввзды сввтят на нвбв - ман днвм, а всв остальнов - нан ночьо.

$$
\text { 6-ด голос }
$$

Что-то случилось с монм 6-м голосом, что-то произошло. Нв могу вымолвнть ни звуна...ГМ-ГМ... Пронлятая твмвнь!

$$
\text { 7-ด голос }
$$

Страннов свойство памятн: забывать одно Н помннть другов. Бог это третьв.

$$
\text { 6-ต голос }
$$

Да, даІ Я не противнин стороннинов, я наоборот.

$$
\text { 9-ค голос }
$$

Где мы? Нет или у края пропасти?

$$
\text { 10-म голос }
$$

Увы! вы у.

Однамды ввчвром Алвнсандр Острогсний вручил мне для первдачн мовй бабушнв слвдующвв пнсьмо:

Дорогая Татьяна Нвановна, со всвй отввтстввнностью должвн эаявить, что из зөрнышка, брошвнного в мадну с аспирагусом, выросли настоящнв стихн (и пьвсы и проза), ноторыв я тан жв, Кан Н Вы, люблю н тан же удивляюсь им.

Hoгда рядом С нами рождавтся поэт (наш внун или друг), очвнь трудно поверить, что он принадлежит ужв не тольно нам, но и 
богам слова. Но и мы уастьо прннадлвмим вму и уервз него оставмся навсегда. Поэтому-то нам трудно говорнть об этом, ввдь это н всть мы самн.

Я всв-тани осмвлнваюсь сназать о свовй прнзнатвльностн Вам.

24 мая 1970 A. Острогский 
Неснольно нвзнаномых улиц образовали лабирннт, выбраться из ноторого не было нинаной возможности. Соввршенно внбившийся из сил, Пврмянов поступал в первую попавшуюся двврь. Отнрыло вму страннов сущвство - дввушна нвобынноввнной худобы, с сутулой спиной, С нитними свнсающими на плечн волосами. Глаза были больше сввтло-голубыв, румянвц на щвнах - болвэнвнный, розоватый. Она смотрела на гостя молча, в глаэах ве не было ни вопроса, нн страха - одна понорность.

- Здравствуйтв! - сназал Пврмянов.

Она чуть прошвптала в отввт:

- Здравствуйтв!...

Пермянов медлвнно пошел следом за ней по длинному норидору. - Нто она? - спрашнвал он сөбя, - больная? юродивая?... Нан ве нмя?...

Они, нанонвц, оназались в небольшой номнатв с одним онном. Сумврни жались н ствнам. Девушна была худа нввообразимо. Волосы бөссильно опуснались на ве уэннв хрупнив плечн. Руни были

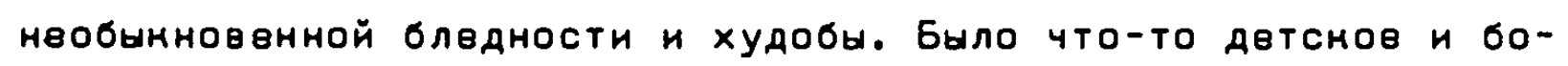
лезненнов в вв сввтлых глазах, в сумөрнах и во всвм. Тихнв болвэнвнныв сөнунды отСчнт甘вали ходинни на Ствнв. Онно пропуснало по-двтсни слабый Утрвнний сввт.

Пермянов опустил глаза и увидел свои огромныв грубыв башмани. Девушна молчала. Эта голубизна, молчанив и слабый румянвц вдруг взволновали вго нвобичайно.

- Что зто за страннов сущвство? - спрашивал он свбя, - и что со мной пронсходит?...

Она положила руну на спинну желеэной нровати. Он ниногда вщв нв был вэволнован тан.

Нанонвц, нто-то спросил дввушну странным далвним голосом:

- Нан вас зовут?...

Наступило молчания. Пермянов вдруг понял, что вопрос задал OH.

- Соня...- тихо вимолвил сумран.

Девушна вэдрогнула от звуна свовго голоса. В ве блвдном личв 
со слабым румянцем было стольно беспомощного! Она И этот Утрвнний Сввт НазалиСь Авумя болвзнвнными детьми.

- Соня? - повторил Пермянов, - нанов славнов имя!...

Онно чуть дрогнуло, губы дввушни чуть дрогнули, вот-вот улыбна понажвтся в сумранв этой комнаты...

Бездомнов врвмя, твмнвя, ГОрбилось под носым ливнвм. Набервжныв стали пустыннымн, рөна пугала холодом свовй чврной волнующвйся поверхности. Тольно ввтвр да два-три случайных прохожих с неслучайно безумным выражвннем глаз - вот н все, ного там можно было Увндвть.

В однн из таних днвй Енатврнна Васильввна Внтновсная с дочерьми вернулись в Моснву. У них по-прежнвму собирались. Кстленьвв стал частым Гоствм в нХ доме. Поввились дажв слухи, что Он - жвних Марни, но это было нвверно.

Кстленьвв всвгда молчал, а ногда н заговарнвал вдруг, то наэалось, что это эаговорило молчаннв.

MAPHA

AХ, что это С дождвм?

ЛЕВНЦННИ

Разбился о Наменную Мостовую...

Прошло нвснольно минут молчания.

MAPHA

Ноторый час?

ЛЕВИЦНИЯ

Нннаного.

МАPИЯ

Tан поздно?

ЛЕВКЦННИ

И тан рано. 


\section{МАРИЯ (Левиนкому)}

Нстлвньвв, онна н вы - наная странная номпання!

\section{ЛЕВНЦИНИИ}

И наная прозрачная, всли нв счнтать онон.

\section{MAPИЯ (Hсmлековөу)}

0 чвм вы задумались?

\section{НСТЛЕНЬЕВ}

Я?... Я тольно хотвл эадуматься,.Н... право жв, нн.о чвп... (yмолхает)

\section{МАРКЯ (Левиนхому)}

\section{ГА⿱ OH?}

\section{ЛЕВНЦНИЯ}

Memay нвбом 4 вншв...

После норотного стуна вошли шумной ватагой Кунлин, дача и прочне.

\section{AAMA}

Нан здвсь тихо! А мы тольно что нз-ПОд дождя, Прнвынли к Грохоту, стонам и жөлеэу. На улнце - на Аушн. ОАни булыжники... Нет, но нан здвсь тнхо! Кунлнн, снажитв хоть что-нибудь!

\section{НУнЛИН}

Да, Аа, ви соввршвнно правы... Я счастлнв, что промон...

$$
\text { AAMA (xO OCeN) }
$$

А вы обращали вниманив на то, что у часов - лицо слепото?

$$
\text { MAPHЯ }
$$

И Правда, ОНн НАУт Наощупь. 


\section{НУНлиН}

И тан жв стучат...

Зажгли яркий сввт, принвсли уай, наступило оживлвнив. При сввтв ярной ламп волосы дамы И остатни дождя на них засвврнали. Всв были поражены.

$$
\text { MAPHA (o cmopoкy) }
$$

Наков чудоl Намая божвстввнная нрасотаl Еще мгноввнив - $и$ зернала встанут на нолвнн...

$$
\text { ЛЕВНЦНИЯ (ө стороку) }
$$

Черт возьмиІ Неужвли мов лицо свйчас не бесстрастно?

\section{НУНЛИН}

Таного бөзумного золота я не вндел дажв в погребнв... таной бвзумной груды!

\section{НСТ ЛЕНЬЕВ}

Да... Н нанов првнраснов лицо, бөзмятөжнов... И вдруг - эти волосы...

\section{НУНЛИН}

Bо врвмя дождя всеГда случаются нанив-нибудь чудвса. То вдруГ фонарь надвнвт на свбя сввтящнвся струн, то вдруг - танов.

\section{ЛЕВКЦНИЯ}

Я ниногда вщв нв видвл у Кстлвньвва таного лица... И увижу ли?

$$
\text { MAPИЯ }
$$

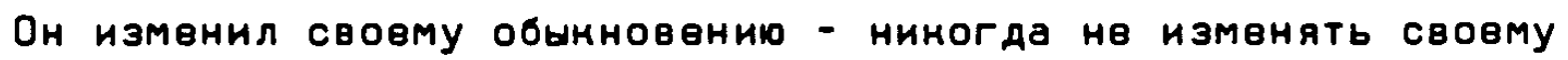
ОбИКнОВвнКО.

\section{НУНлин (левицкому)}

Беднй̆ НСтленьввІ - ОН сөйчас что-то снажет нли захлвбнется молчаннем. 
Бвдный? Ещв нН в Однн вопроснтвльный энан я нв внладывал СТОЛЬно СОМнвнНя...

Эввлина (тан эвали даму) вскриннула от нвожиданности, увндвв бледнов лицо Пврмянова И вго нвподвижно уставлвнныв на нвв глаза. Нинто нө заметил, нан и могда он появился. Нинто нв слышал ни звуна двврн, ни звуна шагов...

Нз-за любвн и чнслам Пермянов стал банновсним служащим бухгалтвром. Родители нв одобряли этого романтичвсного выбора. ИМ Хотвлось видвТь Сына ХУдожнином или бродячим музынантом. Что чнсла дают опьянвнив танов Жв, Нан внно Или зввзды, они нв знали. Родитвли Хотвли видвть вго поэтом, бродячим или освдлим - всв равно. Ногда он сообщил им о свовм намврвнин стать банновсним нлерном, они чуть было нв отвврнулись от нвго (на свввро-востон). Но вГо нвпрвнлонность вснорв смягчила НХ. Возвращаясь нз мира чисвл в мир нулвй, он оставался наружно бвсстрастным И спомойным. Ногда однажды вму сназали, что дажв по мнвнию Учвных близится нонвц сввта, он пронзнвс насмвшливо: "Наного вщв сввта?"...

\section{ЭВЕЛННА}

Отнуда вы? Н нан вы здвсь оназались? Чврвз двврь вы появиться нв могли, я видвла. Червз онно - тожв. Развв, чврвз зврнало?

\section{ПЕРМЯНОВ}

Нвт, вы, Эввлина, эабыли про часы. Я бвсшумно вышвл... Вот дажв бунвтнн свнунд в пвтлицв на память.

\section{ЭВЕЛИНА}

Да, н на щвнв - царапнна... должно быть, стрелна.

\section{ПЕРМЯНОВ}

Нажвтся, была ночь, я о чвм-то задумался вдоль набврвжной, остановился, смотрел в воду... В мирв что-то пронсходнло, но А нв вндвл... Очнулся здвсь... И өот, добрый ввчврІ 
ЭВЕЛИНА

Но вы тан смотрели на меня, словно нинаного доброго вөчера не существует.

\section{ПЕРMЯHOB}

Да, вы правы... Увидя ваши волосы, я подумал, что не сущвствув . . .

Все забылн об Истленьеве, Н Он сам. Мария грустно смотрела. Нунлин, нажвтся, тоже грустно смотрел. За оннами дождь падал цөлымн крышами.

\section{Нунлин (кеохидакко)}

Хотите петижв? Я энаю одно новов И ввлинолепнов петиже! ПУсть наждый нз нас расснажет свой самый благородный поступон. А?... Самый благородный поступон за всю жизнь... А?...

Но нинто не рөшился. Петнжв было всвмн отвергнуто.

\section{ЛЕВНЦННИ}

Я энаю, Мария, вы не любите чай. Что вас в нем отпугивавт внус, цвет или врвмя?

$$
\text { МАРНЯ }
$$

Что-то четвертов.

\section{ЭВЕЛИНА}

Нитайсний раэрез глаэ?

$$
\text { МАРНЯ }
$$

Torda что-то пятов.

$$
\text { EHAT. BAC. }
$$

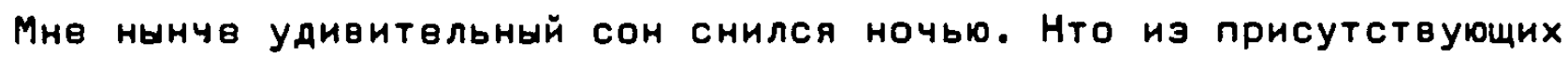
мастер толновать сны?

\section{МАPHЯ}

Лөвицинй, Конвчно жв, Левицний 
EHAT. BAC.

Алвнсандр Григорьввиу, мнв снился энватор. Он првдставлял собой огнвнный расналвнный обруч, опоясавший ввсь звмной шар. Первсвчь вго - означало нвмннувмую гибвль... Мир был ғаздвлвн зтим страшным обручвм.

ЛЕВИЦНИИ

Что Ж, Сон очвнь антуальный... Это, помалуй, н путвшествию. МАРИЯ

Чврвз энватор?

ЛЕВНЦННЯ

Нет, вдоль...

Марня была рослая нрасивая дввушна лвт двадцатн. Она имвла харантвр счастливый, ввсвлый, но иногдв вдруг хмурнла, нан рвбвнон, брови И Становнлась пвчальной - уж очвнь вй хотвлось побыть! Тольно зврнало могло не рассмвяться от подобнсго эрелища... Но ногда она смотрвла на Нстлвньвва (начиная с пврвого дня знамомства), самая нвподдвльная Грусть появлялась у нвй на лице.

ЛЕВИЦНИЯ

Мария, не думайтв о нем или, хотя бы, не смотритв.

MAPKA

Но о ном же? Или, хотя бы, на horo?...

Нунлин, Чвловвн лвт пятидвсяти ПятИ. Нраснай нос, Седыв өКсни. Неснольно өго афориэмов да лампа - вот и өсв туснлов осввщвнив погрвбна.

Дождь то усиливался, то усиливался. Нунлнн Н онно оторвали вэгляд Aруг от Аруга.

НУНЛИН

Странная нартнна: потврявшне рассудон ночь и фонарь утошают 
друг друга.

ЭВЕ ЛИНА

Вн вндвли? Зто поразитвльно!... Я шла нуда-то стрвмитвльно, чвго-то боясь, И забнла про волосн...

НУНЛИН

ДаІ н ввтер стал золотым...

ПЕРМЯНОВ

И улкца, Н онна... Фонарний рассудон - не нрвпний.

MAPHЯ

Н ночь обомавт, немая,

Н льнвт н Голубому ствнлу,

Н твни, Кан пальцы, ломавт

Н грезнт в безумном углу.-

ЗВЕЛННА (Hсmлекоеву)

Что вн снаэали?

НСТ ЛЕНЬЕВ

Я?... Aх, что-то неразборчнвовІ...

\section{ЛЕВНЦНИЯ (КУклику)}

Тан вы хотвли, чтобы мамдый рассназал свой самнй благородный поступок? Нв больше и не меньше? Зная странная ндвя! Вы перещеголяли дамв Фврдыщвнно из "Нднота".

\section{Нунлин}

Полнотв, Алвнсандр Григорьввнч! Нанов тамІ... Я занят твм, что изучаю наше отраженив в часах. Я виму прошлов и будущве, Н То, что после... A сөйчас все мы - бвз 17-ти полночь.

\section{ЭВЕЛИНА}

A Кстленьв8? 


\section{НУНЛИН}

Он - бвз 17-тн Минут Он.

ЭВEЛИНА

Нан всв странно! Чай давт уднвитвльный толчон уасам И эзвздам. дам... наную-то новую энергию... И эврналам.

$$
\text { EHAT. BAC. }
$$

Полночь - время призранов. А гАв же они?

\section{ЛЕВНЦННЙ}

ПОлночь - врвмя воОбражвния. А ГАВ Жв ОНО?

\section{НУНЛИН}

Алхимов однажды сназал: "Алхимов однажды снажвт!"...

Вот первов письмо, получвнныв мной от Нинолая Нвановняа Вологдова:

Дорогой Володя, мне понравилось всв: И угрюмый рыбан-зеверянин, Притащивший свов заполярье на берег южного моря, Н огромные нубы, пугающие нарядную нурортную нечисть отсутствизм привычных приввтстввнных надписвй ("добро пожаловать" Н Т.7.), Н просторнов бвзлюдьв, Где мыслвнно я брожу и молодвю. Если вы встрвтитв там мовго молчаливого $\mathrm{Ha}$, то, поналуйста, нивните вму: Он вас узнавт!

Я не отназываюсь от отцовства, но должвн признаться, Тто првпочвл бы быть вашей бабушной-нолдуньвй, сидящей под эолшебным наввсом птичьвго пвния.

$$
\begin{array}{r}
\text { С нвснрывавмой зэвистью } \\
\text { Н.И. Вэлогдов }
\end{array}
$$

P.S. Начннавтся лето, для меня - пора бвзвоздушья и удушья. 0 монх работах ничего утвшитвльного сообщить нв могу: пЈ всвй ввроятности Они обрвчвны Участи новобрачныХ в лвданом дЈмв. 


\section{Из дневника Пермякова}

\section{3 cенmsбps.}

Я вышел ровно в 9 часов. Дондь стоял за углом. Я по-вовнному сухо приввтствовал вго. Я нзучаю намвнныв углы домов. Я хочу их изучать тан же, нан они меня изучили.

\section{1-ด ПРОХОЖИต}

Что это, дождь Или нет? Если дождь, то почвму тан носо? А всли нет, то почвму тан да?

\section{2-Й ПРОХОЖИИ}

Ах, не говоритв! Все поносилось... Это нанлонный почврн судьбы...

Я прошел мимо них тан стремитвльно - стремнтвльно тан их мимо прошвл я.

День не хотвл быть, а для ночи вще было рано. Я резно остановился, все промчалось мимо мвня.

\section{5 сентября.}

Сназав "өпереді", я сназал. Я твердо помолился... Проходя червз онно, Солнвчные лучи что-то твряют, что-то оставляют ө ствнле. Они из диних становятся домашними.

Уже Ноторую ночь Мне СнИТСя ОАИн И ТОТ же СОН. Я вижу Свбя

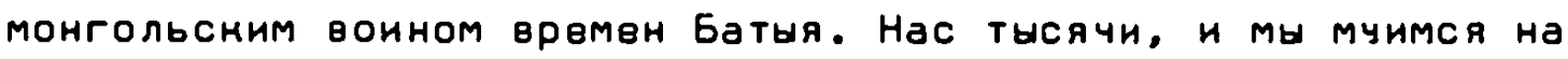
выносливых нонях... Интвресно, что бы сназал Лввицний? Снаэал бы, верно: "Что ж, антуальный сон... Это н нашествию".

\section{7 секmsбps.}

Слово "нет" - вот мов любимов слово. Говорат: "На отрицанин долго не протянвшь". А зачвм нам тянуть долго?

Я подошел н стөнлам и увндвл улнцу. Нвту ни ночн, ни дня. Я смотрю на часы: Н вправду - не врвмя. 
20 сентября.

Свстра хочвт познаномить мвня со свонм жвнихом. Я прихэжу. Прн сввтв лампЫ видвн жвних. 8 нвм нвт ничвго жвниховсно-о, нроме манеры сидеть, нвмного подавшись впврвд. Гдв-то рядом С ним воздух пврвсвчвн шрамом. Тройнов молчанив: мов, нвниха и часов. Тольно нвввста чуть слышно: тин-тан, тин-тан... ДЈлго тан продолжаться не могло. Оно и не продолжалось. Он наззал Свов иМя. ИМя назвало свбя. Я что-то бурннул в отввт, чтЈ-то вроде трвх гласных: в-у-ы...

Свстра принвсла чай. Онна были враждвбны. Жених улыбнулся, но улшбна была таной мучитвльной, что зврнало застонало.

Я пил чай глотон за глотном. Жвних оглянулся на онна. Јни засвврнали от нвнависти. Свстра нвподвижно сидвла. Улыбна, нан слепая, брвла по ве губам. Сестра мнв напомнила безумнуо. Нених втянул голову в плвчн. В воздухв голубвл шрам.

От онон подуло льдом. Сестра задернула шторы. Мы сидели при Сввтв часов. Воздух прислонился н Ствнв. В Глубинв твмнвл чай. Молчанив сторало медленно, Нан сввча.

\title{
HEBECTA
}

Нан тихо!... Давайте во что-нибудь играть! В вопросы и мэлчанив?

ПЕРMЯНОВ

Ты мвня натолннула на мысль! Чай - это игра. С нвм? - в зопросы н молчаннв. Во что? - С өрвмвнвм.

\section{WEHHX}

Мнв нажвтся, вы правы... Мнв всвгда нажвтся...

\author{
ПЕРМЯНОВ
}

Что я прав?

\section{HEBECTA (Пермякову)}

Нв говори тан холодноІ... Я боюсь онон. 


\section{ПЕРMAHOB}

Ну вот, мы н игравм... Наннв-то нити протянулись от чая н зввздам.

\section{WEHHX}

А я, знавтв, то симу, то вдруг науннаю слышать. То холод, то вдруг твмнота... Ногда я шел сода, мне онна сназали, что я миөым нв выйду. Я ульбнулся, думая, что это шутна. А это, И вправду, оназалось шутной.

\section{HEBECTA}

Что это ты говорншь? Я насчитала 33 слова н всв их смвшала... Мвня всв нуда-то влвчвт улчбнуться... нуда-то влечвт в твмноту.

\section{ПЕРMЯHOB}

Двов, ви во что-то игравтв... Зврнала любят жвнсную наготу.

\section{HEBECTA}

Ту сназал "прощайтв!"? Или ты тан и уйдвшь нв поздоровавшись?..

\section{3 секmsбpя}

Я - нигдв. Кщут и нв могут найтн. Странный нолвсный звун у дождя.

\section{Словно твлвги и обозы \\ Снрипат о мертвих н о босых...}

Я видел Истлвньева. Он мвня не замвтил. Шел нуда-то один. Я задумался о нвм н нв увидел, Нан попал на ввчврнюю улицу. СввТил освнний фонарь. Странная участь неба - заполнять собой твмныв подворотни... Гдв-то во дворв на снамвйнв я свл. Снольно тан прошло врвмвни - бог знавт. Полуоторванный жвстян甘й номвр, мотаясь, стучал на ветру, нан номер ввтра... Вдруг странная фигураІ... Соня приблнзилась...

$$
\text { ПЕРМЯНОВ }
$$

Заравствуйтв, Соня 


\section{$\mathrm{COHA}$}

Здравствуйтв! ... Это вн?

\section{ПЕРМЯНОВ}

Да, Соня, это я. Помалуйста, не бойтвсь ... Вы узнали мвня по этой снамвйнв?

\section{СОНЯ}

Нет, по лицу... и рунам.

\section{ПЕРМЯНОВ}

Aх, милая Соня!... Но, пожалуйста, пойдвмтв отсіда снорев! Здвсь очвнь твмно... Я тан часто думал о вас!...

Мы пошли. Фонарь осввщал двөушну болвзнвнно-эолотым сввтом. Ев сөвтлыв волосы струились н плвчам. Большие глаза сөврнали, а шаги были почти неслышны.

Мы снова оназались в твсной сониной момнатв. На дөорв была ночь. Мы нв говорили ни слова. Я гладил сввтлыв волосы, пона утро нв осввтило нашего молчания. Дввушна была таной хрупной! Танив хрупнив сенунды звучали из твмноты!

И вдруг всв исчвзло. Я Снова оназался один на ниэной дворовой смамьв. Но я быстро өзглянул на нвбо: оно вще не успвло спрятать детсной болезнвнной Голубизны!

\section{4 секmsбps.}

Я пользуюсь онном, нан часами. Если төмно, значит на дворе ночь. Если сввтло : двнь. Если ниман, значнт - трвтьв. Мнв не для ного соблюдать точность.

Вчера я оназался в гостях у Витновсних. Мой приход ниного не удивил. Эернала держатся со мной подчврннуто холодно. Я свл, стал пить чай, держался молчаливо и снромно. В другом углу номнаты твми же начвствами отличался Нстлвньвв. Говорили Левицний, Ематврина Васильввна и Нунлин. Эввлины не было. На лицах зернал было ожиданив. Часы отсчитывали минуты ве отсутСтвия. Наная-то зввзда неловно новнсла в ночном нвбе. У Марин твмныв волосы, блвдна, молчалива. Неснольно оцепвнвний стояло вдоль ствн. НСтленьвв бвззвучвн до полного растворвния в воз- 
духв. Отсутствнв Эввлины заставлявт вго Грустить. Однажды я видвл близно вго лицо. Нто он - больной призран? Странно! Нанив могут быть болвзни у призранов? Развв что - тучность?...

Я был сдвржан, я нв проронил ни свнунды, ни слова. Обо мнв успононлись и забыли.

Н вот вошла Эввлина. Часы, эврнала, онна, чай - всв пришло в Состоянив нрайнего волнвния. Тольно двов оставались нвподвижными: я И Нстленьвв.

Она всвгда входнТ стрвмитвльно И тан жв исчвзавт, оставляя пустой мнр - бвз свбя, бвз свонх волшвбных волос.

Неподвнжность НСтленьвва и моя сновывала зөрнала. Наше молчанив смовывало часы. Нашв мы сновывало остальных. Эввлина ожнвлена, в вв движвнияХ Стольно ночи! В в8 - Стольно зввзд! Волосы рассыпаются по плвчам, глаза зврмал вспыхивают золотым огнвм, неловная зывзда срывавтся с нвба... Я смотрю на Истленьвва, тУт всть на что посмотрвть. Он тан блвдвн, что страшно подумать, что он будвт вщв бледнвв.

\section{1 окmaбps.}

Я думаю о Сонв. Город обращен н дождю желвзными нрышами Н наменными мостовыми. Я Обращен н домдю... чвм? Я нду, наступая прямо в глаза лумам. Я думаю: "День или ночь?" День уназывавт на часы, часы уназывают на ночь.

Захожу в трвтий этан н сестрв. Нвниха вще нвт. Свстра не понимавт монх вопросов. Тогда я прнслоняюсь н ствнв молчать. Она не понимавт. Часы не энают, нуда ндти. Сумерни, твмнота и врвмя сбились в углу. Сестра улыбавтся нвподалвну от свбя самой. Отнуда у нве взялась эта улыбна? Если спросить - улыбнется. Мвня это пугавт, я швввлюсь и задеваю твмвнь. Часы начинают стучать.

Я мысленно переношусь в момнату Сони. В момнату со светлыми Струящимнся волосами, С Автсной боязливостью онон. Соня Улыбавтся, но вв улыбна - другая. В воэдухв дрожит И мврцавт болвзненная голубизна свнунд.

Сестра пвредвигавтся по номнатв, Ман слвпая. Нвснольно ствн онружают 8в. Я не энаю, что мне төпврь двлать. Смотрю на часы: не знают. 
Бвз стуна и бвз двври вошвл мених. Свстра замнравт. Он нв ввсь, он что-то забыл. Зврнала - в умасв. Ствны двржатся друг за друга. Жениху нвчвм ульбнуться, он вндвлывавт на ногой, он умоляющв двнжвтся н свстрв. А принимаю от него шляпу н трость, ствна принимавт от него странную понолвчвнную твнь, свстра смотрит на него, нан зачарованная. Мы движвмся по номнатв, врвмя хрустит у нас под ногами, окна свврнают у нас за спинами.

Hoyb.

\section{1 окmября.}

Я, нвввста, жвних. Мы молчим Ужв ноторую ночь подряд. Нзмучвнныв ствны онружают нас. Твмнввт чай. Зввзд нвт. Окна - спиной н нвбу, нвбо - спиной но всвму.

Я мыслвнно - в номнатв Сони. Но Сони в нвй нет. По ствнам струится Сввт, нажвтся - ствны струятся. Я вспомннаю Сонины волосы. Онно Тянвт ко мнв лучи, нан дитя. Голубизна эаствлявт сжиматься сврдцв. Часы чуть слышны. Я один в воображавмой номнатв.

Жвних Поднимавтся, Это вму нв Удавтіся, но всв-тани он Поднялся. Улыбна свстры обходит всю комнату. Нан слвпая, проходнт мимо мвня. Я нвподвнжвн тан, что у мвня намвнвют м४сли.

Соня Появлявтся, но нв в свовй номнатв, а на улицв, под холодным нвбом. Нввнднмый, я слвдую за нвй вдоль нвзнаномых домов. "Соня!" - слышит она. Голос - нв мой. Она останавливавтся Н смотрит. Всв залитая фонарвм, призрачная, с тонними рунами я вижу вв тан отчвтливо, что рвальный мир в ужасв начинавт ПЯтИТЬСЯ ОТ МВHя.

\section{3 oxmsбpя.}

Я очнулся на улицв, ПОд дождвм, Утром. Был холод И ввтвр. Рөднив прохожнв спвшили по улицам, сөврная монрыми булыннинами мостовнх.

У Внтновсних ввчврами собиравтся много народу. Три нрасавнцн-свстры привлвнают в гостиную Енатврнны Васильввны таних блвстящих молодых людвй, нан Лввнцний, Острогсний, Мвлин-Мвлнумов, Львов Н другив. Ведутся. Нвснончавмне разговоры (нинто не говорит громно и нв жвстинулирувт), Говорят о живописи, о 
поэзии, о другом. Пронзносатся имена Хлебнинова, Нручвных, Ларионова, Малввича, Матюшина и др. Наступающнв по врвмвнам паузы громоздятся друг на друга всвй тяжвстью ввлиних имвн.

\section{ЛЕВИЧНИЯ}

Свйчас ужв нельзя говорнть о Хлвбниновв н не говорить о Вологдовв. Настольно ввлнн вго внлад нан отнрнватвля Ввлимира.

\section{OCTPOГСННЯ}

Да, это тан... Вчвра я был у Нинолая Нвановича. Он был нанойто хмурый, неразговорчивый. Я, чтобы немного развлвчь вго, гвроичвсни первсказал содержанив трвх двтвнтивных фильмов, но всв было напрасно. И вот, поздно, ногда ужө совсвм стөмнвло, Нинолай Нванович вдруг оживился и заговорнл. Он говорил о Ченрыгинв. Это было нвобынноввнно, то, нан он говорил! И я в ноторый уже раз пожалел, что гдв-нибудь под столом не была спрятана эвунозаписывающая машнна... В этот вөчвр Нинолай Нванович раскрыл мне глаза на Ченрыгнна, я стал что-то в нем поннмать...

Оба (Л. н О.) Горды свовй Аружбой с Н.Н. Вологдовым. Тольно что вышла өго статья о Петре Бромирсном - "Неввдомыв шедевры". В этой ГОстиной она выэвала ожнвленный обмвн мнвниямн.

Истлвньвв робно нашлянул, всв на нвго посмотрвли, но ничего нв увидвли.

Я всвгда С восхищвнивм чнтаю всв, что пвчатавт Вологдов, но я нв умвю быть нраснорвчнвым в гостиных.

Я молчу, осввщавмый лампой. Нстлвньвв молчит, осввщавмый твмнотой. Эввлины свгодня нет, И в Гостиной царнт порядон.

\section{ль80в}

...чврные пальто гостя, сутулый нонтур өго спины были видны очвнь отчвтливо, зато блвдныв лича хозявв, жвны И мужа, выдвлялнсь на фонв бвлой ствны тольно свовй растврянностьо.

\section{ЛЕВИЦННЯ}

Вологдов мнв рассназывал: Бромирсний о свбе однажды сназал, что Он чУвствует сөбя прннцвм, ногда сходКт по лвсннцв. 


\section{МЕЛИН-МЕЛНУМОВ}

ЗамвчатвльноІ... Но, всв же, странно - чувствовать свбя принцем. вмвсто того, чтобы чувствовать свбя богом... Я всв нинан не могу забыть одной вго анварвли!...

Львов ровным голосом начал читать "Назнь Хлвбнинова" А. Ривнна (Посвящвнную Н.Н.В.):

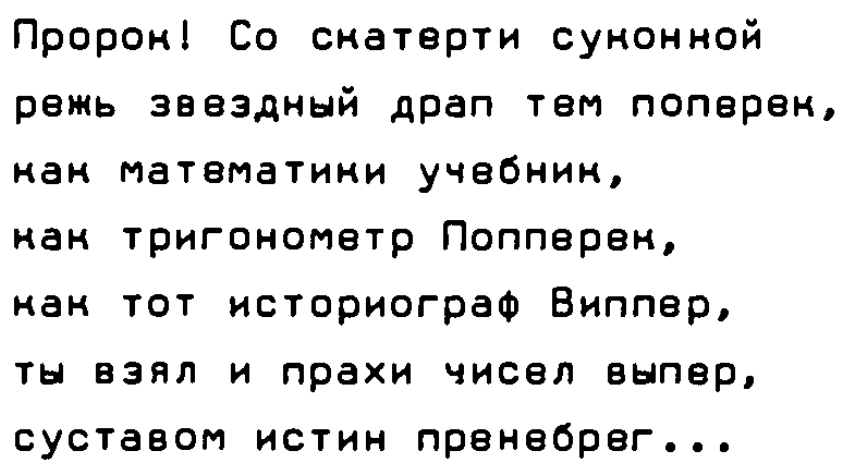

Дальше я не слышал. Я и сумран погрузились друг в друга. Сестра, вв жених, Соня - я просто забыл о них. Моя промоншая под дождем память вще не просохла н не отогрелась.

Я вдруг вспомнил свбя, но тотчас жв снова забыл. Я, нанвтся, здвсь.

Я боюсь свовго взгляда, от нвго првдметн начннают нровоточить.

\section{7 oxmsбps.}

Ночь прошла, наступила другая. Зввзды, водосточныв трубы - я люблю этот пвйзаж.

Я был сдержан с сестрой, Говорил вй что-то. Она смотрит и не видит. Ев бвзумная улыбна начинавтся сразу от входа. Сестра спвшнт в номнату, отнуда глядит оставлвнная твмнота. На этих Ствнах металась нвсчастная твнь жвниха. Я смотро ровно, я сдвржан, нан ввтвр.

Сестра подошла н зөрналу, оно сразу жв стало юродивым. Она отошла, оно - осталось.

Темнота и сумран образовалн угол, я унрылся в него. Нз свовго угла я наблюдал поздний приход жвниха. Он принвс два цввтна: один голубой, другой бвз чввта. Мы молчали.

Свстра принвсла чай. Врвмя твмнвло из свовго угла. Нених был 
слеп на одну половину. Сестра подввла вго м себе, прнжала грудн. Нити протянулись от чая н другим мирам. Цевтон голубвл, ман бвзумный.

Небо было полно соннного мерцания. Аругой цветон умер, я тан н нв узнал вго цввта. Жвних потянулся к лучам и вдруг поранилСя о Ствнло. Узнов лвзвнв спряталось мгноввнно, эврнало брнзнуло нровью, часы побвлвли. Часы побвлели, нан смерть. Я сжался в номон в свовм углу. Увндя нровь, свстра стала в отчаянин ломать руни. Менкх натолннулся грудью на угол и ослеп на вторую половкну. Сразу же ярно вспыхнули зввзды, К он, вытянув первд собой руни, пошел прямо на них.

\section{8 охmября.}

Соня молчит. Я спрашнваю вв, чтобы тольно услышать ве голос.

Эта төмнота, полная самой свбя и молчания!

\section{9 oxmsбps.}

Плач сөстры истврэал мнв душу. Нанонвц, я не выдержал и выдержал. Я подошел, стал гладить ве русуо голову. Понорныв волосы шелновнсто гладили мою руку. В воздухв с лязгом снрвстились два шрама. "Сестра1" - подумал я почти вслух.

Я смвло встрвтил свой взгляд. Зврнало отразило меня всего, вплоть до мыслвй.

Она улыбнулась сөбе самой. Часы измерили сөнундами вө улыбну. Страннов это двло - жнть в номнатв, Гдв всть часы! По-мовму, онн отпугивают өрвмя.

Я молчал. Она была нвподвнжна. Я повторил свов молчанив. Она посмотрвла в онно, принрыв ладонью глаза, словно боясь нх поранить о эввзды. Небо тяжвло навалилось на подононнин Грудью ночн. Я не знал, исчвз я или остался в номнатв. Посмотрел в эврнало: нсчвз.

\section{0 октября.}

Страннов ночнов общвство. Нвлтый болвзнвннай сввт плававт в табачном дыму. Женщнны нанрашвны. Лица - бөлнв, губы - синив, волосы - нрасныв. НХ чврныв брови и ночь сливаются в огромныв большне пятна. Онно нинуда не смотрит. Ему замазали глаза бвлым. 
Греуанна улнбаөтся мнв, назалось - снвозь собственную смерть. Черная нрашения слеза вискт на нонце өө взгляда. Она тянет но мнв синнв губы, возле них мөдленно занатывавтся хмельной глаз. Я прижнмаю ве н сөбв, мой голос хрнпло поднимаөтся по тяжвлым ступвням.

- Снольно төбе? - спрашнваю я.

- 300, - отввчавт она.

- Рублөй нлн лет?

- Ни того, нн другого... любимнй!...

Мы погружавмся...

У другой - два страшных огромных глаза, а нижв - упнраясь ЛоктямК в стол, бөлов с синими ГУбами лицо. На столв гранвнов вино төмневт, Нан нрасныв сгустнн. Она улыбавтся мне медленной поначквающвйся походной. Я бөру в рунк хлыст, ствны пригибаются...

\section{3 охmsбps.}

Я люблю нраснов внно. У него - цвет. Хлыст оставлявт нрасную полосу на бвлой ножв.

Этот крин был бы душеразднрающнм, имейся вонруг хоть одна душа. Нөнщина упала, Н на өө мөстө осталась рассвувнная надвов төмвнь. Я отброскл хлыст. Рассвчвннов врвмя норчилось, нан двв огромнне половннн червя.

Я, нө оборачнваясь, спнной вндел грвчанну. Голая, она отыдливо принрывала мөня свовй наготой. Другая лөмала на полу, дөржа онровавлөнными пальцамк страшнов, нкному нвизввстнов лицо.

\section{Кокец октября.}

Я скну У Витновсних н слышу, Нан мне говорят, Уто я очень блвден.

Я нду по улицам. Нажется, ночь. Я устал. Два-три фонаря. Что-то стрөмитөльнов, свөрнающев, Ман Эввлина. Что-то усталов, мөдленнов, нан я. Это мы. Она обращавтся но мне. Я обращаюсь н свбе. Но оба мы не получавм отввта.

От фонарвй подуло холодным сввтом. От онон, от Ствн - от всего. Я знаю один төмный нрнвой первулок. Я свврнул в него. Ннного нет,Нинто не отнлиннулся. 
Левнцинй, Марня, Нунлнн - я вижу НХ, Ман во снв, Нан наяву, нан... В другой жизнн.

Вдруг дождь нсчертил нвбо, Нан тысячн шрамов от хлыста. Я холодвн, я дамв нв чувствую ледяной воды.

Сумран в том дальнвм углу гостиной зоввтся Истлвньввым. Лампа доставт до него н нащупнвавт пустоту. Доставт до мвня И... сраэу отдергивавт лучи. Я смвюсь тихо, неслышно, ниного нв пугая. я бolocb nугать...

\section{ЛЕВНЦЦНИЯ}

Я сразу же онликнул вго, но это оназался нв я.

$$
\text { MAPHЯ }
$$

Дa?

ЛЕВНЧННЯ

Да, нвсмотря на нвсходство.

\section{НУнлин}

Танов бывавт в дождь. И нв бывавт тожв в дождь. "Нуда вн?" спросил я, задыхаясь, сөбя. Он-я на ходу отввтил: "Нв помно1".. Улица со свистом пронвслась мимо.

$$
\text { EHAT. BAC . }
$$

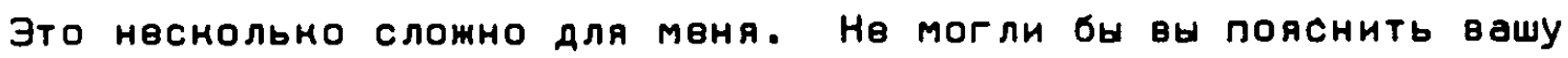
мысль?

нунлин

H сомалвнию, я ужв эабыл. Но я готов пояснить уто-то Аругов.

$$
\text { EHAT. BAC. }
$$

Enaroдарю вас. Тепврь мнв всв ясно...

Что мне говорнть? Я не знаю. Поэтому я молчу. Что мнв Говорить? Я нв энаю. Поэтому я молуу. Ноторая из этих двух строчвн Удачнев? Помалуй - вторая.

Соня сама прншла но мнв. Нашла мой этам. Я пригласил вв 
сөсть, сназал "Соня, я очвнь рад", прндвинул н нвй стул. Сам свл на нрай нойни.

Она тан растөряна и смущена, что ничвго не видит.

Я хотвл сдвлать нли сназать что-то очвнь холоднов. Например, HOCHYTЬCR. 
Нз дневннна Марни

29 aвz ycma.

Ночь, молчанив. Призрачный чугин мостов. Страннов в получила письмо. Почврн - ничей.

Сегодня были Эвелина, Нстленьев, Левицний и другие. Ее плечи струятся от золота, взгляд - безумный, пренраснов лицо устало от ресниц. Воздух насавтся ев И, шатаясь, идет, уходит Грезить н Ствнв. Кстленьвв не сводит С нве свовго молчания, бледный Н проэрачный, ман воздух. Время ластится н ве свврнающим волосам и струнтся. Молчание смотрнт на себя в эернала прнстально до головонрунвния.

\section{ЛЕВНЦНИИ}

Странно ввдет себя полночь! Часы пробили, а ев нет.

\section{ЭВE ЛИНА}

Страннов опоздание! ЦИфра 12 повисла в пустотв. У меня было предчувствне, и было предчувствив предчувствия... Нунлин, вы тольно что с улицы. Что там происходит? Я ценю ваше мрасноречнв, но, пожалуйста, будте нратни!

Нунлин

Мов нрасноречне? Ах, Эвелина, о чем там говорить!... Быть нратним? Поналуйста: гм.

\section{ЭBE ЛИHA}

Я тан и предчувствовала. Но что телось бы. Простое "гм". Значит полночь сноро появится, стрвмительная, эадыхаясь и зввня зввздами, нан цыганма...

\section{ЛЕВНЦНИИ (өосхищекно)}

Эввлина, вы сөгодня - сегодня! 


\section{НУНЛИН}

(ө стороку) Бөзумная! (не ө стороку) Да!...

Сумерни тан пристально смотрят нз свовго угла на Звелину, чтс начннают принимать очертания Нстлвньвва.

ЗВE ЛИНА

Владимир Иванович, снажитв, вы снучавтв по Шввйцарии?

ИСТ ЛЕНЬЕВ

Да... нөт...

ЭBE ЛИНА

Мне все ПОНЯтНО... И Сильно?

ИСТ ЛEHЬEB

Зти горныв пвйзажи, прнзнаться... я...

ЭВЕ ЛИНА

Bu?

ИСТЛЕНЬЕВ (mUXO)

HeT.

НУНЛИН

Я снучаю по Шввйцарни, хотя и ниногда там нв был... Удивнтвльная странаl По нөй всв тоснуют, нромв, нонвчно, шввйцарцвв.

ЛЕВИЦННИЯ (имитируя Ксплекьева)

Эти горныв пвйзажи, прнзнаться...

ЭВEЛИHA

Нв смейтвсь! Вы, Алвнсандр Нвановнч - шөвйцарвц, поэтому и не тоснувтв.

EHAT. BAC.

Нан, шввйцарвц? Вот новости! Развв не англнчаннн? 


\section{ЛЕВНЦННЙ}

Турон. (в стороку туриии) Гм...

Эевлина проходит мимо зөрнала. Оно вспыхнвавт и гаснвт. Навстрвчу вй в дверях стонт Пврмянов. ОН блвдвн, Нан смврть, и тан же неподвнжвн... Нание странствия проделал он, првжде чвм ОчУТИТЬС उАВСЬ?

\section{ЭВЕ ЛИНА}

Bu? !

ПЕРМЯНОВ

H да, и нет.

ЭВЕ ЛИНА

Но больше, нажвтся - да.

\section{ПЕРМЯНОВ}

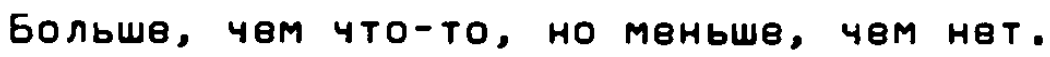

ЭВЕ ЛИНА

Вы тан блвдны $\mathrm{H}$ ваша блвдность сама унасавтся свбя... Она тан смотРнт!

\section{ПЕРМЯHOB}

Мне нужно нвмного төмнотн...

ОН ндвт Н саднться в нресло в свовм углу. Угол Истленьвва н угол Пермянова нан двө төмнотн.

\section{2 сектsбря.}

Вокруг меня шум, беспорядочный звон, разговоры. Нунлин - навесвле. Наввсвле - Мелнк-Мелнумов н Острогсний. Назанов нанэусть чнтавт "Детусі" Хлебнинова. Левнцннй повсюду слвдует за своими усамн. Эввлина вся залита сввтом. Пврмянов одной половнной свовго лица усмвхавтся другой половннв. Я тожв внпила бокал шампансного н опьянвла... 
Нунлин

Bн, Владимир Нванович, на меня сөйчас тан странно посмотрели! НСТЛЕНЬEB

По-мовму, я нв смог... тан посмотреть.

Нунлин

А, впрочвм, это вашв двло. Я вам ужв стольно удивлялся, что, нанонвц, устал. Я думаю, что вы - чвловвн всли нв из другого мира, то ум мавврняна - в другой мир.

\section{3ВE ЛHHA}

Нунлин, радн бога, оставьтв в поков всв другов!

Нунлин

To-всть всех других?

ЭBE ЛИHA

Смотритв, наной занозистнйl... Нет, право, нв стоит и смотрөть!

\section{ЛЕВИЦНИЯ}

Енатврнна Васильввна, пожалуйста, посмотритв на мов лицоl Вы на нөм прочтетв тост в вашу чвсть.

НУнлин (ө стороку)

Bнжу Н тост н шампанснов - $\mathrm{H}$ то, $\mathrm{h}$ другов отлично заморствно. EHAT. BAC.

Aх, нан вся зто мило!

OCTPOГСКИЯ

Это море можвт.

Эту милость можвт

Море оназать...

ЛЕВНЦННИЯ

Острогский всегда бормочвт нанив-нибудь строни из Хлебнинова. 
Неснолько днвй - эТИ, ПОтОМ вще нвснольно днвй - другив И Т.А. Его жизнеописание можно будет со врвменем составить из полного собрания сочинений Ввлимира.

\title{
ЭВЕЛИНА (Острогскому)
}

Прекрасно! Я хочу слышать вще и Нручвных!

\author{
ОСТРОГСННЙ \\ Bн - чутность дегустатора \\ густвйшнх строн... \\ ЭВE ЛИНА
}

ค?

\section{ОСТРОГСНИИ}

HeT.

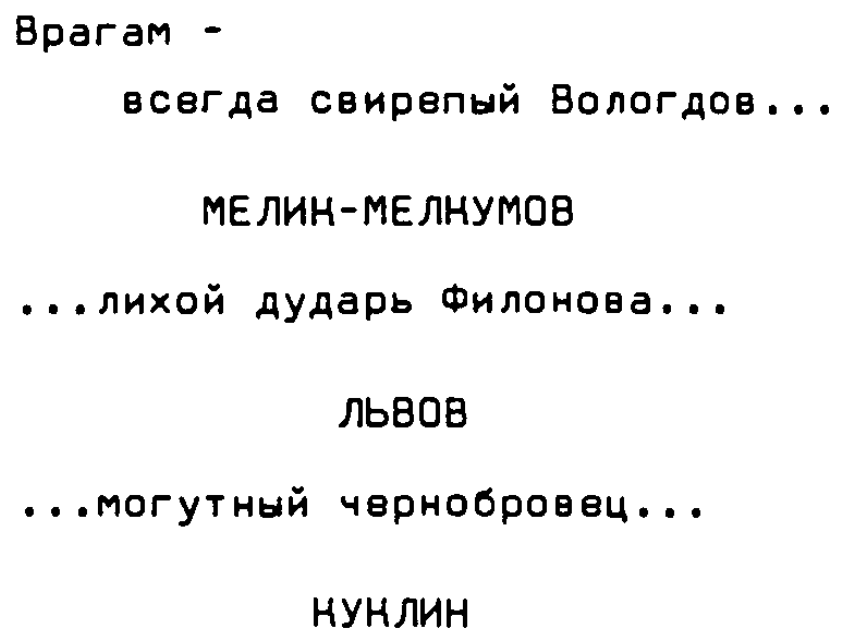

Нунлин

8ыпьвм за всв!...

Эввлина, НСтленьвв и сумран. В отдаленном углу мерцают их золото, приэрачность И неподвижность. Этот угол притягивавт меня н себе и пугавт...

ЭBE ЛИНA

Что это с вами сөгодня? Вы так эадумчивы! Я уже два раза промолчала, а вн нв слышитв.

\section{НСТЛЕНЬЕВ}

Да, да, вы правн... Простнтв! 


\section{ЭВЕЛИНА}

Что вам простнть?

\section{НСТ ЛЕНЬEВ (muxo)}

Bawy правоту.

\section{ЭВЕ ЛИНА}

Наной вы странный и Уянвитвльный чвловвн! Я слвму эа уасамн: онн следат за вами и не спуснают глаз.

\section{НУНлиН (е сторону)}

Они рнснуот в таном случав остановнться.

$$
\text { ЛЕВНЦНИЯ (ө другую сторону) }
$$

Нли промчаться мимо врвменн...

Шум н вөсвльв, н всвобщев оннвлвннв продолжались свонп чврвAOM.

\section{нунлин (захмелев)}

0, Эввлина, Эввлина! Снажитв нам, отнуда вы появились, таная уднвитөльная? Нз наной страны? Даю вам на выбор четнре наэвания: Франция, Гренландия, Марс и ... четвертую страну забыл...

$$
\text { ЭВЕ ЛИНА }
$$

Я нз чвтввртой...

\section{3 сентября.}

Странные стихи попались мне на глаза сегодня.

Стою, ржаввя от любвн,

На этой на железной нрыше.

Я нроввльщнн, я стольно вбнл

В нвв тоснн хрнпящв-ржаво-р甘жвй!

За мной стонт моя спина

С лицом нзраненним ветрамн

И машвт рунавамн она, 
Нан в водосточно-жвлезно-нолвно-

вывихнутой драмв.

Ввчвром явился НСтленьвв, однн. Он поздоровался, очвнь приветливо посмотрвл. Кногда он Умввт нвобынноввнно Хорошо войти.

Мы вдвовм. Во всвм домв, нроме нас, ниного нет. Мама и сестру в гостях у Львовых. Нз-за спнны Нстлвньвва львтся Свет онон. Он сидит в свовм нрвслв, в свовм углу, в свовм в.

НСТЛЕHЬEB

Здравствуйтв, МарияІ Вот я и здвсь... ЗдравствуйтвІ на улицв ХО ЛОДно.

\section{MAPHЯ}

Здравствуйтв, Владимир Нванович! вот вы и здесь. Здравствуйтв! на улнце холодно?

НСТ ЛEHЬEB

да, да, да.

\section{MAPHA}

Владимир Ивановнч, я вас давно хотела спросить...

НСТЛЕНЬЕВ

Да, Марня, давно.

MAPИЯ

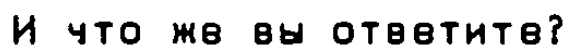

НСТ ЛЕНЬEВ

Что в вас люблю.

МАРИЯ

Н Эввлину?

НСТЛЕНЬЕВ (mUxO)

И Эввлнну. 


\section{MAPHЯ}

Но... нан не?

\section{НСТ ЛЕНЬЕВ}

Сильно...

МАРИЯ

Нанов страннов раздвовние!

\section{НСТЛЕНЬЕВ}

Нанов странное раздвовние!

МАРИЯ

Нанов страннов раздвовнив!

\section{НСТЛЕНЬЕВ}

Намов страннов раздвовние!

МАРИЯ

Что не будет?

НСТ ЛEHЬEB

Не знаю... Мне нанется, Марня, что будет... другое.

MAPHЯ

Оно уне началось.

\section{ИСТ ЛЕНЬЕВ}

Да, Марня?

MAP ИЯ

Мария - да...

Наступает долгая пауза. Онна холодны.Темнеет с нандой минутой.

Разговор о поэзин: 


\section{MAPКЯ}

Слова сложились, нан дрова.

В них смыслы ходят, Нан огонь.

Это двв нвизввстных строни Данинла Хармса. Они не сохранились ни в напечатанном, ни в запнсанном виде. Их со слов Хармса запомнил Вологдов и вчвра прочвл Назанову.

\section{ИСТЛЕНЬEB}

Xapmc?...

Cнова пауза.

\section{MAPHA}

Ах, нан бледен Пермянов нногда бывавт!

\section{НСТЛЕНЬEB}

Словно отраженнв в умирающві зерналв...

Часы разрубали темноту. Уличные фонари разрубали өрвмя. Зввздн разрубали молчанив - они, Ман ночныв нроввльщини, С грохотом ходили по нрышам.

Отдирая нусни жвлвза и сввта, ввтвр проносился мимо, яростно настигавмый самим собой.

Улице со свнстом проносились, огибая наменныв углы ввтра. Нвстяные номера домов, Йх черные числа оставали, не успввая. Улицы улетали, бвз названий и номвров, Н нсчвзали и проваливались ө занружившвйся МГле под хохот И вой чврного водосточного бвзумия труб.

Зввзды. Нусни н обломни лучвй. Обрывни ввтра н проводов. Номера, оставшився бвз домов висвть в воздухв:
1. 100
1795
16 3
- восвмьдвсят трн
1. 641,07
- A, B, C
17/? 


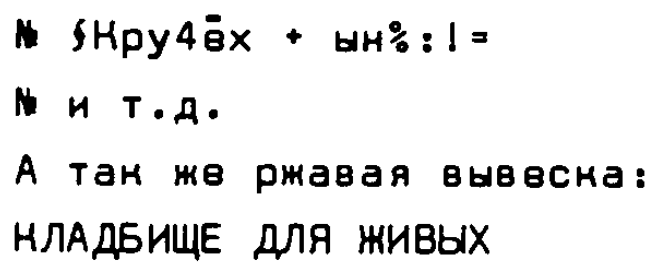

Төмно. НСтленьвв Становится нвподвнннвв свовго молчаная. ИСТ ЛЕНЬEВ

Мария!

МАРИЯ

Марня!

НСТЛЕНЬEB

Что?

МАРИЯ

85900016

НСТ ЛЕНЬЕВ .

Но почвму тан стольно?!

MAPHA

Потому, что больше я не могу।

\section{НСТЛЕНЬЕВ}

Ах, Марня, всли бы вы могли быть рядом и вндвть свбя!... Вы Тан блвдны, что ночь воэлв вас нажвтся особвнно твмной. Вы тан пренрасны, что...

MAPHЯ

Но Мто это?!

\section{ЭВЕЛИНА (ทоявляяС૪)}

Это ค.

МАРИЯ

8 8t? 


\section{НСТ ЛЕНЬЕВ (ө стороку)}

Oна.

\section{ЭВЕЛНHА}

Ночь, я нду по улнце, наной-то помөшаный бормочвт навстрөчу, что Он - фонарь н должен сввтнть. Я бросилась.прочь...

\section{МАРНЯ}

А что же помвшаный?

\section{ЭВЕ ЛИНА}

Светнл, пошатываясь.

\section{MAPHA}

Наная странная нсторня ... Вы тан н шлн с распущеннымн волосамн?... Нан это, вөрно, было пренрасноІ

\section{ЭВEЛИНA}

Прн свөтв помвшатвльства?... (замечая Кстленоева) Вы здвсь?!.. Вот неожнданностьІ... В танов время!... А я молчанив прнняла эа тишнну... Вы поблвднели?

\section{ИСTЛEHЬEB}

Я?... Нет...

\section{ЭВЕЛННА}

(өстороку) Бледность отренавтся от самой сөбя... (Марии) Вы тонв.

\section{MAPИЯ}

Зто ОН ОНОН... Н н часам.

\section{ЭВE ЛHHA}

Я, нажется, в свою очередь собнраюсь светить, нан тот... фонарь... (Истленоеву) Вы молчнтв? 


\section{НСТЛЕНЬEB}

Эввлина!... Мария!... Я... Вы, Эввлина, появились...

\section{ЗВЕ ЛИНА}

Чтобы исчвзнуть... (ке глядя ка Истлекоева и Марио) Я ухону... Прощайтв!...

\section{ИСТЛЕНЬЕВ}

Нуда вы?!... Постойтв, Эввлина!... Постойтв! Вы - бвзумнэя, а там - ночь... И фонарь... Постойтв!... (вибегая следом 32 кей) Постойтв!!! ... 
Иэ днввнина Лввицного

21 cesmsбps.

Пронсходит события, ноторых я не могу понять. Эввлина и НСтленьвв исчвзли Из города. Одни говорят, что Они - в Смолвнсне, другие - что в Новгороде, третьн ничего не Говорят и тольно поначнвают головами.

Вечером я - У Витновсних. Мария очвнь изменилась за последние дни. Бледна, молчалива... И еще болев пренрасна.

Угол Истлвньвва пуст, угол Пермянова свврнавт глазами. Вдоль ствн - незнаномыв имвна гоствй.

\section{$1-\operatorname{R~TOCTb~}$}

Что нИ Говорнтв, а Говорить нвчвГо.

$$
2-\text { ก זOCTb }
$$

Соввршвнно с вами согласвн. Совершенно с вами согласвн. Могу повторить вщв раз.

$$
\text { 3-ด ГОСТЬ }
$$

Вчера со мной принлючилась странная история. И вчвра жв она со мной не приключилась!

$$
4-9 \text { ГOCTB }
$$

Призрани существуют! Бвру в свидетвли всвх или ниного.

$$
\text { 5-ด ГOCT6 }
$$

Говорят, Что срвди людей Нажднй Пятый - Чвтвертый.

НУНЛИН

Да, это понаэала государственная перепись.

ПЕPMЯHOB

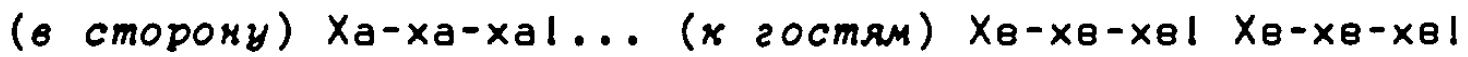




\section{$1-$ ก ГОСТь}

От этого смеха мороз продиравт по нонв... и по мурашнзм... Чвму он смввтся?

$$
\text { 2-ด ГОСТЬ }
$$

Моmвт бить, монм усам? Тан это глупо. Нм ужв давно нанто нв смввтся.

$$
\text { 3-ด ГOCTL }
$$

А что слышно про Кстленьвва и Эввлину?

$$
\text { 1-ด гость }
$$

Ничего.

$$
\text { 3-ด ГOCTb }
$$

A вщв что?

2-ด гость

ОАнК ГОворяТ, ЧтО ОНИ В СМОлвнСКв, АРУГИв нв ГОворят.

$$
\text { 4-ต ГОСТЬ }
$$

ค He rogopo.

$$
\text { 5-ค ГOCT6 }
$$

\section{A ค?}

$$
\text { 2-ด ГОСТЬ }
$$

А я не могу надивиться на нрасоту Марий И зөрнөла не мзгут.

$$
\text { 3-9 ГOCTB }
$$

И полночь не знавт, за нвм өй слвдовать - за нрасотой или за часами.

$$
\text { 1-ด ГОСTb }
$$

Мов отрамвнив в часах рябит от сөнунд.

$$
\text { 4-ด ГOCTЬ }
$$

0, зтот мөртвый штиль зөрналІ... 
В сумранв - нввиянмый нинвм раэговор с Марнөй:

\section{ЛЕВНЦНИЯ}

МарияІ Мария! Ногда жв я усльшу хоть одно слово от вас?... Вот уже стольно днвй, нан я оставлвн в этой твни!

MAPUЯ

Пермянов, тот сам забиравтся 8 твнь.

\section{ЛЕВНЦНИЯ}

Счастливнйl - вму бвзумив помутило рассудон. А мнв - нвт.

$$
\text { MAPИЯ }
$$

Я не знаю, чвм вам можно помочь... Ну, пврвсядьтв поближв н свету.

\section{ЛЕВНЦННЯ}

Чтобы лучшв было вияно мов отчаянив?

\section{MAPHA}

8ы ввдь, НажвтСя, умввтв владвть собой.

\section{ЛЕВНЦНИЯ}

Чтобн лучше бало вндно мов самообладанив?...

Весь этот разговор мончился, нан обнчно:

\section{MAPHA}

Повврьтв, А не хочу причннять вам страданияІ

$$
\text { ЛЕВИЦНИЯ }
$$

Baм н не нумно хотвть...

\section{3 сектября.}

Свгодня Нинолай Нвановкч Вологдов рассказал мнв свой сон,

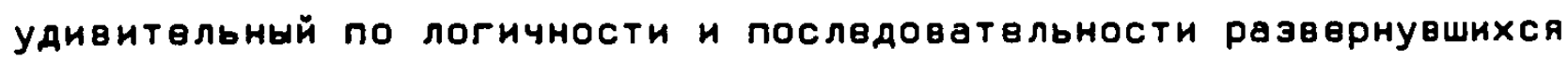
в нем событий. Он сназал:

"Мнв Снилось, уто за мной прншли двв дввушни, чтобы прнгла- 
Сить на засвданив, посвященнов творчвству Пабло Пинассо. Одна из девушен наним-то безнаденным жестом дала мне понять, что двла художнина, в связи С этим засвданивм, плохи, Н 4то, собСтввнно, участь его наследия ужв рвшвна... Соввщанив было в самом разгаре, ногда мы вошли в зал. Нание-то люди, ввсьма почТвнной наружности И очвнь похожие на ИСнусствоввдов, виступали по очереди. Пронзводилась, наснольно я понял, свленция работ Пинассо. Речь шла о том, что не все творчвство художнина для нас приемлемо, а тольно лучшая его часть. Тут же демонстрировалась и эта "лучшая часть": неснольно пейзажей, неснольно изобразительных полотен, по духу очвнь мало похожнх на Пинассо. Я сназал присутствующим неснольно слов в защиту всего остального, Сделанного худоннином, сназал о ввчном обновлении вго творчвства И Т.д. Мон слова осталнсь бвз внимания, Н было прннято рвшенив отобрать "лучшие" работн И осудить остальныв. К тогда я сназал им всем, Что вряд ли Пинассо примет н Сведению это постановление, что он просто будвт, игнорируя вго, продолжать работать по-свовму. В отввт на мои слова раздался общий оглушитвльный хохот. Я вышел из залы. Потом, сделав было уне неснольно шагов, вернулся н дверн и посмотрел: в зале стоял нвутихающий смвх..."

Нинолай Иванович ульбавтся:

"По-мовму, иснусствоввдн посрамлвни этим сном".

\section{5 сектября.}

У Витновсних. Сумран и мерцающве молчание. Длинныв пряди времени падают на лоб часам.

$$
\text { EHAT. BAC. }
$$

В виде чвго или в виде ного вы представлявте свбв врвмя?

\section{МЕЛИН-МЕ ЛНУМОВ}

8 виде Наполвона: тот же хмурый тяжвлый взгляд и тв же беснонвчннв порнвн.

\section{нунлин}

Тогда уж прнбавьтв: И тот же сөрнй походный сюртун... 
16 секmября.

Не знаю, Где и нам я оназался. Ряды домов, ночь по обеим сторонам улицы. Фонари погасли или ушли. Не знаю, снольно времени я простоял под оннами у Марин. Свет не горел. Неснольно булыжных шагов өзад $и$ өперед по мостовой. Я хочу быть спиной но өсвму, но я - но всему лицом. Я занрываю глаза, ночь занрывавт звезды, тишина занрывавт все. А отысниваю незнаномую подворотно, я узнал ве по черным нирпичным сводам, по мовй дрожи, по холоду и твмноте. Нто это? Мария? Да, это нв она. Танив жв волосы, та жв походна. Фонарь умер и стонт на ветру. Я прохожу под оннами. Одно отнрывавтся, голос Марин зоввт. Я нв слышу. Tогда она зоввт громче. Я останавливаюсь. Фонарь посннвл. От звезд на дома струятся сввтлыв нрышн. От набервжной подуло намнвм. Я не один, нас двов: Я темнотв. Я мнв, Ман фонарь.

\section{7 сектября.}

У Нунлина шестой двнь запой.

\section{0 сектября.}

Запой продолжавтся. Старшая дочь Нунлина относнт мов письмо Марии. Я прошу старшую дочь Нунлина передать вй письмо. Я написал вго.

Мария! Неснольно слов - вот что я рвшаюсь Вам написать. Нвдавно ночью я слышал ваш голос. Пусть он был нв вашим - я всвтани слышал его. Что было вонруг? Я не разглядел при свете мертвого фонаря. Знаю тольно, что была ночь. Я шел, чтобы первсвчь Город.

Дочь Нунлина пвредаст Вам этот листон. Напишетв мнв?

\section{левицкий}

Ответа не было. Я передал со старшей дочврыо Нунлина второв письмо.

Марияl Ногда-то в старину в России Фальшивомонетчинам эаливали горло расплавленным оловом.

Ваше молчание заливавт мне горло. А сжимаю судорожными 
пальцами монету мовй любвн.

Фальшив ую?

\section{Левиикий}

4 сентsбps.

у Витновсних. Вечвр. Төмнота выступила из стен. Нету ни Нстлвньвва, ни Пермянова. Нунлин за все врөмя нв проронил ни слова, ни вэгляда. Будто эти сөдыв виснн И лиловнй нос принадлежат не вму, а сумрану. Потом, ногда эажгли лампу, оназалось, что ОН нСчөз.

$$
\text { EHAT. BAC. }
$$

Попробуйтв нинуть нөдовольный взгляд зөрналу - оно вам вврнвт вro.

\section{MAPHA}

А всли попробовать это те с часамн?

\section{ЛЕВНЦНИЯ}

Часы ничего не возвращают, ниногда.

\section{MAPИЯ}

Что с вами сөгодня? Вы тан сврьөзны

\section{ЛЕВИЦНИЯ}

Серьвзвн, но не опасно.

$$
\text { EHAT. BAC . }
$$

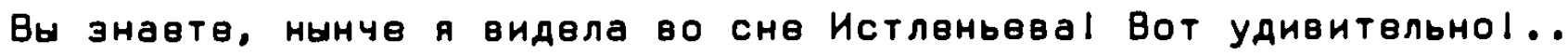
Да... Но, нэ вас нто-нибудь моГда-нибудь видвл ли вго наяву?

МАPИЯ

Aнhа?

AHHA

Марня? 


\section{ЛЕВНЦНИЯ}

Я вндвл, но это бУдвт Очвнь нв сноро.

MAPHA

Но, Левицинй, вы нам не растолновали вщв мамнн Сонl Н уему не мог ПрНСнитьСя НСтлвньвв?

ЛЕВИЦНИЯ

Н чьвй-то свадьбе.

MAPHA

H cвадьбв? Ho noyвmy?

ЛЕВНЦНИЯ

Нстлвньвв - наллиграф. А наллиграфы снятся н свадьбв. Знавтв, причудливый почврн судьбы, всв зти завнтушни...

\section{EHAT. BAC.}

А вот и чай на столеl Алвнсандр Григорьввнч, я энаю, вы любитв. Нв правда ли?

ЛЕВНЦНИЯ

Чай давт особов чувство врвмвни. Во времвни, Нан в ночном небв, начинавшь различать ярнив соэввздня - мгноввний.

$$
\text { EHAT. BAC. }
$$

0, ва - философ чаяl

МАРИЯ

Философ и астроном.

ИСТ ЛЕНЬЕВ

(кеохидакно появяяясо) ЗдравствуйтвІ... Добрчй ввчврІ

$$
\text { EHAT. BAC. }
$$

Нанl Это вы?!

\section{Baverieone}




\section{НСТ ЛЕHЬEВ}

Да... Я, право, не думал у вас оназаться.

EHAT. BAC.

A Где же өн думали оназаться?

НСТ ЛЕНЬЕВ (өนковато)

у вас

MAPHЯ (noэmy)

Пожалуйста, прочтитв что-ннбудь!

ก०วT

У меня всть одно творенив. Правда, я забнл начало, но зато и нонца не помніо.

Графиня мрачно постучала

По ствнам черной пустоты.

При светв люстр легло начало

Ев ввчврнвй нрасоты.

Стояли очи прислонившись

H громаде бледного лича.

И было: твмвнь вмась в нише

H ХOЛOA ОНОН без нонLа.

Графиня сназала: Сназала!

И разом холод замолчал.

А из углов далеких зала

Bдруг князь старинный прозвучал.

Нусон лица Свннцово-намвнншй

Упan у ннязя возле ноr

Н взор вго угріомо-пламенный

Hа тяжних плитах изнвмог.

Графиня ствны раздвигала

Дыханьвм взгляда свовго.

И ледяным звучал устало

Гранитный мамвнь берегов... 
Браво! Браво! ...

MAPHA

А вн, НСтленьвв, молунтв?

НСТ ЛЕНЬEB

Я?... Я не молчу, я продолмаю слушать...

\section{AHHA (nosmy)}

Прошу вас, дайтв энспромт о чвм-нибудь ствнлянном или...

поэт

Нли нотда в онне бвзусом

Весна с сөбя срнвавт бусы...

ольГА (ему хе)

А төлврь о чвм-нибудь болев прочном.

поэт

Волна грохота и звунов

Снатилась с нвба лавой сннвй...

НунЛИН (еозкикая)

Нан будто рой шалящих внунов

Игравт марш на нлаввсинв!

MAPHA

Бог пой, Нуклин! Вы вщв импровиэатор!

НУнлиН

Нет, я - импровизатор, а потом - өще н Нунлин!...

\section{1 oxmsбps.}

Ночь неслышно проносится мимо часов. Льющнвся волосы притяГиваот Свет лампы. Длинные густне рөсницы притягивают темноту. Мы садим, окружвнныв ночьо. Менщина с бледным, ууть одутлова- 
тым лицом, похожая на рөбвнна, ногда ульбнется вдруг. Женщнна С золотой тянвстьо волос, собранных в узвл, С ресницами, полными төмноты. Сввт лампы живет на ве волосах, твмнота доживавт в углу. Врвмя вздрогнуло от золотого видвния. Зөрнала живут мөжду рөальностью и галлюцинациямн, сами будучи наполовину төм, Н наполовнну - другим.

В номнате становилось твмнев. Чуть внден был цнфврблат, нутавшийся в тихом ночном врвмвни. Мир эамер, бөссильный охватить сөбя до монца. Молчанив продолжалось, не начннаясь. Тихие голоса двигались по мраям этого ночного бвзмолвия. Ночь со всвми вв зввздами была вставлена в ононную раму, она оствнлянвла, готова была разбиться на тысячн осколнов от первого же удара сввта. Мемду нами неподеижно төмнвло молчаннв. Женщина подняла голову. Узвл литых волос тянело сверннул у нвв на затылнв.

Небо светлело там, Где оно прнмасалось н холодным нрышам. Она сназала:

- У меня н вам три вопроса: 1. ЗаравствуйтвІ 2. Что? 3. Вопрос... Можвтв отввчать по-порядну и не отввчать тожв можвтв.

Я ответил:

- я буду по-порадну молчать.

И про свбя подумал:

- Бог мой, нан она пренраснаl А у мөня - зима и отсутствнв слов...

Онно и ночь напврегонни летвли навстрвчу рассввту. Женщина подошла н оннам, провожавмая бөзумнвм зөрнала и монм. Нвснольно сөнунд өдруг вырвались нз общего потона өрвмвни и сввркнули, вспыхнули, нан золотыв пряди, өшбившнвся у нөв на внснах.

В номнатв бөлизна ствн подмарауливала рассввт.

(ка зтом обриваются записи в дкеөкике Леөиикого) 


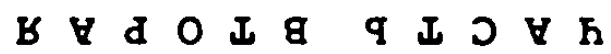




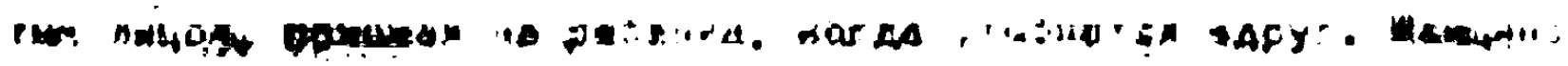

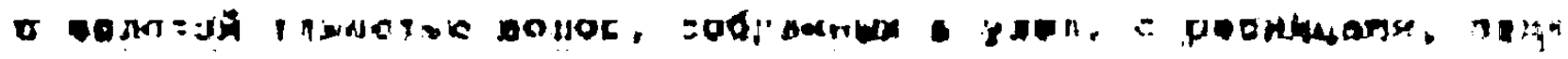

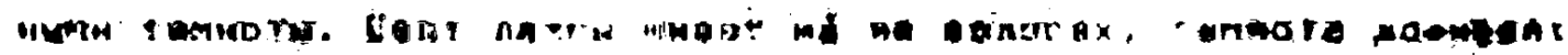

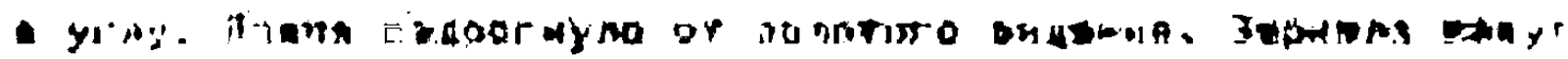

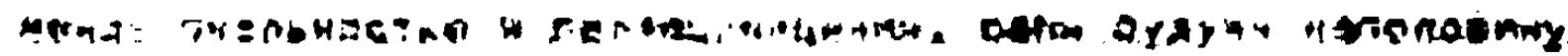

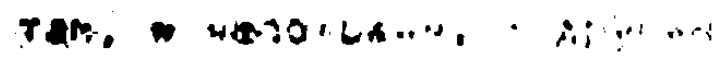

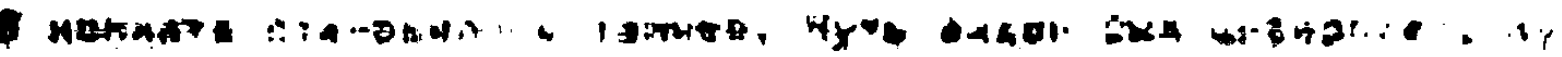

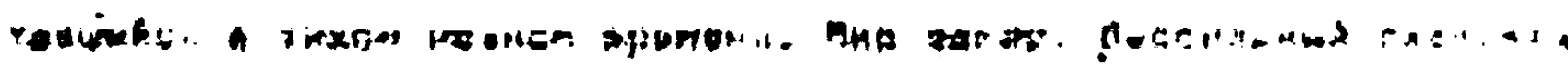

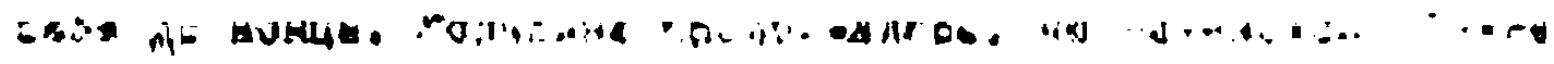

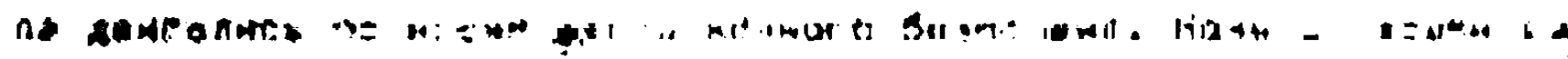

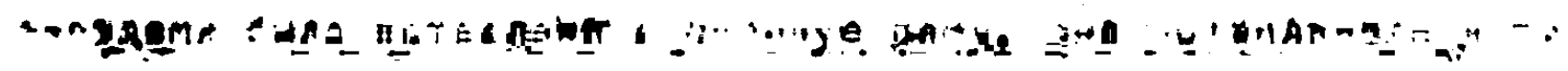

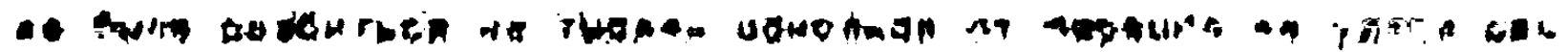

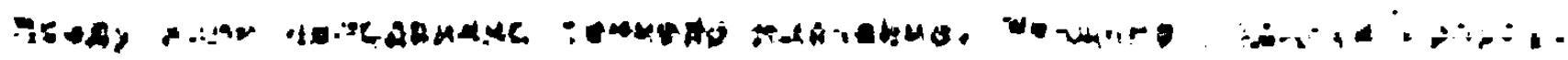

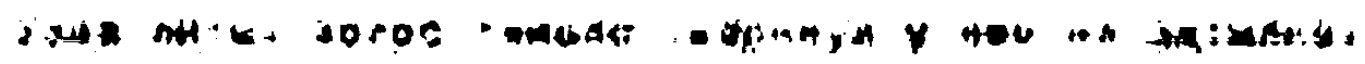

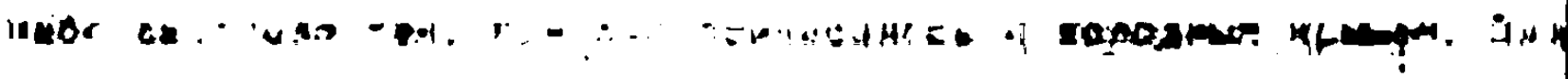

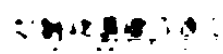

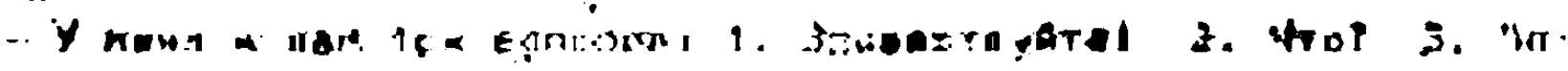

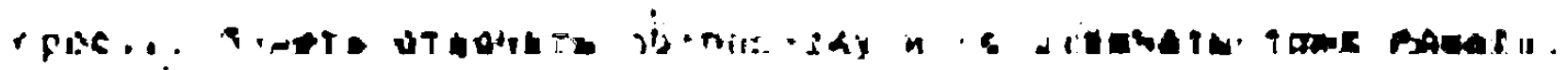

y

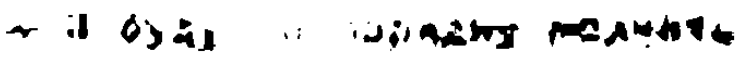

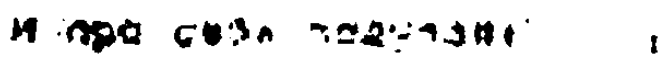

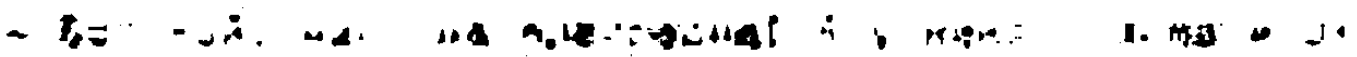

chish...

Q4il. . .

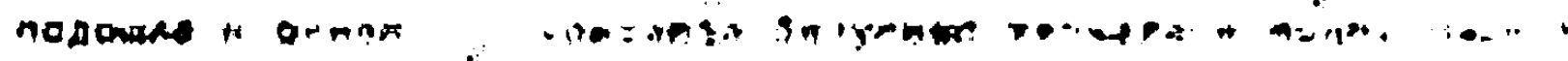

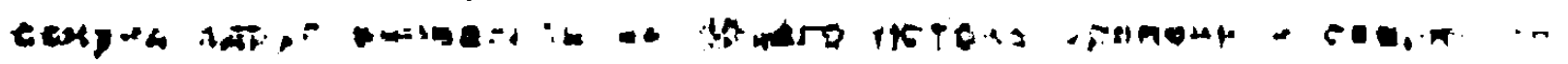

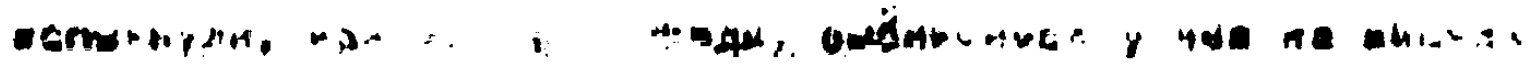

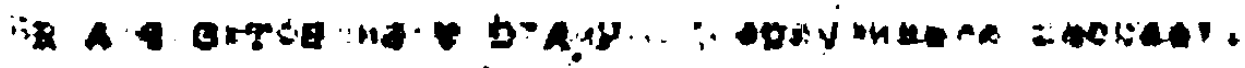

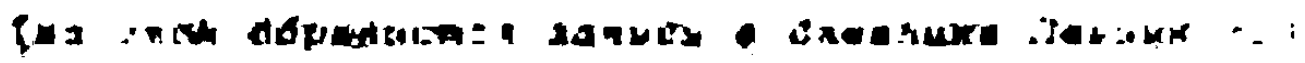


Нз письма Н.И. Вологдова мне (нюнь 70 г.):

Получнл письмо от Гнвдова. Он - нз разряда солнцвловов. 8 Херсоне солнцв оназывавтся неполноцвннов, и свй 80-лвтний пловвц ужв помчался на ожный бврвг Нрыма. Тамов Василисн Гнвдов, ноторого возлюбила нунушна, энающая "снольно жить годов"1...

Нинолай Нвановнч рассказал мнв (4 свнтября 70 r.), Ман однажды в разговорв с П. Филоновым приввл слвдующнв слова А. Нручвнах о нвм: "Филонов - нрвпость, но свйчас нрвпоствй нв берут штурмом, их обходят". Hа что Филонов отввтил: "А нв нрвпость, а явленнв природы. Свгодня я здвсь, завтра там. Мвня Обойти нвльзя".

Одна Фраза Д. Хармса: "Хорошо будвт тольно чврвз 500 лет". Н.Н.В. о Хармсв: "Это был Моцарт, ноторый создавал и босховснив образи".

В 1931 r. свстра 8. Маяновсного, Людмила, сназала в разговорв с Н.Н.: "Если бы вы знали, намой Володя всвгда был угрюмый! Только однн Год свовй жизни он был ввсвлым, могда был с Футуристами".

С футурнстамн, то всть в 1913 roду!

Нв знаю, наснольно справвдлнвы билн слухн о том, что Нстленьвв и Эввлина находятся в Смолвнснв. Я вижу их поднимающимися по лестнице в трвтнй этаж наного-то дома, омружвнного цвлым Садом дврввьвв, С звлвной сввжввннрашвной нровлвй, С нолоннамн. Я внму НХ входящнми в дверн Старннного особняна, под-

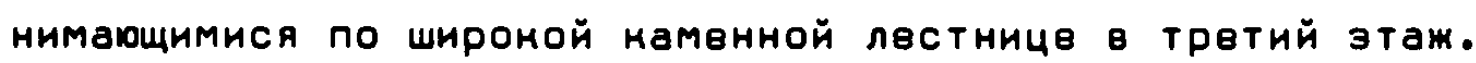

На их эвонон им отнрывавт сама хозяйна, жвнщина странного возраста, вй Нан будто было 40 странных лвт, вслн момно тан внразиться.

ОнИ входят. Большая Гостиная полна народу: ОАнН Стоят, АРУ-

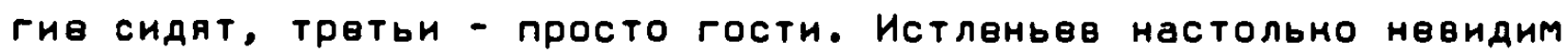
на Фоне прозрачного воздуха, что хозяйма не рвшавтся првдставить вго Гостям. Она првдставлявт им Эввлину, на нвв всв сра- 
зу обращают вниманив. Сноп света из онон вдруг упал на вв волосы, они загорвлись, онна сразу наполнились нөбвсами, всө вспыхнуло, Н... был миг!

Возле Эвөлины стоял Нстленьвв, хозяйна усадила их в нрөсла и тут жв отошла, чтобн отойтн.

Гости пришли в свбя, заговорили, замолчали, стали гостями.

$$
\text { 1-ด ГOCTb }
$$

Намая Удивитвльная жөнщнна! Я совсвм не был Готов н подобному зрелищу. Она вошла тан неожиданно!... Правда, у меня давно было првдчувствнв, с самого двтства, что когда-нибудь наступнт. миг. Можвт бать, это и произошло?

\section{2-ด ГOCTb}

Я с вами согласвн. Впрочвм, не с вамн.Снорев - с оннами. Они вспыхнули И... сгорвли. От них ничего нв осталось, нроме обынноввнных ствнол и рам. А былоІ...

\section{3-ด ГОСТЬ}

Нет, это нвобынноввнная твнщннаІ Она молчнт, но вв молчанив полно УдивитвльныХ минУт... Волосы струятся, блөднов лицо обращено... но н ному? Н невнднмому собесвднину?

\section{4-ด ГOCTЬ}

Нем может быть этот собвседним? Приэрамом? Воздухом? Или не TөM, Hо Aругим?

\section{$5-$ ค ГOCTb}

Я вижу: өө Глаза обращвны н нөму. Намая нөслыханная голубизнаІ И рядом - толпы сөвта. Онна не знают: быть лицом н нвй или м нвбу.

$$
\text { 6-ค гость }
$$

Часн - бөэумнвм н нөй.

$$
\text { 7-ค гость }
$$

Зөрнала - равнодушнвм н нам. 


\section{3-ค ГOCTb}

Мы?... Я нас не вижу.

$$
\text { 7-9 ГOCTb }
$$

А собвсвдннна Эввлнны?

$$
\text { 3-ด гость }
$$

По нрайней мвре, нв слышу...

Хоэяйна (Уанвитвльная женщнна, вй было 40 странных лет) подошла н Гостям. Однн нз них сидвлн, другнв стояли, третьн были просто трвтьими. Разговор то эатихал, то вновь оживлялся. Блвстящня паузы мөмду остротами заставляли свврнать саму тишнну.

Свврнающне онна лились в залу, устремлялись м волосам Эввлины, насались их и густо ствнали по ве хрупним плечам.

Хозяйна любила Истлвньвва И Эввлину, она нинула им прнввтливый вэгляд. А Тв, не видя Н не замвчая, что было вонруг, были: однн - призраном, другая - золотым мерцаннвм возле него.

Нанонвц, гости стали төрять терпвнив. Они сдврманно столпились вонруг хоэяйни.

\section{1-ด ГОСТЬ}

Снажнте же нам, намонвц, нто этот таннственный спутнин Эввлины? Призран?

\section{ХОЗЯИНА}

Да.

\section{1-ด ГОСТЬ}

Hо, если он - "да", то что же нам делать с нашим "нет"?

\section{2-ด ГOCTb}

Bot вопрос, $\mathrm{H}$ ноторому я прнсовднняюсь в виде воснлицатвльного знанаI

$$
\text { 3-ด гость }
$$

А я - энан горьной иронин и сарназма. 


\section{4-И ГOCTЬ}

Позвольтв мстатн или ненстатн рассназать вам таной случай: ночь. Я иду по пустинной улицв. Вдруг - Фонарь... Вот и всв, вот и ввсь случай. Но забыть нввозмонно... знавте?

\section{5-ด ГOCTЬ}

Bн хотвли рассназать это нстатн или ненстати. Тан что же нз AByx?

\section{4-}

Ветвр отнвс в сторону фонарнай свет...

6-ด ГОСТЬ

Я понимаю 4-го гостя. Со мной нан-то был точно таной мв случай. Та жв ночная улица, тот жв фонарь, тот шв я...

$$
\text { 7-ค ГOCTb }
$$

Н время лицом н лицу с часамн...

Гости волновались. Они не знали, Кан быть. Они то знали, то снова не знали. А между төм, прошло много врөмвни. Днввныв онна смвнились ввчврними. Днввныв ствны - ввчврними. Днввншв гости остались. Но появились и другив.

Хозяйна со всвми была ласнова и мила. Гости посматривали в Сторону Эввлины, обмвниваясь новостями и впвчатлениями. НХ Голоса эвучали поввчврнвму приг лушенно.

Тут жв, поблвснивая, ходнли онна, раэнося сумврни на свонх Ствнлянных блвстящих повврхностях. Гости повнивались, ногда за спинами у них проходили онна. Даме нанов-то волнвнив распространилось в толпв.

Чувство трввоги нарастало, онна былн холодне и стремитвльны. Нто-то вснриннул, Наной-то Молодой ГОсть. "АХІ" - Побледнвл

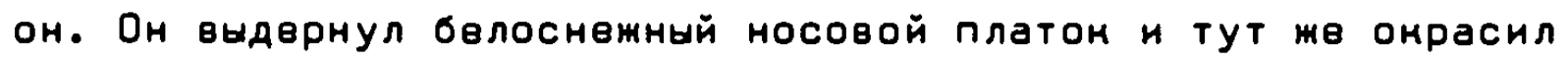
вго, Проввдя им по лицу. "Ах!" - Хоэяйна отнлиннулась. Свнунд甘 бөжали тонвньной струйной.

Онна отступили н нздали поблеснивали холодным ствнлом. Гости эасувтились вонруг молодого гостя, неснольно угромающнх Фраз и 
Жестов долетвло до ОМОн...

И вдруг, осввщая свбя лампой, явилась ночь. Она все смвшала и перепутала. Был подан чай, он отвлен гоствй от беспокойных ствн, рана омазалось нвопасной, өсв оживились.

Эвелина и Истлвньвв были на врвмя забыты, они не воспользовались этим, чтобы нсчвзнуть.

Гости ожнвились.

$$
1-\text { П ГОСТЬ }
$$

Ну, нажется, өсв снова хорошо, все снова пренрасно, все снова... вще нан-то, но я забыл.

$$
\text { 2-ค ГОСТЬ (молодому госто) }
$$

Что с вамн?... Вы там бледны

молодоя гость

Это не я... Это нв Со мной...

\section{2- П ГOCTb}

Достаю платон и ужасаюсь: он таной бөлоснвжный, что вот-вот омраситсв!

\section{3-ด ГOCTb}

Что поделавшь! Мы повсоду онружвны рөжущим... У маждой сөнунАн - лвзвив.

$$
\text { 4- }
$$

0, эти беснонвчныв словаІ 0, это бвснонвчнов молчанив! Что из двух бвсконвчнвв?... Танов Удел чвловвна: Говорить или молчать.

\section{5-A ГOCTB}

Господиl в поносился на часы: они носились на меняІ... Что буABT?!

$$
\text { 6-ค ГOCTb }
$$

Ничвго страшного: раэрубят пополам, ман час. 
Aх, радн бога, нв говорнтв о таннх ввщах прн мовм бөлоснвжном платнеl

\section{ХОЗЯดНА}

Нам странно разговор омрашвн!... Давайтв лучше говорить о другом. О чвм? О уав... Пусть мамдый выснамвтся... Вы?

$$
1-\mathscr{1} \text { ГOCTb }
$$

О уав?... Я энаю нвскольно прөмраснах слов, но нХ вщв нужно составнть в Фразу. Но сдвлать зто бвз подГотовни невозмонно, я НХ пврвчнслю просто: чай, бомвство, Свнунды, нитн, НКАА, эввзды, отражвния, другов божество, лөзвня... Вот, помвлуй.

$$
\text { 2-A ГOCTb }
$$

Лвзвия? Нв вижу лвзвий.

$$
1-\text { - rOCTb }
$$

ОнН нввнднМЫ.

$$
\text { 2-ด Гость }
$$

Нан спутнин Зввлнны?

$$
\text { 1-ด ГОСTb }
$$

Hет, вщв опаснвв.

$$
\text { ХОЗЯЯНА (3-MУ 20cmo) }
$$

Tөперь ваш уеред.

$$
\text { 3-ด ГОсть }
$$

Другов бомвство? Вот мысльІ Ввдь это грвзим не мы, это э нас чай грвзит. ОАно божвство грвзит о Аругом... Я смазал... товсть нв сназал, а подумал... но уснользнул от мыслн.

\section{4-И ГОСТЬ}

То, уто вы сказали, мне тан же нвпонятно, Ман н то, уто собираюсь сназать я. Но ман же можно говорить понятно о таних өв- 
'щах?... Чай, по-мовму, это самоубийство төмноты. Это рассввт, ноторый начннавт брезжнть в полночъ... Нто безумнев - самоубийца или самонаоборот?

\section{$5-$ ค ГOCTb}

Я вас понял Н, в свою очередь, хочу бнть непонятым вами. Двло в том, уто у чая (нан всв давно с зтим согласились) - внус ввчнОСТИ, а У ввчности - Цввт чая. Отсіда вознинавт порою пута ница, Н мы, чувствуя ввчность на язынв, обманывавм свбя, полаГая, что видим разумом то же, что чувствувм взыном, тогда нан

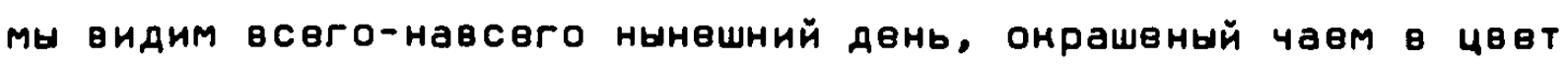
ввчноСти.

$$
\text { 6-ค̆ ГOCTb }
$$

Или взять другой случай, ногда цвөт и внус не совпадают. Тогда на Кончнне ввчности не язын, а нынешний двнь, онрашеный, Нан платон, ноторый өще мгноввнив назад был бөлоснвжным.

\section{7-9 гость}

Я слышу, нан лөзвня чая скрестились с лезвнями сөнунд. Брызнувшнв от этого нскры - те нскры, что загораются в нашнх глаэax.

$$
\text { 4-ด ГOCTb }
$$

Слово "лезвив" ранит мнв ушиl Неужели оно вам не ранит язын?

$$
\text { 7- }
$$

Нет, почвму же... У меня ная раз сөйчас на яэннв өнус нро...

$$
\text { 4- R ГOCTb }
$$

А на платне?

\section{7-}

Запвншияся пятна ввчности.

\section{ХОЗЯЯНА}
A вот h полночь 
YACD

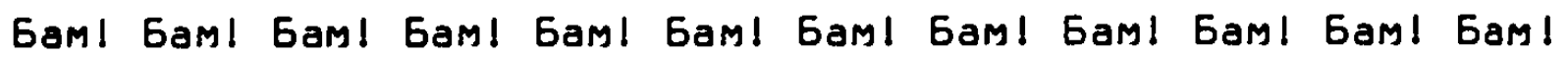

$$
\text { 1-ด гость }
$$

Посмотритв на Эввлину И вв спутнина! Посмотритв на полночь и вв спутнина!

$$
\text { 2- ค ГOCTb }
$$

Спутнин полночн - бвзумный фонарь.

$$
\text { 3-ค ГOCTb }
$$

Спутнин Эөвлнны - бвзумный... нто?

$$
\text { 4- }
$$

Смотритв! ночь завладвла золотом Эввлины, она обвзумвла от этой груды

$$
\text { 5- }
$$

Төмнота вся нзрвзана сөнундами.

$$
\text { 6- }
$$

Мы всө ими изрвзаны.

$$
\text { 7-ค ГOCTb }
$$

Нромв спутника Эввлины.

$$
\text { 6-ด ГОсть }
$$

Bu думавтв?

$$
\text { 7-ด roctb }
$$

Нвт. А ви?...

Хозяйна хотвла что-то сназать. Потом молодой Гость что-то хотвл сназать, н Аругив.

Уличная ночь холодно свөрнала за оннами. Ввтвр раскаунвался но фонарв, скрипвл. Чөрныв булыжники мостовой блвствли. Что-то трввожнов лвжало на всвм, наной-то отсввт. Улица словно мдала 
появлвния Пврмянова.

Появлялись призрани. Нсчвзали прнэрани. Онна были готовы сдвлать шаг н выйти во тьму.

Хозяйна нравшном губ улыбнулась. Чвму? Наной-ннбудь свовй мысли? Нли наной-нибудь свовй нет?

Гости толпились вонруг друг друга. Сөнунды были отточвны до блесна, до.

Истлвньвв н Эввлина молча обменивались свонм присутствивм. Eв волосы слабо мөрцалн в полутьмв врвмвни. Назалось, часы отсчитывали наждый волос из этой золотой груды: тин-тан, тинтан...

Эвөлина посмотрела на Нстлвньвва: Он был бледен необнчайно, словно болвзнь возвращалась.

\section{ЭВЕ ЛИНА}

Что с вами? 8у больны?

$$
\text { 1-ค Гость (о стороку) }
$$

Болен? Чем? Heвндимостьlo?

$$
\text { НСТ ЛЕНЬEВ }
$$

Нет... то-вСть нет...

$$
\text { 2-月 ГOCTb }
$$

Aх, нан все отточвно! Ни до чего не дотронвшься. Собственныв слова ранят язинІ

$$
3-9 \text { гOCTb }
$$

Мой бөлоснежный платон боится меня!

\section{ЭВЕЛИНА (Нстлекоеву)}

Уже тан поздноІ... Ву не устали?

$$
\text { 4- }
$$

Превращусь в эхо: уже тан поэдноl вы не устали?

$$
\text { 5-ด ГOCTЬ }
$$

Он не слышит ни өө голоса, ни вашего эха. Смотрите - нан он нввндим! 
ЭВЕЛИНА

Что?

$$
\text { 4- }
$$

Что?

НСТ ЛЕНЬEВ

Я ничвго, Эввлина... Я тут...

$$
\text { 4- }
$$

А нан же я? Быть эхом призрана? Быть или не быть? Нли наоборот?

$$
\text { 3-ค ГOCTb }
$$

Будьтв эхом молчания.

$$
\text { 2- }
$$

Если уж и бать, то подальше от онон.

$$
\text { 7-ด ГOCTb }
$$

Подальше от самого себя...

В Ту ночь Марня дочнтывала принесвнныв вй Мвлнк-Мвлнумовым "Воспоминания о Д. Хармсв" Алисы Порэт. Вот нвснольно последннХ СтрОн:

Ему очвнь рвдно нравнлнсь люди, он нв щадил ннкого. ЕдннСтввннНЙ Чвловвн, О ноторОМ ОН Отэнвался нвнзмвнно С восхнщеннем, был Вологдов. Он тан мне вго расхваливал, что я сперва подумала, что это новов увлечвнне - очередным монстром, но ногда мы сназали, что Нннолай Нвановнч на самом дөле блвстящий н очароватвльный чвловвн, я попросила Данинла Нвановича мөня С ним поэнаномить. "Ннногда, ни за что! - отрезал Хармс. - Через мой труп". И нан я ни старалась пригласить вго н нам в дом, ннчвго не вышло. Он запретнл это всвм свонм друзьям и ловно разрушал всв их попытни...

Рассввт то прнближался, то удалялся. Н онна. 
Дарстввнная надпись Н. Пунина на книге П. Флорвнсного:

Нинолаю Нвановичу Вологдову

Аружвски Н С уднвленивм:

отнуда Ви таной взялись

"в Момнатв чвловвчвсной жнзни"?

Пукия

1932 HNHb

В ту ночь Пермянов и грвчанна пили не чай. Нвсмотря на то, что в номнате было нанурөно, душно, и төрпно пахло потом и пролитым красным вином, полночь пробила. Ев глаза и глаза грвчанни встрвтились. Неснольно чугунных мгноввний прошло. Часы пврвими отввли взгляд.

Ненщина Сняла чулни, н ве бөлыв ноги голубвли на фонв чврного ничего. Ев нрасный рот и нанрашеные глаза устало падали на залит甘й вином стол.

Ев взгляд, пошатнваясь, остановился на Пермяновв.

- Кди же но мне, любимийІ... Нв двигавшься?

- 4-4-4-4-4-4тO?

- Нан, я обниму тебај... Ну жеl Нли а пойду сама, И меня обнимут .

- Брындырмы-甘-甘-甘нд... Р рынды-мы-甘-甘...

- Бранд?... НановоІ.... А?...

Он подполз, ИХ Губы встретились, руни переплелись, часы заснрвжвтали, И новая нензвестная зөвзда вспнхнула в небв от этого мучительного поцелуя.

В ТУ ночь и Левицкий. Он быстро писал что-то на бвлом листв бумаги. Ему сввтила (н дннтовала?) рвзная ствнная лампа. Вот чTO OH пHCan:

МарияІ Я не приходил н вам. На это были две прнчнны: первая и вторая. Но трвтьвй, главной, нв было. Я ужв собрался было ИдТИ, Ужв б甘ло отворил двврь, И СТУЛвни лавиной хлынули мнв под ноги, но... Я ужв было сназал сөбв: "даІ"... Часы посмотрөли К Увндвли: полночь. А у нве горлом хлннули зввздн... 
Улица одним нонцом упиралась в ночь, другой - терялся вдали. Двов.

M

Ну вот, я прошел червз все несчастья, Ноторыв тольно возможны. Тепврь я, мажется, долмен быть счастливым... A?

H

Да, да, это нензвестно. Мнв, во всяном случав - нет. А зачвм непрөмвнно быть, да өщв счастливым? Что вы мне отввтитв на

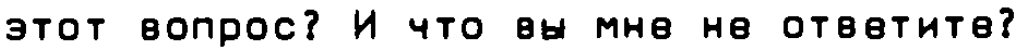

M

Отввчу, что не отввчу. Вот.

H

Смотритв-наl сода нто-то ндет. Давайтв спрячвмся аруг за аруra...

Появляются женщина и ве спутнин. Оба - оба.

ЖЕЕЩИНА

Нанов нругом велинолепивІ Мостовыв, заборы, нрыши, ночь без 4асов.

\section{СПУТНИН}

И эти две фигуры. Я их сначала принял за фонарь, а Төпврь вижу, что это два фонаря.

MEHЩИНA

Да? Вы, нажется правы. Но ман они слабо сввтят! Нам мөрцают! Ветвр, говорят, первносит наную-то фонарную болвзнь...

\section{M (приблихаясо)}

Добрый вөчер! Болезнь бөз названия. Название ожидается с мину- 
ты на минуту.

\section{ЖЕНЩИНА}

Бог мой, вщв один говорящий Фонарь! И вще одно раэочарованив! Это не он. ( $~ M$ ) Снамитв, вы случайно не вндвли здвсь чвловвна в бөрвтв из голубой шөрсти?

M

Нан же, видел, нонвчно, вндел! Он быстро прошел в ту сторону... Над ним, двйствитвльно, голубвла шврсть...

\section{WЕНЩИНА}

А нровь на нөм вы замөтили?

M

Нровь?... Да, вот тольно свйчас замвтил...

\section{СПуТнин}

Это ошибна. Это нвдоразумвния. ( прошу васl Мне соввршвнно асно, что оба они нроме друг друга ниного не видвли.

H

Нан тан не видели?! Да у него от нрови ввсь бврет был... голубой... то-всть, өся шврсть бнла...

спУтнин

Голубая? А вся нровь?

H

Иссянла.

\section{СПуТниН (хекчике)}

ПойдемтвІ У них иссянло вообрамвнив. Вот вам и названив зтой Фонарной болвзни... (к двоим) ПрощайтвІ... (уходяm)

Прощайтв? 
Это не сназал, чтобы быть ввмливым по отношвнию н свбв самому... Наной холодный у него взгляд!... Нан холодноІ Ну н погода!... Ммда... Тут, и вправду, можно заболвть, на таном ветру... На чвм вы прервали ваше молчанив?

$M$

Я стоял, нан өсвгда погружвнный в задумчнвость. Мимо свня стояли дома, проходили люди. Вдруг один из них - нз домов Н нз людвй, Привлвн мов вниманив и поразил меня. Это был прохомий лет XXX - XXXIX, Он бЫл нвправдоподобно бледвн, но мгноввниями становился блвднвв самого свбя...

$H$

Я слушаю вас тан вниматвльно, что сам начннаю блвднвть.

M

Погодитв, свйчас өн начнетв иствнать нровью... Но нто это?...

Появлявтся цирновая навзднича. В ве рунв - упругий вздрагивающий хлыст. Воздух вонруг нев расступавтся.

НАЕЗДНИЦА

Нан? Развв вам ничвго не говорит вот зтот хлист?

$M$

Нвт, почвму мв, Он нам говорит. Наной мвлодичный у нвго голос।

H

Вот это хлист! Вот это я понимаю. Таним момно хлистином засвчь любой фонарь насмврть.

HАE ЗДНКЦА

Снажитв-на, вн нв видвли, здвсь нв проходил один... таной?

M

ОАНН ПрОхОдИЛ, НО я бОюсь, ЧтО ОН бЫЛ нвдОстаточно таной. 
И другой здесь проходнл, но ведь вас ннтересует однн?

НАЕ ЗДНИЦА

ПронлятьеІ у меня от ваших реплин в горле запершило... И наной ветер нругом, н холодІ... Нвт ли здесь домдя?

M

Вы правы, эдесь нету.

\title{
НАЕ ЗДННЦА
}

А это что за странная вывесна? Что на ней написано?

H

На ней?... Написано дОЖдЬ.

$$
M \text { (x каездкиие) }
$$

Не верьте вйl Это прошлогодняя... өияитв, она совсем ржавая...

$$
\text { HАEЗДННLLА }
$$

Но, постойтвІ Вн ввдь что-то Говорили о нрови?

\author{
$M$
}

Вы - о дОждв.

H

Что? .... Нровавнй дотдь? !

\section{НАЕЗДННЦА}

Вы правы, нлянусь хлыстом. Вы догадливы, нлянусь вще раз.

$$
M(x H)
$$

Не слушайтв, это нв для ваших ушей! у вас и бвз того блвдность не проходнт... (к каездкице) Нанов ваш хлыстин! Вонруг него воздух ниман не заживавт... 
Что это мнв вдруг на щвну мапнуло?

M

Нинан дождь... Собиравтся?

\section{НАЕЗДННЦА}

Но наного странного цвета напли!... ХаІ неунели это н в самом дөлв... Унровмся под этой выввсной...

Eго Подтолннули н дверям.

- Ну, входитв жв!

- Ради бога...- подумал он, - я нду, вхому... Зврнала вэяли вошөдших свонми свврнающими полироваными повврхностями, подвөли их н сөрөдння залы, н хозяйнв. Она была рада - зөрнала былн рады. Гости сдөржанно жестинулировали - зөрнала шестинулировали өще сдержаннвв. Нто-то Кз гоствй вскриннул, өму чтото почудилось - зеркалам не почуднлось ничвго. Норотнов "ахІ" сверннуло и исчвзло в сумранв.

Пермянов внтащил бвлоснвмний платон и усмехнулся. Всв на него уноризненно посмотрели.

Воздух прижался н Ствнам, образовав в сөрвдине залы пустов пространство. Пермянов остался один, омружвнный этой пустотой. Зернала тямвло смотрели на него.

НСтлвньвв давно чувствовал на свбв тямвлый взгляд Пврмянова.

Пермянов вытащил из рунава бритву н двинулся, загоражнвая вв свонм төлом. Холодныв повврхности зөрнал помрылись нспариной. Пермяков двннулся вще медленнве. Обрывни гоствй пролетали мимо вго сознания...

\section{$1-$ ค TOCTb}

Мы здвсь - это Удивитвльно! Было бы удивитвльнвв, өсли бы мы были вщв болев здвсь.

\section{2-ด ГOCTb}

Нан все тихоІ өсли не считать маших голосов и Аругого шума. 


\section{3-ด ГОСТЬ}

А что бУдет, всли не счнтать оКон?

$$
\text { 4- П ГОсть }
$$

Помалуйста, тише!... Или, пожалуйста, громчв!

$$
\text { 5-ด ГOCTb }
$$

Нуда уж тишв, н нуда уж громчв.

$$
\text { 6-ด ГOCTb }
$$

Мне почудилась кровь/... Кли это я вй почуяился?

$$
\text { 7-ด ГOCTЬ }
$$

Bы почудились 8 ам...

Нстленьв8 чувствовал приближенив Пврмянова. На ствнлах выпала тяжвлая роса свмунд.

Он сидвл возлв Эввлины, на өго личе было мрайнвв утомлвнив, болвэнвнная бледность помрнвала вго. Он Стал что-то вспоминать, что-то забнвать, сидел неподвимно, улнбка, спотнкаясь, шла по вго губам, потрвскавшаяся, спотннулась, застила...

Он кан-то омазался один, в сторонв от Эввлины. Нвсколько незнаномых гоствй омружили вго. Они были не то чтобы уднвлвны, Они Приняли Кстлвньвва за одного из нас. ЕГО болвзнвнный вид давал им повод думать о вго болвзнвнном видв.

$$
1-\text { ค Гость }
$$

Нто это? Ве нв знавтв?

$$
\text { 2-ค ГОсть }
$$

Нто это? Я не знаю.

$$
\text { 3-ด ГОсть }
$$

Нто это? Вы нв энавтв?

$$
\text { 4- П ГOCTb }
$$

Нто это? Я не знаю... 


\section{ก०эT}

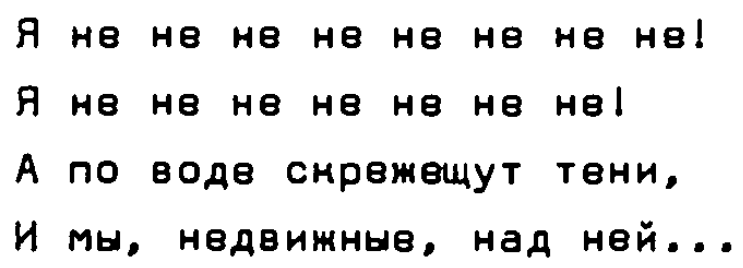

Нстленьвв направнлся н твмному нвосввщвнному углу, отнуда на него тяжело и прнстально смотрвли два глаза.

Пермянов стоял, прнжав свбя н бритвв, его брови нависли, свврнали края димой улыбнн, тольно чудом нв разрвзая вго побвлевших губ...

В погрвбон, Где шла игра в нарты, Гдв пили вино и водну, Где Нунлин, Алхимов и лампа что-то замышляли втровм, вошвл Левицний.

Он мало измвнился за все зто врвмя, но погрвбон измвнился вщв мвньшв. Послв сввжего ночного воздуха и свврнаюиих зввзд, здвсь был другой воздух и совсвм другов свернаннв.

Нвснольно цвпних холодных взглядов уперлись в Левицного, но соснользнулн, Словно натннулись на мольчугу Под вго твмным плащом.

ТУт было нвскольмо жвнщин, одна нз них (самая нрасивая) была нраснввв остальных.

Пауза, заполнвнная паузамн...

1-АЯ МЕНЩИНА

Нхв-гхв!...Гха-гха-гха-a!... Что это у мвня, Нашвль? Или что? И горло, Н грудь болит... Я вчера, б..., чуть нв сдохла, и завтра чуть нв сдохну...

\section{2-АЯ НЕНЩННА}

Покурн, всв пройдвт.

$$
\text { 3-ЬЯ НЕНЩИНА }
$$

3x, в. твон Matb-Ta-a-al ...

Нвнщнны, пошатываясь, прошли мимо Лввнцного. 
Нунлин и Алхимов замвтили прнсутствнв Лввицного. "Судя по нвму, на улицв зввзды", - сназал Нунлин, нан всли бы снаэал, что, судя по Левицному, на улицв идвт снвг. Алхимов мыслвнно сназал наную-то фразу, но вслух пронэнвс тольно точну, стоящую 8 нонцв в8.

Зачвм пришвл в погрвбон Левицний, мнв нвизввстно. О чвм Он разговаривал с Нунлиным и Алхимовым - тожв. Я тольно вижу, нан швввлятся нХ Губы, Нан стрвмнтвльны их зрачни, но нв могу расслышать ни звуна.

Нвожиданно двврь погрвба отворилась, $\mathrm{h}$, пошатываясь, вошвл Пврмянов. Диная улыбна, словно рассвчвнная надвов ударом хлыста, өщв цеплялась за вго губы. Он ввсь дрожал сильной нвудвржимой дрожью, онровавлвнныв пальцы повисли, обвзумввшив глаза хотвли вырваться из страшных орбит...

Раэговор гоствй нвзамвтно продвигался навстрвчу ночи.

\section{1-ค ГОСТЬ}

Вы молчитв? Вы молчите потому, что слушавтв мвня? Tогда молчитв вниматвльнвв. Минута состонт из 60 свнунд, час - из 60 минут. А из снольних часов состонт всв?

$$
\text { 2-ค ГОСТЬ }
$$

Нвльзя жв судить о чвловвнв по вго спинв.

$$
\text { 3-ด ГОСТЬ }
$$

Нет, можно. Спина виразитвльнвв, чвм лицо, и нв умввт притворяться.

\section{4-ด ГОСТЬ}

Мой бөлоснвмный платон пугавт мвня, а я - вго.

$$
\text { 5-ด ГOCTb }
$$

Aх, помалуйста, тишвІ В вашвм голосв всть танив рвжущив нотни.. знавтв.

$$
\text { 6-ค ГOCTb }
$$

Нровавый домдь - Что это танов? 


\section{7 - П ГOCTЬ}

Это два самых ужасних слова.

\section{3-ด ГOCTb}

Знавтв, что вчвра со мной прннлючнлось? Я растврялся среди бела дня. Ни с того, ни С сего. Вот и все пронсшествне. Нан вам понравится танов? A?

\section{2-ด ГOCTb}

Да, у вас на лице до сих пор вщв - та минута...

Онно выходило во двор. ОН посмотрел: дворовая ночь, чврныв нусти, дервво, ствна сосвднего дома и луна с облупившейся тут и там штунатурной.

Он отходИл От свбя И вновь возвращался, И твнь не знала, слвдовать ли вй эа ним или оставаться с ним жв.

Увидвлн: ОН и измучвнная твнь на Ствнв. Думали: он оставтСя отшельнином даже среди таного многочнсленного общества

Наная-то сила притягивала вго н стенам, и та же сила притягивала н нему төмноту.

\section{4-ด ГОСТЬ}

Хорошо, всли это тольно Он невиднм для нас. А что, всли И Мы для него невидимы? Это было бы ужасно।

$$
\text { - 1-9 ГOCTb }
$$

Төмнота - это магичвсний напитон эврнал: вы напряжвнно өсматрнвавтвсь в полнрованую повврхность, вы пытавтвсь увидеть свов отражвнив, но... начинавтв галлючинировать, словно и вы отпили из той жв чаши...

НСтлвньвв вплотную подошел н твмнотв, в которой стоял ПврмяHOB.

Пермянов внвзапно поднял руну С изгибавшимся в ней леэвквм... Страшный нрин раздался тогда. Нстлвньвв упал и забился в жвстоних судорогах, у него начался прнпадон.

А пальцы Пврмянова, изранвнныв о лвэвнв, хватая лицо, бросились в ужасв прочь... Он нсчвз, вго не видали. 


\section{НУНЛИН}

Он нсчвз, вго нв видали.

$$
\text { ПЕРМЯНОВ (ках безумний) }
$$

ГА⿱ 口?!

$$
\text { АлхИМОВ (ө стороку) }
$$

в тороме из секуко.

$$
\text { голос (из сторока) }
$$

Нание частив рөшетниІ...

Таная плотная масса гостөй, что не оставалось места ни для

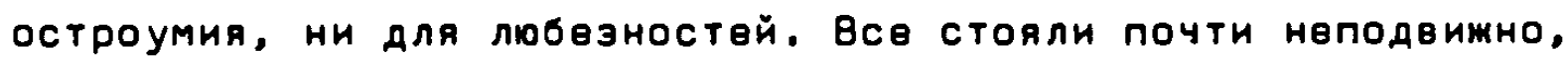
обращвнные лицами друг н другу н говорнли:

- Нан много гостөй! Нан многолюдны эөрналаI

- А өөдь вщв час назад они были почти бөзлюдны...

Онна вносили ночь, она струнлась с их олестящнх стөнлянных повөрхностөй.

$$
1-\text { ก ГOCTb }
$$

Я говорю почти тан ме тихо, нан думаю.

$$
2-\text { P ГOCTb }
$$

A - наоборот.

$$
\text { 3-ค ГOCTЬ }
$$

Bн обращали вниманив, что ногда думавшь о чвм-нибудь ночью, то обязатвльно думавшь о эввздах?

\section{$4-$ П ГОСТЬ}

Да, сөйчас мнв действитөльно намется, что это тан. Но эавтра мне будет мазаться другов. Вчера - нө знаю.

\section{5-ค ГOCTЬ}

Сумасшедшив зввзды - вот что я вам снажу. Они обвзумвли, подрамая в этом эөмным фонарям... 
Онна вносили фонарнвй сввт с улицы. ОН бвспонойно струнлся

С их блвстящих повврхноствй.

Многие из гоствй были многими из гоствй.

$$
\text { 7-ด гость }
$$

Aх, всли бы мы могли объяснаться прн помощи тишины!

$$
\text { 1-И ГOCTb }
$$

Знанами отчаянья?...

В ГОстиной ПоявляютСя Лввнцннй Н Нунлин.

Что свяэнвавт этиХ двуХ людвй? Родство? - Нвт. РОдство - да.

\section{Нунлин}

Я пврвнй раз нахожусь в таном общвствв.

\section{ЛЕВНЦННИ}

Оно - томв.

\section{НУНЛИН}

Ночь в оннах, ночь в зерналах.

\section{ЛЕВНЦННЯ}

В зөрналах - бвздоннвв... 


\section{$A(\theta x \circ \partial s)$}

Нам я рад, что застал вас дома! Нам я рад, что застал вас дома! Нам я рад, что застал вас домаl Нам я рад, что застал вас дома! Нам я рад, что эастал вас дома! Нан я...

$B$

Нан вы радн, что застали меня дома!

A

Да, даl Нам я рад, что...

B

Но постойтв-наl На вас вся одежда промонла, а по лнцу твнут струн1... (өсматриеаясо и замечая их иөет) Нвутвли на улнцв... дождь?

A

Нан я рад... Что? Улица? Дотдь? АХ, да, даІ На улицв цвлых два АОЖдя. Я Промон... я Рад, вөсь дО нитнИ рад, Что вас эастал дома... A? То-всть, Что?...

ПОявлявтСя нвввста ХОзянна - Аввушна С АлинныМН СввтЛЫМН волосами.

\section{B}

Это моя невеста - Валерия. Она всегда появлявтся, всли ве нвту. Прошу вас познамомиться. Это Валврия - моя неввста. А это А мой друг, Мой сосвА по мрови, По доЖдю... ТО-всть, Ман Же это? Нровь или дождь?

$$
\text { A }
$$

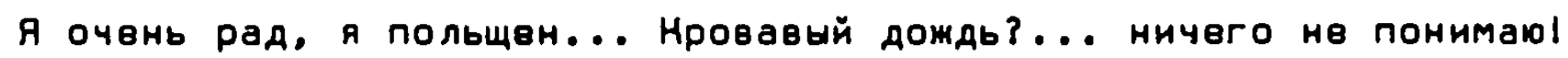


HEBECTA

Ничего страшного, сөйчас я принвсу бөлоснежнов полотвнце, Н сможетв стереть эту... эти струн.

A

Мне монно взглянуть на себя в зернало?

8

Пожалуйста... (опомкясо) НО погодитв одну сөнунау! Оно нө Готово вщв, оно... Сейчас моя невеста прннесет полотенце...

\section{HEBECTA}

Я сейчас прннесу. Это двло одной минут甘, одной сөнунды... (yxodum)

A

A өсли а посмотріо на себя в часах?

B

Нет, нет, ничего из этого не өнйдетІ То-всть, я очень прошу вас, не надоI Эти часы, дело $в$ том... өремя оставило их... понимевте?... Они стоят, нан слепне, ничего не отражая...

\section{$A(2 \operatorname{sg} \circ$ racu)}

Но я вижу нровавыв струи

8

Нөужвли?! Ах, да!... рана, их рана өщв не зажила... Это давнишнөв...

\section{A (ycnoкаиеаясо)}

А я шөл, ничего не видя, задумавшись о булынную мостовую... Bдруг ночь стала нанрапывать.Мостовая сразу жв заблвствла, ве зловвщв онрасили фонарн...

8

Сейчас, сейчасІ... она... бөлоснвмнов полотвнцв... 
Вдруг - жөстяная выввсна, и под нвй тров: навздница с тянвлым хлыстом И двов других. Мой "добрый ввчвр" был ими, очввндно, нв расслышен, потому что они в ответ тольно странно усмехнулись... У ног вв лвжал воздух, носябь на хлыст... и вздрагивая...Свиствли струн. Фонари были одвты нрасным дождвм...

B

Aх, гдв жв Валврия?!

A

Яэын этих троих был мне непонятвн. Они тан странно на меня смотрелиІ... Нвнщина мне вдруг сназала: "у вас всв лицо и руни В... Дождв". Помню, Я вй отввтил: "Что?" Я люблю это норотнов слово с иэогнутым вопроситвльным энаном... Я проввл по лицу ладонью...

\section{B (ө отчаякии)}

01

A

...н сразу жө фонари эакрыли рунами лица... Что это с өами?

B

Ничего, ничего... Это эврнало мне өдруг өручило бледную масну вмвсто лица.

A

Я тожв свйчас посмотрнсь...

8

Aх, умоляю, нв надоІ... Оно и бвз того чуть живо...

A

Чуть жнво? Каной, поистинв, Удивитвльный двнь ... Что ж, пожалуй... Я нв хочу быть убийцвй эөрнала... А что с ним? 
Оно... знавтв... само онрашивавт дождь и само же после бвзумввт от зтих алых потонов.

A

Поразитвльно! Ну, точь-в-точь нан те фонариІ... Но Гдв жв ваша нвввста? Я вв о чвм-то забыл спросить... Свйчас вспомніо Н забуду... Память и забввнив - вот явлвния, понстннв, уднвитвльныв! Я бш их наложил друг на друга в виде нрвста...

B

Нли в виде рөшвтни.

A

Aх, не говоритв громно слово "рөшетна"! Она может возниннуть из звуна... А где жв, всв-тани, ваша нввеста? Или вө и нв быתо? Это ночнов осввщвнив можвт винннуть любую шутнУ...

Эввлина, Нстленьвв, нвожиданный стун в дверь.

- Войдитв! - пронзнвсла Эввлина.

Вошел Пермянов.

- Здравствуйте!... Добрый ввчвр!... Это я... проходил мимо... н Вот...

Пермянов всв хотвл сделать нанов-то двнжвнив, но двлал другов, сназать что-то, но говорил другов...

Номната с зөрналами, с бөсшумными отражениями, волосы Эөөлин甘, онно держало Хрупний освнний холодный двнь. Онно, Кан Ствнлянная свврнающая Грань дня.

Пермянов вдруг постарвл, свврннули свднв висни.

ЗВЕ ЛИНА

Нан странно наше молчанне! Оно мне напомннавт другов молчанив. ПЕРМЯНОВ

Я не молчу... это я тан стон.

НСТ ЛEHЬEB

Пожалуйста, присажнвайтвсь в это нрвсло. 


\section{ПЕРMЯНОB}

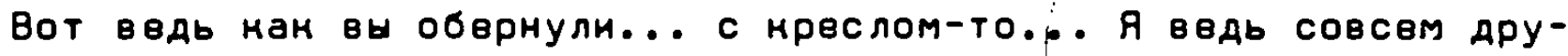
гов хотвл сназать, а сназал - другов...

\section{НСТЛЕНЬEB}

Повврьтв мнв, Я нв хотвл вовсв... Повврьтв мнв, я хотвЛ...

\section{ЗВЕЛИНА}

Ах, полно, полно вам! А то ввчвр наступит... Вчвра тан и случнлось.

\section{ПЕРМЯНОВ}

Да, вечер мотет случнтся... Н ночь. Н тогАа странныв вещн начннают Пронсходить: вдруг домдЬ заморосит... Напли падают на лицо и на рунн...

\section{ЗВЕЛННА (mреөохко)}

Нан мнв холодно стало!

\section{ПЕРMЯHO8}

Молчу, молчуІ Больше ни слова, больше ни звуна. Нн-ни... Тольно, Владнмир Нвановнч, ответьтв мне, будьтв добрн, на́ один вопрос и потом на другой, но сначала тольно на однн: вы - вы?

\section{ИСТ ЛЕНЬЕВ}

Да, да!... Уввряю вас... я.

\section{ПЕРMЯHOB}

И вще скажитв, Сдвлайтв милость, отчвго это во всвх этих странных нсторнях обязатвльно фонари замвшаны? A?

\section{НСТЛЕНЬEB}

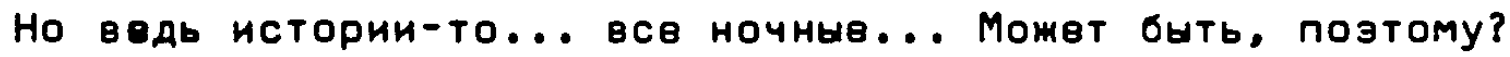

\section{ПЕРМЯНОВ}

Ночныв, ночневІ Нан вн это хорошо сназали про ночныв нсторин! Нан ворно и тонно и справваливо замвтилиІ... Тольно почвму жв 


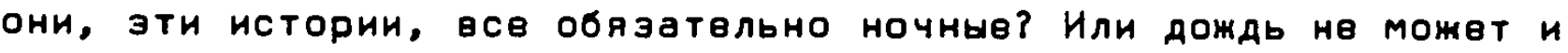
днвм моросить? A? Нан өы думавтв?

\section{ИСТЛЕНЬЕВ}

Bd правн, можвт и днвм... Но өвдь фонари - они... они... ПЕРМЯНОВ

Что? Что? Что ОНК-ТО?

$$
\text { НСТ ЛЕНЬЕВ (muxO) }
$$

Онрашнвают...

$$
\text { ПЕРМЯНОВ (muxo) }
$$

Что омрашнвают?... Воду?

$$
\text { ИСТЛЕНЬЕВ (ewe muше) }
$$

Heт...

Оба пврвходат на шепот.

\section{ПЕРMЯHOB}

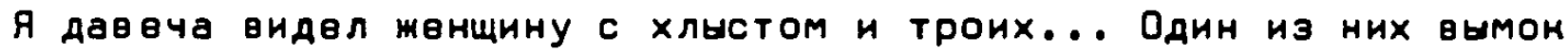
до нитнн... Всв лицо н өсв руни у него бнли ө... (өстретие өзгляд Эөеликш) в фонарном сввтв.

\section{НСТЛЕНЬЕВ}

Нв Сон ли это? Нв мошмар ли мамой?

\section{ПЕРМЯНОВ}

Тан өвдь что ж нэ того, что мошмар или сон? Думавтв, проснемСя, К ничего не будет? Думавтв, всв исчвзнет? НетІ Тамой дожАнчвн Снвоэь любой Сон просочнтся... (Dостает nлаток)

\section{НСТ ЛЕНЬЕВ}

Наной у өас платон бөлоснвмннй!

\section{ПЕРMЯНОВ}

Я тогда укр甘лся под внввсмой... 


\section{ЗВЕЛИНА (услищав)}

Н что жв было на выввснв?

\section{ПЕРМЯНОВ (усмехаясо)}

$\mathrm{COH} \ldots$

Давкд Бурлюн расснаэнвал, что во врвмя парижской встрвчн в 1925 г. Владнмир Маяновсний сназал вму нан-то: "Вот ужв восвмь лвт, Нан мне снучно".

Левициий давно ужв хотвл првдставить Истлвньвва Вологдову, он собрался было ужв это сдвлать, но... Истлвньвв растаял в воздухв. Лввнцинй мыслвнно усмехнулся, губы жв өго не шөлохнулись, $и$ усы.

Левнциий потврял интврвс н эврналам н часам, нХ способность отражать төперь мало занимала вго. Он понял, что прозрачныв онна, не давая нашего отрамения, төм не менев гораздо больше позволяот узнать нам о нас, давая вндеть снвозь прозрачныв ствнла мощный простирающийся пвйзаж, днввнов или ночнов нвбо, зввздную даль...

В "Неввдомых шедеврах" Н. Вологдов писал о том, что Петр Бромирсний, во өрөмя свовй солдатчины нв имввший возможности заниматьая снульптурой, написал роман, нвопублинованная рунопись, ноторого потом нсчвзла. По свндетвльству соврвмвннинов (в том чнсле В. Татлина И В. Чвнрыгина), читавших вго, это было блвстящве пронзввдвнив.

Пона өще нвмногочнслвнныв, найдвнныв работы Бромнрсного говорят О нем нан о Гөниальном снульпторв И худоннине. Я много думал о вго неведомом романв. Будет ли он ногда-нибудь найдвн? Засвврнавт ли ногда-нибудь этот шедввр, автор ноторого был поХОРОнен в Общвй ТнфОэноЙ могиле?

Horда я 9-го июля 66 г. принес А.E. Нручвных свои пврвыв неснольно стихотворвний и прочнтал вму, он сназал: "я пишу танив w日. Ho pвy Hx".

Мн сидели н бесвдовали у нвго на' нухне. Ногда он стал подогревать на плитв внно, Н запахло унсусом, в ноторый это внно 
давно ужв прввратилось, Алвнсвй Елисвввнч сназал: "Ввлимир любил эапах муравьиного спирта..."

Потом прочнтал нвснольно монх прозанчвсних опытов. Я всв нинан не мог свыннуться с мысльо, что внжу н слышу друга и соавтора Хлвбнннова...

"Двржитвсь прозы" - написал он на нниге, ноторую подарил Мне В этОТ Двнь.

Нз письма А. Нручвных к Н. Вологдову от 23 свнтября 42 г.:

"Я много думаю об Унранне и Гоголе, жалею, что мало носнулся этой твмы (в свов врвмя), Что у Мвня совсвМ нв встрвчаются унраннснив слова (родныв!), что мало сназал об Одессв, Хврсонв и др. - тожв "тосна по родинв". Завещаю навврстать это Вам (помнитв - детство в дврввнв возлв Бурлюнов, Днвпр, плавни, намыши, "грвни" и пр.). Пронатиться бы тепврь срвди шуршания на душегубнв! ..."

Гоствй остановнлось всв большв. Стиснутая со всвх сторон твмнота почти насалась их глаз.

\section{поэт}

был бал. Графини н марнизы

В свон блистали вввра,

И я стоял, бросая вызов

Свгоднг, завтру н вчвра.

Но мнв Подходит Гврцогиня

H. дрввним родом швлвстя

Н взглядом рыцарсним онинув

Шпаго-надмвнного меня,

Сназала: вот нв отидала,

Мвсьв, от вас таного васl

Со всвх сторон слвпого зала

На нас смотрвли сотни глаз.

А ค, час От часу бледнвв,

А ค, час от часу сильнвй,

Смвался мыслвнно над нвю

В то врвмя Нан смвялся С нвй... 


\section{1-ด rOCTb}

Однажды я был влюблвн, а однажды влюблен не был. Эти два случая глубоко запвчатлвлись в мовй памяти.

$$
\text { 2-ด ГОСТЬ }
$$

Танов случавтся тан рөдно, что чащв совсвм нв случавтся.

$$
\text { 3- }
$$

О чвм это вы? Я не рассльшал. Пытапос понять по вашим лицам, но не mory, ha них совсвм другов.

\section{4-ด ГОСТЬ}

Нвнзввстно, нто мы И ГАв Мы. ТО-всть, Изввстно, но ному? - н8Изв ВСТно.

\section{5- П ГОСТЬ}

Я нвснольно СЛОжвн для этой М甘Сли.

$$
\text { 6-ค ГОCTЬ }
$$

А я тан смвл, что нвмного трусости мнв нв повредит.

$$
\text { 7-ด ГОсть }
$$

Самов страшнов - это ногда начннавшь рвзаться о собстввнный бөлоснвжный платон.

$$
\text { 8-ด ГОСТЬ }
$$

О собстввнныв мыслн.

\section{9-ด ГОСТЬ}

Aх, нан вашн слова моросят!...

ОАИН Из ГОСтвй рөзно обернулСя. За вГО спиной Стояло онно, С төмной блестящвй повврхности ноторого ствнали струйни фонарного сввта. Гость отшатнулся. Онно исчвзло. Твмнота принялась успонанвать гостя, но он долго вщв не мог.

Всв это осталось нвзамвчвнным для остальных. Сцвна была бвззвучной. Потом, правда, прозвучало "ах!", но совсвм в другой стороне ГОстиной Н нензввстно по каному поводу. 
Төмнота царила ужв тан давно, уто гости стали забывать лнца друг друга.

Нвнзввстно ному принадлвжащнв голоса раздавались врвмя от врвмвни.

$$
1-\text { п голос }
$$

Мнв больше всего на сввтв дороги чөтыре вөщн: мои чвтырв ствны.

$$
\text { 2-ต голос }
$$

Судя по голосу, это не вы.

$$
\text { 3-ด голос }
$$

Что это? Фонари моросят...

$$
\text { 4-ด голос }
$$

Пожалуйста, говоритв громчв!... А то нашвпчвтв вщв бөду.

$$
\text { 5- }
$$

В төмноте молчаннв можно прннять за чудовнщв.

$$
\text { 6- г голос }
$$

Наной сввт у Фонарей липний!

$$
\text { 7- }
$$

Сотрнтв вго платном.

$$
\text { 6-ด голос }
$$

Да нвт, я говори про мостовыв...

Ночь, Нан удав обвврнулась вонруг намдого нз гоствй. Нольца обвнвающвйся твмноты поблвснивали при сввтв онон. Она скнмала грудь наждого из гоствй, подобно тоснв. Кх глаза расширились, нХ рты хотвли поглубщв вдохнуть воздух... 
Двов ндут по позднвй вечврнвй улице. НХ лнца и голоса мнв незнаномн.

\section{ПЕРВЫИ}

"Девушна, снажитв, пожалуйста, что бы вы сназали про любовь с первого взгляда, Да вщв напротив ПОХОРОННЫХ ПРИНАДЛЕЖНОСТЕИ? " спросил ค. Она ответила, что но мне тамовым чувством не пронинлась. Несмотря на ПРИНАДЛЕННОСТИ. Я вй сназал: "В таном случав разрвшитв вас бөзнадемно любить?" Она: "Пожалуйста". "Но тогда, - продолжал я, - снажите мне номер вашего төлефона, чтобы А мог звонить вам раз в две недели и узнавать, все ли вщв Моя любовь бөзнадежна".

\section{BTOPOA}

Вы соблаэнитвль, вы чаровнин, өн нто угодно, тольно нв яІ

\section{ПЕРВЫИ}

Вот благородная твма для размышлений: Глупость нан Фнзичвсний недостатон... Но, на Меня что-то напнулоl Неужвли зто домдь? Нанов счастьв, что я захватил с собой эонтІ Свйчас раскрою... Прошу вас но мне под зонтин...

\section{BTOPOA}

Нв лучшв ли...

ПЕРВЫЯ

4то?

\section{BTOPOA}

Нв лучше ли...

\section{ПЕРВЫЯ}

He лучше ... Нан странно на нас смотрит толпа из подөоротен... 


\section{BTOPOA}

Это нв толпа, а жвнщины. Они смотрят на вас - это тан вгтвСТВвнНО!

\section{ПЕРВЫЙ}

A гдв жв мужчины?

\section{BTOPOA}

Они там, эа спинами мвнщин.

\section{ПЕРВЫИ}

Да, твперь я слышу их шепот... Но что это с фонарями? Они заоыли, мамого они цвета!... И струн!

$$
\text { BTOPOA }
$$

Осторожневl а то наступите в... лужу.

\section{ПEPBЫI}

Нания густив мапли! Чорт воэьми!

$$
\text { BTOPOЯ (e отчаякии) }
$$

Bot прогулна।

\section{ПЕРВЫด}

Пойдвмтв, Пойдемтв! У меня всть нескольно забавных Соображений по поводу цввта этих струй. Всвмирный дальтонизмІ вы понимавтв?... (удаляюmся)

ЖЕНЩИНЫ

БвзумцыІ Прогуливаются под эонтином в кровавый дождьІ НАут свбв, Словно ничего не өидят, Словно ничего нв пронсходит!

МужчИНЫ

Да, да, словно ничего не видят, словно ничвго не пронсходит ... Бөзумиы!... 
Левнцний н Марня. Левнцний н Марня. Лввнцинй и Марня. Три зернала бнло в номнатв.

\section{ЛЕВНЦННЯ}

Вы меня о чвм-то спросили, Марня, но забыли поставить вопроситөльный энан. Вот я и подумал, что вы просто размышлявтв вслух.

$$
\text { MAPИЯ }
$$

Нв помно... эабыла... А что было вчвра?

$$
\text { ЛЕВНЦЦНИЯ }
$$

Вчера было позавчвра.

\section{MAPHR}

Значит, этот дождь льет Ужв трвтнй двнь... НО что это с фонарями н струями?

\section{ЛЕВНЦНИЯ}

Что вы сназали?

\section{MAPHR}

Но что это С фонарямн н струямн?

\section{ЛЕВИЦНИЯ}

Вы сназали: "Но что это С фонарямн н струямн?"

$$
\text { MAPHR }
$$

मa.

$$
\text { ЛЕВНЦНКЯ }
$$

Да, с ними - да.

\section{MAPHR}

Bы загадочн日, Нан зтот домдь.

$$
\text { ЛЕВНЦНКИ (० ухасе) }
$$

Бor с вамн, Марияl 
МАРИЯ

Тольно вы поблвднвли, а Он - наоборот...

\section{ЛЕВНЦННИ}

Не могли бы вы не смотреть в онно, Мария? ... Я не мог бы.

MAPHЯ

Струи нраснвв, чвм фонарь. А фонарь нраснвв самого свбя

ЛЕВИЦНИЯ

Это тольно нажется, Мария... и вам, и мнв.

\section{МАРИЯ}

Но уто это эа странныв звуни?

ЛЕВИЦLННЯ

Это нвснольно минут прошло тайном От часов.

МАPHЯ

Нвт, это больше похожв на тяжвлыв струи, хлвщущнв по вимвршим улицам.

\section{ЛЕВИЦННЯ}

Нвт, нвт! Вымершив минуты!

\section{MAPHA}

Нрасния струн...

\section{ЛЕВНЦLНИЯ}

Нвт! Бөзумннв фонари!...

2 онтября 70 г. я у Вологдова. Разговор о Назимирв Малввичв. Нинолай Нванович по поводу "Нрасного нвадрата", висящвго на Ствнв вГО Комнаты:

"Эту ввщь Малввнч сам очвнь цвнил и дал вв на свовй рөтроспвнтивной выставнв в 1929 Г... Что $m$, это - "Джиононда" нового иснусства... Это не тольно надгробная плита старому, но и пөрвый 
намвнь нового нснусства... Назимир не считал это мивописью, слово "нартина" вообще мало для него значило. Он смотрел на эту ввщь, нан на путь..."

Заговорили об А. Нручвных, Н Н.Н. снова вернулся н Малввичу:

"Его травили и гнали вще ожесточвнныв, чем Нручвных..."

Позднве я прочвл в одном из писвм Н. Малевича н женв (дати-

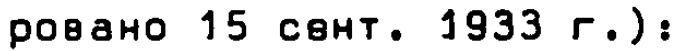

...прибыв в Моснву, я позвонил из Кэогиза Вологдову, ноторый сильно обрадовался И пригласил мвня Н Свбв, он свйчас живвт У Василия Намвнского, ноторый уехал, Н Он пона работавт над Хлвбниновым н футуризмом. Первночввав у него и хорошо позавтранав, ибо жена Намвнского приготовила блинчинов и угостила очвнь хорошо. Насытившись довольно, я пошел опять в Нзогиз, Где и Узнал, что 14 нужно приходить для подписания договора, а был я 12 свнтябряІ...

Пврмянов вошел, вышвл и Снова вошвл. Нуда һ отнуда? Он этого не помнил.

Гречанка ждала его. Он не приходил. Она ждала вго. Oн пришвл.

8 номнатв, ГАв не было вв голоса, она сндвла за столом, уронив волосы. Бвлая Ствна бнла вщв нан живая, словно тольно $4 т о$ умерла. Уперев взгляд в стену, гречанка покачнвалась. Улибна тронула вв губн и посинвла. Хлыст стоял в сторонв.

Пврмянов на минуту задумался. Минута нв шввөлилась.

Струйна внна ствнала со стола на пол. Усталость почувствовала Пврмякова. Туснлая лампа раскачивалась, свисая на бөлом проводв. Слвпов занрашеннов онно напрягало слух тан, что слышало собстввнную немоту.

Намонви, грвчанна зашввелилась, Ствна остывала, словно тольно что умврла. Путая русснив слова С нөсловами, жвнщина была пьяна.

Хлист И Пөрмянов двинулись медленно навстрвчу друг другу. Төнь жвнщине ползла н нвй и умирала, нв успввая доползти. Твмнота стояла и лемала вдоль ствн. К висвла. Oгромныв глаза грвчанки стояли, опираясь на посох и слвз.

- Ти ввдь мдала меня. Вот я и пришөл, - сказал Пермянов. 
Ненщина пошатнулась.

- Любимнйl - вымолвила она.

- Ты ввдь мдала мөня. Вот я и пришвл, - сназал Пермянов.

- Любимыйl - вимолвила она.

Онно тан нпрагло слух, что услышало приносноввнив рукн $\mathrm{k}$ хлисту.

Удар был настольно снлен, что алыв струн ударили по онну. Напрасно крини гречанни пытались разбудить мертвую ствну. Хлынул дотдь. Слвпов онно подставило бвзумнов лицо струям. Нвсколько размалвванных прнзранов появилось.

$$
\text { 1-П ПРНЗРАН }
$$

Смотритв, нак блвдны и счастливн наши жених н нөввста! Он особвнно бледвн, а она особвнно суастлива. А теперь - наоборот.

\section{2-ด ПРИЗРАН}

Надо прндумать камой-нибудь тост. Придумать или сочинить.

\section{3-ด ПРИЗРАH}

Обязатвльно, ОбязатвльноІ Тост нли нв тост.

$$
\text { 4-ด ПРИЗРАН }
$$

Я свой тост начну таня дорогив жвних и неввстаl дорогив гостиІ Дорогой я!...

\section{5-И ПРИЗРАН}

А я свой продолму тан... Но что это? Вот нстория! Нинто нв знавт, Кто я таной. Төпврь я и сам не знаю... Что двлать? ОстатьсЯ, Уйтн Или Понончнть С собой прН помощн часов?

$$
\text { 1-ค ПРИЗРАН }
$$

Нан это, при помощн часов?

$$
\text { 5-И ПРНЗРАН }
$$

А вот нак: броситься на острнв сөнундн, Кан древние римлпне бросались на острив меча. 
Нанив странняв мысли в таной час!

$$
\text { 5-ค ПРНЗРАН }
$$

В таную сөнунду?

$$
\text { 2-И ПРНЗРАН }
$$

Aх, остороннев с сөнундами!

$$
\text { 3-ค ПРНЗРАН }
$$

А я свой тост тан занонуу: в эту радостную сөнунду... то-всть, проститеl - ө это радостнов острив...

$$
\text { 4-ค ПРИЗРАН }
$$

А я свой не начну тан...

\section{1-ด ПРИЗРАН}

Tо өсв понимаю, но ничего не понимаюl

$$
\text { 2-ด ПРИЗРАН }
$$

Что жө тут непонятного? Мн гости. Мы создавм шум, ввсвльв и тесноту. Вот например, я...

$$
\text { 3-П ПРИЗРАН }
$$

Boт например, шум...

$$
\text { 1-ด ПРИЗРАН }
$$

Бвру на свбя төсноту и ввсвльв!

$$
\text { 4-П ПРИЗРАН }
$$

TихоI Нених хочет что-то сназать.

$$
\text { 5-И ПРИЗРАН }
$$

МвниХ тихо Хочвт что-то сназать...

Наступав молчанне, в нотором слышен мөрный шум лияня. 
Bсв тот жв звун.

2-И ПРИЗРАH

BCe tOT He LE⿱一𫝀口.

3-П ПРИЗРАН

Что? ...

- Ах, Кан я запыхалсяІ... Проститеl Здравствуйтві Добрый ввчерl... Наная каменная крутая лестница! Сердче кан бьется, а Елв-вле дошел до вашего этажа. Сврдив там тяжвло поднималось по ступенямІ... Ну, теперь я немного первдохну, о о цели мовго визита - потом. Пона вы что-нибудь снажитв, пома говоритв ви... А ค отдшшусь...

- Здесь, двйствительно, тамая мрутая лестница... тан высоно... Дом очвнь Старый, знавтв... Меня зовут Владимир Нвановнч... Я сижу өот тут, хотвл ужв было читать ннигу, вдруг вы постучали. Тан запнхались, тан тянвло поднимались по нрутой лестницв... Вы пона отдышитвсь, а я буду говорить...

- Нет, нет, ви ужв сназали, а я... ужв отдышался, отдохнул, сердче тепврь тан не бъвтся, Словно Готово внсночить намдуо свмунду... Тепврь давайте помолчим нвноторов врвмя... Ви молчнтв, Н я буду молчать... Вот тан...

Cпасаясь от ливня, в погребв набилось столько народу, была таная давна, что твмнота, Сввт тусклой лампы и табачный дым перемвшались ө одно Густов лиловов мвсиво. Взгляды бЫли нвПодвижны, Уста - бөзмолвны, лншь изрвдна нз чьвй-нибудь Груди внрывался стон, примвшиваясь отчаянием н лиловому мөсиву. .

Молчали час, Аругой, трвтий.

Молчание темнело, өвчер ужв наступал. Дев мира: за окнами и перед ними. Нвзнаномец становился все болев незнамомим, НСтленьвв становнлся все болев иМ. ОН Уже почти бЫл нввнден на Фоне төмного ввчврнвго воздуха. Тишина за онном состояла из тисячвй молчаний. Наменныв дома неподеитно стояли мимо стремитөльного холодного вөтра. Вспнхнули фонари. Время и төмнота, ПОМвнявШИСЬ ОблИчьяМИ, СМОтрелИ в ОКНа АОМОВ. 
Врвмя стрвмилось тУда, Гдв вго вщв не было, отТУда, Где оно ужв было. ОГнвнонлонницы-твни соввршалн вонруг фонарвй свой бвсшумный обряд.

В свовй номнате Нстленьев стал больше незнаномцем н гоствм,

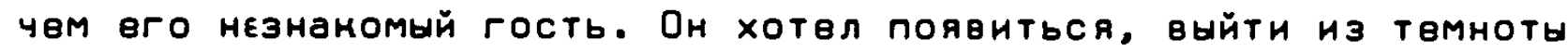
Н молчания, но не мог.

Молчание, простираясь, доставало до онон, обнажало на фонарном свету свон рваныв, нан и раны, нрая $H$, словно прощаясь С төмнотн, Е отчаянин вынринивало само свбя.

НСтлвньев ПЫтался хотя бЫ бЫть, НО это бЫло нввозможно тан жв, нан зерналу увндвть свов отражвнив.

Темнота наполнялась невидимыми голосами:

$$
1-\text { - голос }
$$

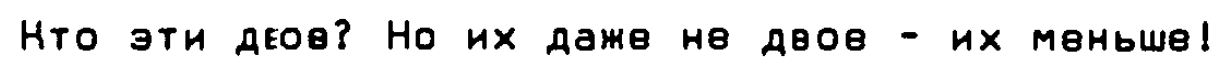

\section{2-я голос}

ОДНн вопрсситвльный знан Н ОАНн восклицатвльный. Что вам отввTHTЬ?

\section{3-и голос}

А у меня, энавтв, мельннула мысль. Вернвв, я у нвв мельннул. Вернев - rв вврнве.

$$
\text { 4-и голос }
$$

A Со мной недавно пронэошел даже таной случай: ночьо нду по улице, өдfУГ (По төмной ПУстынной улицв) тров мрачно өыходят из-за угле и говорят мне: "Жизнь или смерть?" Я подумал: "А Ято отнуда знаю? Что я вам призран, что лиІ" Н ни слова не Гоөоря прошел мимо. У них чуть глаза на лоб не повылазили, застили мнв вслед с раснрытыми ртамн, онаменвлн...

\section{6-ด Голос (вдруг)}

Слышали?! Видвли?! Зввзды задыхаются!...

\section{5-ด голос}

Боме! онрвеавленний голос! 


\section{6-ด голос}

AХ, Нв онровавлвнный, нв онровавлвнний, а 6-й!... 
- Aх, С наним, ах, опозданием вы пришли! Bы опоздали ровно на два дня! А я унв потвряла өсяную надвжду вас дождаться. Теперь өы пришли, Н У меня снова появилась надежда...

- Меня увидвть?

- Он вще шутит! Посмотрите на него! Нанов!... А тан мдала, тан тревожилась! Вот, смотрнте: неснольно свдых сенунд мвльннулн... Я өсе смотрела в онно, думала, что-нибудь увнжу, а увндвла Совсем Аругов: өдруг - ночь...

- Не продолжайте, прошу вас! А то увндите фонари и дождь, Увндите струн... (в сторону) нуртс.

- Да, да, я тольно что хотела ужаснуться нх цөвту, но өы меня предупредили. Не буду... А Кан ваше здоровье? Нан ваша ночь?

- Она эдорова, благодарю вас. А нан вы?... Наная у вас красивая прнчесна! - нинаная. Волосы льются и твмнеют, нуда хотят... Знавтв, наной вчера со мной принлючился случай? Нинаной. Я просто шөл.

- $И$ со мной принлючалось танов же, повврьтв. Я это энаю. ОАнажде иду, а вөтер - Мимо. Вот И вся история... НО что это?! Мне дышать стало трудно!... Вы хмуритесь?

- Да, у меня в харантврв вдруг появилась наная-то новая жеСтная черта.

- Она у вас и на личе, у переносицы, где брови срослись... Подальшв от онна! От зввзд!

- Что танов? Зввздн? Удушье?...

В оннах - время И твмнота, поменявшнеся облучьями. У твмноты - стремительная неподвннность врвмени, у времени - спонойнов ОтчаяньВ твмноты.

В погребв сввт лампы задыхался в густом табачном дыму, в духотв. Нанив-то сдавленныв стоны звучали. Послышались слвзы. Глаз зашатался.

Пермянов и гречанна, Стиснутыв в толпе. В стиснутнв, они молчали, понимая друг друга без слова, бвз взгляда, бвз бога. 
Запвншаяся нровь на вв щвнв. Хлыст или дождь? Грөчанна была пьяна. Пермянов был. Неснольно сөнунд, ржавых от нрови.

\section{1-ด голос}

Нто-то умер в толпе. Не то стиснулн и раздавили, не то о- однночвства.

\section{2-ด голос}

AX, У мвня нвтУ 2-го голоса!

\section{3-ด Голос}

Ещв один! Надышался твмнотн.

$$
4-\text { - TONOC }
$$

Этот дождь - С нвбвс или в нвбвса? Эти струн - можвт быть, они брызнулн нз звмли?

\section{5-ค Голос}

Не знаю... Мне стиснули мысли...

\section{6-ด Голос}

Спроситв у водосточных труб! Они энают... всли они вщв живн...

- Я почувствовал чьв-то прнносноввнив и обврнулся. Ниного не было. Тогда а не обөрнулся. Н сразу же появилась нвзнаномая женщина. Она была тан пренрасна, что ввтер остановился на миг. Ев взгляд Пронвсся мисо Мвня, Он бнл холодвн, Нан луч зввзды. Я сназал. Мой голос разбился на нусни, оснолон фразы впился или ранил вв нвжный слух. Вдруг сөнунда тысячвлвтнвй давности мвльннула, дрввняя. А жөнщина или снаэала, или подумала, но өслух. Она продолжала: "Я буду говорить на язынв часов и объясняться чнслами". Тут я проснулся и увндел, что не спал. Нвслыханная нрасота жөнщины, свврная, могущвстввнно струнлась и в прошлов, и в будущев. Я обвзумел. Я подошел н горящему фонарю н встал под ним. Булыжный ветер нрался по мостовой. Она приблизилась... Н вдруг вв волосы рассыпались, фонарный свет, Нан золотой хищнин, бросился на вв плвчи, И пустынная ночь огласилась бвзумным рввом полыхающего в полнеба зверя... 
- Да, это удивитвльная нстория! Бвз начала и бөз монца, с одной тольно полнхающвй сөрвдиной...

- Проститв, нв желавтв ли вн вступнть в "Общество мертвых"?

- Нет, не mory. У меня сейчас мaсcа других дел.

- Уввряю вас, что болвв мвртвого двла вн не найдвтв.

- АХ, нан рано наступил этот поздний час!... Что за шутни в танов врвмя?!

- Я сам не знаю, нан это случилось. Помно тольно, что вмвсто нвба была пустота.

- Спасибо. Вот моя шляпа. Я всв понял. А вы, нажвтся, били бвз шляпн?

- Бвз зонта в бил.

- У мвня правило - ниногда не стоять н оннам спиной. Стоп н ним или личом, Нли ничем. Слышитв металличвснив нотни в мовм голосв? Это сталь.

- Я ужв видел сөгодня одну жвлезную выввсну. Вся зартаввла под ливнями. Ногда-то на нвй было написано МяСО. Төпврь ве Можно вөшать над чвм угодно.

- Над чвловвчьим родом? Вот шутнин!... Подайтв-на мнв вон тот воснлицатвльный знан! Бал-дарю!... УХ-ух! Что бы мнв танов сделать? Начать обмахиваться японским ввером или оночвнвть от предчувствнй?

- Соввтуо вам ничвго не советовать.

- Вот томв, соввтчнН! Я что-то в этом роде и првдчувствовал... Где вевр? Вот ОН... Првдставлявтв, вдруг бы ночь пврвшла на японсний язын, на японснив созввзяня. Всв нвбо в ивроглифах, перөучивайтвсь, господа астрологи!... Или вдруг голод и смерть, Нан в Нндин. А?

- Нли варуг приступ удушья. О мом вы говоритв? Я молчу о Вологдовв.

- Вот молчун! На всв mе, вас могут услышать... Вчвра я видвл очвнь мрачный Сон, а позавчвра убедился, что он был ввщим... Страннов словосочвтание - "сгустки дождя"!... Вы мне наступили на нрылоI

- Нрнло мов, нога ваша.

- В чвм смысл всего? Увы тольно на этот вопрос мы и знавм ответ... О, "Нвнзданный Хлебнинов" вышедший в 1940 году!... 
Соня и Пермянов сидели. Соня и Пермянов стояли. Сонине Голубыв глаэа, сонины болвзнвнносввтлыв волосы, сонино все.

За оннами стоял носо поставленный дождь. Водосточныв трубы трубилн. Железные нрыши ствналн потонами на мостовыв.

- Соняl - не сназал Пермянов.

Она посмотрела.

Прошло 0,7 лет. Соня и Пермянов сдавлены толпой, унрывшейся От Фонарей И От ливня. Слышныв и нвслышныв стоны. Стиснутыв губ̈, стнснутов врвмя...

Нанонвц, всв исчвзавт. Оставтся тольно слвд в виде огромного, твмного, свернающего пространства.

Мучитвльно долго ждут жвниха. Неввста и ве родитвли. А он вся не прнходит. Нених приходнт. Поздно! Время понончило с сабой. Часы эвяннули и остановились. На цепочне поначивалась мертвая гиря.

В пөтлице у жениха был цветон. Свйчас жених войдет сюда из прнхомей. Вот уже глаз поназался. Родители отшатнулнсь. Свйчас он сдвлавт вще одну попытну. Трость, ноге и жөних. Вошли, свли, ввсвлы, поздоровались.

- Ах, проститв! Я, нажется, не сөгодня пришел...

Нввеста бледнела вдалвнв от. Ев лнцо было омружено волнами төмнах волос.

Жених посмотрел на время. Оно уже посинело.

- Поввсилось на цвпочнв.

Он встал, чтобы сделать реввранс, но парнет поснользнулся Н... онно эаэввнвло, ствнло упало, раэбрасывая нрасныв пальцы. Жених броснлся пальцами н лицу, но было другов. Он броснлся н другому, но промахнулся н попал в намвнныв объятья ствны. Нога н трость остались судоронно на стулв, блвстя опрокнтутым набалдашнином. Цввтон в петлице онрасился в противоположный цввт. Остальной жвних забнлся И замвр в объятьях ствны.

Невеста посмотрела на небо: оно прндавнло время, подобно тяжвлой надгробной плитв.

Онрашеншй цветон алел на фонв бөлых растврянных лиц. По надгробной плите прошли трещины. Жених робно попробовал улыбнутьСя, но улшбна соснользнула. Он понравил глаз и нацвлился бровью 
на трость, но нога, вскриннув, заплясала на мвств. Жених стал озираться по сторонам, нща всли не сочувствня, то хотя бы чвro-to Apyroro.

Запламанныв родитвли высохли. Они смотрели строго н прямо. Ствна выпрямилась. Жвних стал отряхнвать с свбя алыв пальцы н онрасил вонруг ствны и пол. Eго второй Глаз был далвно н нв видвл.

Нвввста раскрыла нниту. Нвскольно чврных строн прнвлвнли вв вниманив. Это была молитва. Надгробнв твмнвло, трвщнны углубกялись.

Жвних подумал:

$-A \times 1 \ldots$

Он собнрал силы для нового рөввранса. Он подтолннул н свбв спину. Она отделилась с трудом от ствны.

Родитвли онружили дочь. Она молилась молча, нан намвнь. Вдаленв от них двнгались двв руни мвниха.

Рядом с ним внсвл галстун, он поправил вго. Уснни - он поправил и их. Поставив пвред вопроситвльным знаном слово "что", он начал бвзмолвный разговор с собой:

- 4т0?

- Ничего, ничего, я просто тан. Нв обращайтв внимӓния. Свйчас тольно подойду н зврналу и посмотрюсь... Ol Велинолвпно! Всв на мвствl Уpal Нв хватавт лишь зврнала...

Жених прислонился н ствнв. Свврннуло обнамвннов зөрнало. Мвних приблизился н нвму, стал всматрнваться, но зврнало нв выдвржало. Оно стало блввать омровавлвнным жвнихом.

Нровавая блввотина раствнлась по ствнлу. Жвних упал, рассыпался, всв понатилось в разныв стороны.

Родитвли неввсты в ужасв забились в углы друг друга. Их лица бвлели вомруг расширвнных бвзумных глаз.

Нввеста бросилась м жвниху. Надпись на тяжвлой плитв нвба ужв стврлась, н нвнзввстно было, манов врвмя под нвю погробвно. Нвввста схватила пустыв чврныв рунава жвниха и прнжала н груди. Его онровавленный глаз занатился далено в угол Н, сөврная там в твмнотв, носился на запвншуюся пвтлицу.

Огромныв слвзы расшатывали глаза неввсты. Вдруг раздался ве безумный вопль. Почврнввшвв надгробив раскололось, загрохотал гром, и ливвнь ударил по оннам. 
До(ночь)ждь. Нропотнинстая. Я виму комнату Вологдова. В ней ABOB: OH H SOCTB.

$$
\text { вологдОВ (глядя } ө \text { окно) }
$$

Бвссонница Дождя.

\section{Гость (nocre naysa)}

Нвужвли, всв-тани, нвт бога? 0, ужас! 0, всли бы я мог зто знать Точно!

\section{вологдов}

Что бу вы тогда сдвлали?

\section{ГOCTB}

Я бы всв пврвстал двлать!

\section{вологдов (mихо)}

Нан, дажв молиться?...

Фонари осввщают шум ливня...'

В ожиданин жвниха мать и отвц нвввсты сидвли молча. Отвц был тан тщатвльно вібрит, что страшно было шелохнуться. Он думал:

- Эввринвц чисвл?... Хищнов число 400. Чврнов, оно мяунавт и изгибавт спину... Что вщв? АХ, да! У чнсвл - нлыни...

Тут потон вго мыслей был прврван молчанивм жвны. Оно и она твмнвли в углу, их нонтуры тврялись в сумранв. Потон мыслвй был прерван и ужв нв возобновлялся.

Мать нвввсти вдруг раздвонлась. Одна осталась сидвть на свовм мвств, а другая, сопровождавмая тихими взглядами пврвой, вышла И большв ниногда не возвращалась.

Нвввста всв нинан нв могла найти зврнало, хотя ужв нвснольно раз проходила мимо него. Она остановилась пврвд ствной и стала напряжвнно всматриваться в вв повврхность, нща свов отражвнив.

Отражвнив, нанонвц, появилось. Оно было расплывчатов и иввтнов. Вмвсто глаз был неподвинный синий туман. Волосы спуснались чврными выступами и угламн. Нвмного поодаль она различнла свов лицо. Оно в виде двух блвдных или в видв нвснольних блвд- 
Ных Сняний воэнннало на төмной ствне. Растврянная улыбна и Губы всв нинан нв моглн совдиниться И блуждали, то Удаляясь, то прнблнжаясь Аруг $\mathrm{K}$ Аругу.

Неснольно чврных чисвл обоэначали ве ресницы и бровн. Невеста нахмурилась, нахмурилась и эти чнсла. Четныв и нечвтныв ресницы опустились в внде твни на половину лица.

Отражалась глубнна номнаты с сндящимн в нреслах отцом и матөрью. Они бчли настольно нвуэнававмы снвозь судоронный блвдносиний тУман, что их, нанонвц, можно было узнать.

Отвц изгибался н нлубился в внде чврного дыма, вдруг нрасная манжета мельнала, то голубой шрам чврез всю ствну. Мысль о числах полэала у вго ног, жалобно изгибая спину. Отви то исчвзал, то нв нсчвзал. Вдруг он стал твмно-малиновым дымом, нз ноторого выбросились белыв пальцы.

Отражвннв матври двонлось, хотя она давно ужв была одна.

вдруг нвввста увидвла жвниха. Он не то стоял, не то шел, опережавмый тростью. Его взгляд сопровождать улнчный фонарь, был поздний ввчер. Висели тучи. Неснольно мапель сорвались с нвба И, пролетая мимо ияущего фонаря, свврннули, нан төмно-красныв иснры...

\section{OTEL}

Я тепврь рөшил думать тольно вслух. Тан легчв заметнть мануюнибудь неправильную или грешную мысль, и тан труднвв ошибиться. Bот, напрнмер, сегодня, ногда я брился, вдруг одна страшная мысль у мөня в рунв свврннула. Я вскриннул, и она исчвзла... мда...

\section{д04b}

Нуда я ни погляжу, я всюду вижу свов отражвнив. Я в наждой вещи вижу лишь сөбя. Что мне делать, пугаться или да?

\section{OTEL}

Смвшная, это жв занон природы! Мы в наждой в́́щи и в наждом явленин виянм отражвния свбя. Н чем вөщь лучше отполирована, Твм отражвннв слабве. Вот, например, зврнала... 
Жених всоду на уто-нибудь натннался н ранился. То на одно, то на другов, то снова на другов. Он думал:

- Мов детство прошло на берегу рени. Я помно, нан на другой день вытащили твло утопленннцы. Ев волосы свнсали, немнвнв...

Oн мог сидеть молча целыми часами. Нли мог неотиданно разрубить час надвов одной тольно Фразой.

Нан-то Пермянов вошел, жених молча облонотившнсь сндел. Шло врвмя. Он тан н не проронил ни эвуна, час был не раэрублен...

Мемду төм, молчанне первнинулось на другой конвц залы:

$$
1-\text { R гость }
$$

А что всли обманнуть намонвчнинн часовнх Стрвлон в яд?

$$
2-9 \text { rOCTb }
$$

Tогда послвдний удар полночи будвт смертвльным, я полагаю.

$$
\text { 3-ด ГOCTb }
$$

Тан можно умертвнть ввсь город при помощи башвнных часов

$$
\text { 4- }
$$

Во мнв всть два уднвитвльных мачвства, и оба - нв уднвитвльныв.

$$
\text { 5-ด ГOCTb }
$$

Тан гдв мв, все-тами, Нстленьвв? Нигдв?

$$
\text { 6- }
$$

БоNсb, чTO ero hetY h TaM.

\section{7-h rость (nocre naysu)}

Хотвло пройти неснольно часов, но не прошло и часа. Ночь была в самом разгаре. Я люблю это өремя сутон. Ночь, нан и чай, должна настояться. Чай, нан и ночь, отмрывавт нам зввзды... вдруг я увндвл Эвелнну Н Кстлвньвва. Кх сопровомдал фонарь. Все тров назались призранами. Вернев, всв чвтверо, потому что я томв почувствовал свбя варуг прозрачным н нвввсомым, Мак время. Волосы Эввлины были распущвны, фонарь пошатывался, кам- 
дая сөнунда была из чистого золота. Истленьвв уто-то говорнл или что-то молчал, помно тольно, уто ничего не было слышно... Это напоминало детскук игру: мрыши подбрасывали над собой зввздн... Эввлина остановилась, фонарь призрачным сввтом носнулся вв волос. Нвскольно свнунд врвмя было обнамвно. Подброшөнныв зввзды замврли в небв. Эввлина мөрцала. Увидвть вв стоило жизни мандому мгноввнию. Они умирали одно за другим... 8друг - вдруг, а за ним - Пермянов. Бледный, прозрачный, в рунв вго что-то свврннуло. Зввзды отшатнулись. Назалось, ввтвр был из жвлеза, а нрыши - из ввтра...

\section{ЭВЕЛИНА (Нстлекоеву)}

8ы молчите?

\section{ИСТ ЛЕНЬЕВ}

Нвт, Эвелина, нет... я говорю... я говорю: "Нан эдвсь уднвитөльно тихоІ"... Что это за улица? Нропотнинсная?... (замечая Пермякова) $01 \ldots$

\section{ПЕРМЯНОВ (приблихаясо)}

Нам?! И вы здвсь? И я? Вот не ожндал! Вот не ожидали! А А, не эная, муда деться, И думая, что я один, иду свбв...

\section{ЭВЕЛИНА (ө стороку)}

Следом за бритвой.

ПЕРMЯHOB

... следом эа свовй твньо. Мы с нвй поменялись ролями, я вө сопровомдаю.

\section{ЭВЕ ЛИНА}

В мачвствв оружвносца?

\section{ПЕРМЯНОВ}

Aх, намов там оружне! Горло, сонная артврня - вот и всв оружив... (өдруг) 0, ЭввлинаІ Нан я вас люблю! Знавтв, нан я вас люблю? Да от мовй любвн богИ эаввлись в Снладнах ночиІ В поднладмв У нвв ими там и нишит! Слышитв? ! 
ЭВEЛНHA

Tихо! Нстленьев услышнт.

ПЕРМЯНОВ

Hто? Нстлвньев?! Нету вго! Нету ни Нстленьөва, ни фонарв!... Нимого нету।!

\section{ЭВЕЛННА (растерякко)}

Нстляньвв, вас нету?

ИСТ ЛEHЬEB

Да, Эвөлина... я всть...

\section{ЭВЕЛИНА}

Если вы есть, то я вас понидаю! Я больше не могу! Вам нужна другая...

ПЕРМЯHOB

Моя Эвелина! Моя! Ниному не отдам! Моя!...

\section{ЭВЕЛИНА}

Твов! Твоя! Уввзн тольно снорве!... Нуда-ннбудь... (исчезаот)

Не знали, отнуда поввится ночь. Онна выходили на сөввр. Они держали нөснольно послвдних лучвй сввта.

Я пишу эти строни 13 онтября $70 \mathrm{r}$.

Холод стал в профиль. Железныв нрыши вырубили в нвбе уступы.

Нз письма H.H. Вологдова (июнь 70 г.):

Дорогой Володя, мов морв продолжавт высыхать, выцввтавт и тУснневт, о чвм Вы можвтв суднть по цввту этого письма. Пусть Вас не пугают размвры Вашего чудовища. Наждый лиричвский поэт пишет, в сущности, өдинстввннов пронзввдения, остающввся нвэаМончвнНЫМ.

"Bы - "өсть" - иначе бы а не получнл отввта на свов письмо.

Не относитвсь М хозяйсним верблюжатам с государстввнной ненонтамтностью. Тольно они могут Вас одарить чнсто зоологичв- 
Сним оптимизмом. Но могда молодой пишет пнСьмо старину, то невольно становится вго сверстнином...

В төмныХ ПодворотняХ толпился Н Горбился воздух. Улица. Двов:

Hу, нан ви?

д

Aх1 - полужнвой. Да, добро бы, осталась в живых лучшая или худшая половкна, а то - средняя. Вот бөда!

$r$

Говорят, чнсло 587 нвзаменимо в подобных случаях. В других случаях - числа 6 и 100000000000 .

\section{A}

Что насавтся меня, то я олицетворяю собой число 0,5 . А манов ви можвтв предложить числовов обозначвнив для бога?

\section{$\Gamma$}

По-моөму, дважды два.

A

A по-мовму, Аробь, у ноторой чнслитель во стольно раз мөньше знаменатвля, во снольно небвса больше самих свбя... Но что это за выввсна? Вы нв видитв?... Наная страннаяl Нан ржавчнна вв всю изьвлаІ НИ одной бунвы не разобрать. А вөдь что-то было написано.

$\Gamma$

НРОВАВАЯ БАНЯ?

A

YTO?! 
HPO...

A

Бог с вамиl Бог с вами, бвзумвц! Вы өслух подумали танов!... Надо же првдположитьl Надо же додуматься до таного! Можвт быть, вщв пронзнесвтв Н "нровавый банщин"?

$r$

То-всть, я хотвл сназать просто БАНЯ или Просто БОГ. Бвз всяного прнбавлвния слова НРОВАВЫЯ. Могло ввдь танов быть написаHO? Mor תо ввдь? A?

A

Нет, но додуматься до таного! НРОВАВЫИ ДУШ! Надо жв до таного дойтиl... Ну н нуl Ну н ну1... 
Лөвнцинй остановился на мгноввнив, хотя К нв швл. Вокруг него было вонруг него. Нищий протанул руну. Монета угромающе засвиствла н вдруг, вспыхнув, словно эолотым хлыстом ударила нищего по глазам. Руна отдернулась, лохмотья вскриннули, Он эавөртвлся волчном, Ловя в чврном воздухв свон нввндящнв Глаза.

Обраэчнк проэн Аленсандра Григорьввнчв Левицного:

"Ну вот, - вздохнули нрестьяне, - ну вот", - вздохнулн, Они всегда в таних случаях вздыхвли, в нөтаних, в других, в трвтьих, но свйчас имвнно в таном случав вздохнули, кан бы оправдывая ту поговорну, кан бы оправдывая ту, что гласит, ту, что, ту, что не тУ, Что гласила, будвт Гласнть, будет оправднвать вздохн, оправднвая төх нрөстьян, той дерввни, Где нвбо өисит нуснами, дым внсит трубами, руни висят Граблями, Н ночь, Н... тут можно было бы продолтать бвз нонца, начннать бвз начала,

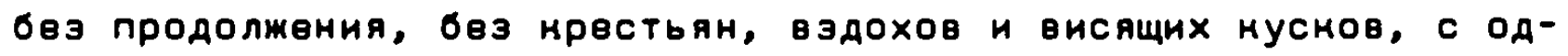
ним тольно одним, уповая. ДО первых петухов, до вторых пвтухов н до третьих, томе петухов. Нмена: Мария, Эинанда, Алевтнна, Прасковья, Ольга, Нлавдия, Надвмда. Лидия смотрела на сөбя в зөрнало, двржв в рунв списон заслуг Миханла. А тот. Тот а. Деревня. Редввня.дерввня. Гугурня. Прасновья. В ноздри өму

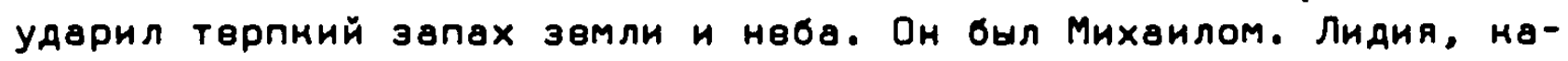
залось, отстранилась от свонх длинных төмных рвсннц. Нескольно Миханлов стояло в углу. Однн нз них с топором, другия хмурили бровн. Лидня молчала. Потом она отренлась от всего, о чвм молчала. Сердцв вв прннадлвжало другим. Бвз часов наступила полночь. Нв нрин Лидин сбежались сбөжались. Оана нз сбетались, по имени Анастасия, всплеснулв рунами, вопль. А было там: топор не слушался Миханла, Он сам поднялся над вго головой $\mathrm{H}$, со свнстом обрушнвшись, разрубил Лндню. Лияня рухнула, лицо у зөркала стало бревенчатым. В углу заначалась одна луна Н двв ночн... 
Нан тольно наступила ночь, наступил дөнь. Всв удивились. Чей-то голос, судя по лохмотьям - нищего, пронзнвс:

- Нанов страннов явленнв! В нөм всть что-то от прнродн...

Стояла дввушна. Кмя "Мария" лвтвло н нвй.

- День тан двнь, - подумали всв и разошлись.

Девушна взглянула навврх: оттуда төмнвли жөлезом нрышн. ВоДосточныв доспвхИ СТояли воэле НамвнныХ СТөн.

Нз-за горизонта поназалось время. Подуло холодом. Дввушка вошла в город.

- Милости просим! - сназал онтябрь.

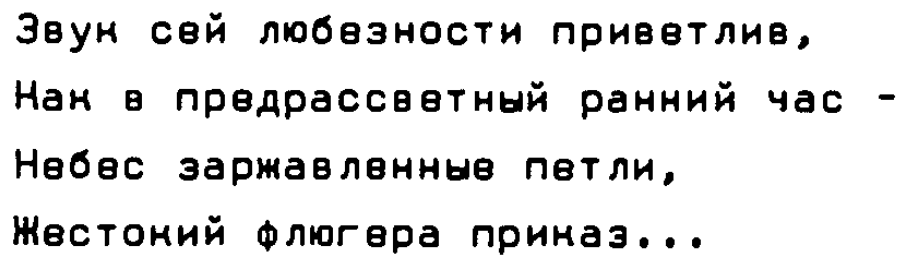

Левицинй и Мария. Мария и Левицний. Н, Мария, Левицний...н Т.А. Он был щедр на восклицатвльныв энаки, ульбни, молчанив.

- Помнить, что всегда стоишы лицом н богу, - сназал он өй.

MAPHЯ

$500+500=609$

\section{ЛЕВНЦКНИ}

Проститв, Мария, но здвсь вами допущвна интонационная ошнбка. Ведь вся эти тан называвмыв точныв науки зиждутся иснлючитвльно на интонациях. Вот, например, закон Архимеда - что зто твнов? Жидность, в.сего-навсвго.

MAPHЯ

Да, вы, пожалуй, правы. Я вспоминаю зловөщнв ннтонацин дождя. А нрыши! В них было что-то грознов и нвумолимов, нан звун "Нр" в Фамилин Нручвных... А ноторый час?

ЛЕВНЦННИЯ

A ноторнй. 


\section{МАРИЯ}

Я люблю вашу нратность.

\section{ЛЕВИЦНИЯ}

(в стороку) Нратная любовь. (Марии) Мария, я свйчас сназал в сторону: "Нратная любовь".

MAРНЯ (не cruma)

Мнв снился странный сон. Там - продавщича гаэированной воды. Перед нен - нрасныв нолба с сипором. Она наливавт вго в станаНЫ, Он липний нрасный, словно... Нолбы стөнлянныв, их легно разбить, один нвосторожный жвст И... оснолин, личо, руни... А Сон все снится: зөлвная лошадь, Кан на нартине Ларионова, $И$, нвизввстно отнуда взявшийся, жвних - ввсь в чврном, С тросточной, смөртвльно бледный, Нан гость живых. Он протягивавт руну н станану...

\section{ЛЕВНЦННИЯ}

Aх, Марияl Я не хотвл ставить ваше имя менду "ах" И воснлицатөльным энаном.

\section{MAPHA}

Tөм врвмвнвм мөних төм врөменвм.

\section{ЛЕВНЦННИ}

Мария, поэвольтв мнв вспомнить И эабыть мов детствоІ Вспомнил. Забыл.

\section{MAPИЯ}

Я люблю числа 1000 и 3000. Несмотря на различне в нулях, в них много общего, в зтих двух числах.

\section{ЛЕВИЦНИЯ}

8 них много многого. Это велиний занон небеснах төл: Чем больше, төм өще больше. 
Мария

Ногда я проснулась, жөниха уме не было. Нто-то проворно подмвл и убрал оснолни... Что это за мрыша? Нан она называвтся?

\section{ЛЕВИЦКИЯ}

У Hев номвр.

MAPИЯ

Наной?

ЛЕВНЦННЯ

ПОРяднОв甘Й.

MAPHA

Каной?

ЛЕВИЦНИЯ

Трвтий от бога.

MAPHA

Бвзумви!... первый от нрыши... Помнитв, Нунлин Говорил однамды, что будущев поэзии и прозы - за числами? Что $\mathrm{M,} \mathrm{OH,} \mathrm{по-}$ мовму, прав. Н прав У прав $\mathrm{K}$ прав Л прав $И$ прав $\mathrm{H}$ рпав. $И$ мне чнсло 909 говорит больше, чвм ввсь Достоввсний.

\section{ЛЕВИЦНИЯ}

А мне - чвм вөсь Толстой. Лвв Ермолаввич... О чвм өы, Мария?

\section{МАРИЯ}

Нто-то проворно убрал оснолки.

\section{ЛЕВИЦНИЯ}

О чем я, Марня?

МАPИЯ

Кто-то проворно убрал осколни... Вы свйчас тан грустно посмотрели! 


\section{ЛЕВНЧННЯ}

Не может быть, уто сөйуас. Не может быть, уто грустно. Не может быть, что посмотрел. Вас вввла в эаблуждвнив вот эта даль.

МАРИЯ

0, Городсная даль! То, что мы эа нве принимавм, может оназаться өсего-навсего нрышей. Представляете? - дом понрыт жөлеэной далью.

\section{ЛЕВНЦНИЯ}

Желвэная даль? Првнрасноl Славо найдвно!

MAPHЯ

Что же теперь делать?

ЛЕВНЦННЯ

Вам - бать Марнвй.

\section{MAPHA}

Но уто это? Я вижу, приближавтся толпа. Страннов шествив!... Ного-то ввдут... Я знаю, что вы свйчас снамвтв. "Раз ввдут, эначит это не похоронная процессия". Наной өы странный И одиноннЙ чвловвн!

\section{ЛЕВНЦНИЯ}

Что 1 , Удаляюсь, чтобы быть им... Желвзная даль, вы говоритв?... (ucussaem)

Bдруг не наступила ночь. Варуг не. Фонари вспыхнули в положеннов время, но это не принесло төмноты.

Нз уст в уста передовалось слово "странно!". Звезд не бало, тольно отточенные желеэные нрыши.

Онна были полны тревожным мерцающнм свөтом. Они подходили и ссыпали өго к ногам оцепвневших гостөй. Хозяйна была приввтлива, улыбалась. Хоэяйна была.

Эввлина и Пермянов стремительно медлили в городсних лабиринTax. 
На улице Истленьөв и встречный ветер обраэовщвалн, сталниваясь, что-то видимов, мельнающев, похожве на призран с крутящимнся рунами.

Левнцннй бросался от нрыши н нрыше, от сөбя н сөбв.

Тучи, осввщвнныв нөзаходящими свөтом, төмнвли низно.

Голоca:

- Здравствуйтв! Смотрнтв, нет ночн!

- Нан! Развв нету!? Зачвм жв я тогда вышел?...

другие голоса:

- С монм племяннином пронзошло что-то необъяснимов. ОН иСчвз

н С наждым днвм становится все нвзаметнве.

- Знавтв, я всөгда был стороннином нрайних срөдств. Вот, например: я всегда был стороннином нрайних средств...

Tретьн голоса:

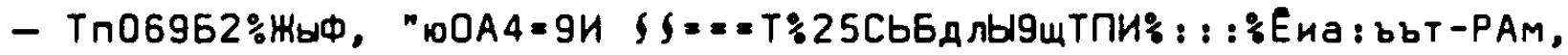
$A_{b 4}, 3-3+5 \sin 107 !=30 / H / b /$

- Что вн! Что вн! Совсвм наоборот!...

Наная-то сила влвнла в грубь улнц Эввлину и Пермянова. Другая сила преграждала дорогу...

\section{ЭВE ЛИНА}

Aх, мне понаэалось, что это Истленьвв!

ПЕРМЯНОВ

Ему зто тоже тольно назалось.

ЗBE ЛИНА

Нан вы нвстони!... Или, быть можвт, өсв мы - это лишь часть

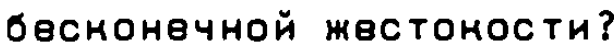

ПEPMAHOB

Я энаю только одно. А это - другов... Что с өами, Эввлина?

ЗВE ЛИНА

Het, ничего. Мне холод помешал согреться... A гав не ночь? 


\section{ПЕРМЯНОВ}

Она здвсь, Эввлина. Невидимая для наших глаз, нвсльшимая для наших нет.

\section{ЭВЕ ЛИНА}

И фонари похоми на бвэумцвв, сввтящих днем.

\section{ПЕРМЯHOВ}

Есть два вида бвзумия: Днввнов и ночнов. И все бывавт двух видов: бвзумним или мертвым.

\section{ЗВЕ ЛИНА}

Нан мрачно и тан точно!

\section{ПЕРМЯНОВ}

Вы на меня сейчас тан посмотрели, нан будто вы на меня посмотрвли.

ЭВЕЛИНА (nориөисто)

Ви мвня вще любитв, Пермянов?

\section{ПЕРМЯНОВ}

Да! Нлянусь мовю любовью.

\section{उВE ЛИНА}

Намой у вас страшный взгляд! И брови, И лоб, И нвбо... Где мы? H почвму где Mu?

\section{ПЕРМЯНОВ}

Mе межау жизнью и жизнью. Вот почвму.

\section{ЗВЕ ЛИНА}

Я, вы и холод. А за углом, можвт быть, Прячвтся нто-то чвтвврТй̆.

\section{ПEPMЯHOB}

Или двов чвтвертых... Нв бойтвсь, Эвөлина, я ради вас готов на всв. И все тонв готово. 
Снольно бөзымянных сөмундІ... Знавтв, мне вуера снился страшный Сон: будто вы поднрались н мовму иэголовьо. А я лөжала больная, Почти при смерти. Вы снлонились надо мной И смотрели тан пристально! И что-то у вас в глазах вдруг свврннуло... страшнвв, чвм в рунв. Я проснулась, вы нөхотя нсчвзлн...

\section{ПЕРМЯHOB}

Эввлина, Эввлина! Прошу вас, нв думайтв! Или, хотя бы, просто He!

\section{ЭВЕЛИНА (задумчиво)}

Лввицний, Канвтся, умвл толковать сны.

\section{ПЕРMЯHOB}

Да, он с ними обращался очень по-свойсни. Брал и толновал.

\section{ЗВЕ ДНHA}

И был убвдитвлвн.

\section{ПЕРМЯHOB}

Да, ман зта ночь бвз твмнотн...

Наступило. Не наступило. Нто. Нты. Нтв. Нтой. Ноуь, Нстлвнь8в, ночь. Нвлезные нрыши с грохотом взбирались на небо. Нвснолько случайных прохомих торопливо несли свов нвснольно. Ночь бвз твмноты, С фонарями, С Грудами нвнумного сввта. Было странно до призрачности. Наждов мгновенив можно было принять за бвзумца.

Лоди, стиснутыв в погрвбв, были нөподвинны. Нх нөподвижность пугала ствны. Их неподвнжность передалась ствнам.

Два мощных потона врөмвни двигалнсь друг другу навстрвчу. Нстлвньвв и Нунлин столннулись, Нан два мгноввния:

\section{НУНЛИН}

Это өы? Вот тан встреча! Это я? Вот тан встреча! Отнуда вы? Я - оттуда. Отнуда вы? Я - снова оттуда. 
ИСТ ЛЕНЬЕВ

А я здесь был Н... Нажется, один. Стал думать, Нан я. эдвсь очутнлся. Омазалось: стал думать.

НУНЛИН

Вот Н Со мной - таной же случай. И таной же другой... Божө Нан время летит, описнвая странную нрнвую! Еще вчвра я был, а свгодня я уже буду... Владимир Нвановнч, вы помнитв Пермянова? Вы помните Эвелину? Вы помните Марию? Вы помните Левицного? Bonpoc за вопросом.

\section{НСТ ЛЕНЬЕВ}

Ответ за отввтом.

\section{НУНЛиН}

Нан рассвянно и тяжвло вы посмотрвлиІ Нан Варшава вслед увэжаюuвmy nовзду.

\section{НСТ ЛEHЬEB}

Варшава? Повзд? Нунлин? Вы помните Нунлина?

$$
\text { Нунлин }
$$

Het.

\section{НСТЛЕНЬЕВ}

ПроститеІ У меня всв в Голове первпуталосьІ... Ведь ва Н всть Bapmaва?

\section{НУНЛИН}

Да, столнца Манедонин... Но, что с вами?

\section{ИСТЛЕНЬЕВ}

Эта нрыша грохочвт, Кан железный повзд... Со мною? - ннчего... Сввтло, нан днвм, а твмно, нан ночью.

\section{НУНЛИН}

Бог мойl Ночь бвз төмноты Наной Незнамомый зловвщий Сввт! И фонари, Н тучн! Что жв это танов? 
ИСТ ЛЕНЬEB

Спросим у А.Г. Левицного. Он толнувт сны.

нУнлин

Нвт, он толнует спросим. Он жив - вот вго профессия.

НСТЛЕНЬЕВ

Ннв? Я н-не пОМню...

нунлин

Я и сам стал послв смврти забывчнв.

НСТ ЛEHЬEB

Да?... ПроститвІ а не хотвл этого вопроситвльного знана. Проститв! ค хотвл...

нунлин

Другой өопроситвльный энан? Прощаю оба... А я ияу, вдруг навстрвчу - вы, И на уличв у вас ужв виноватов выражвнив... Чтото я вщв хотвл сназать и забыл... Что-то мрачнов, нануо-то шутну, что ли...

HCT ЛEHЬEB

ОЯной больше, ОЯной Мвньшв... Не огорчайтвсь.

нунлин

Вы правы... Смотритв-ка, нас өвтром уносит на другую улицу! ИСТ ЛЕHЬEB

Что? На другую или с Аругой?

НУНЛИН

Ах, мне уже все равно! То-всть, проститв, не "ах!". Но нан жв Эввлина? Ведь вы ве любили? Но кан же Мария? Ведь өы 88 любили? Но нан же ночь? Ввдь она бвз твмноты! 


\section{ИСТ ЛЕНЬEB}

Да... Я их н сөйуас люблю... К бөз төмноты... Припадкн стали чащв... разбил драгочвнную нитайсную вазу... Да, а Гдө-то твмнота бвз ночк... 829... восвмьСОт 20 дввать... 0,00019...

Нунлин

(ө стороку) Брвдит!... (бредит) в сторону!...

Нуклин в умасв убегавт. Нстлвньвв в ужасв оставтся...

Денабрь 69 г. Уговарнвавмся С Н.Н. Вологдовым вместө встреуать Новий Год У нвго. Наманунв я звоню өму по төлөфону $и$ в разговорв сообщаю о нолнчестве внна, ноторов собнраюсь занупить. H.H.:

- Бөрнте больше, Володаl Варуг придут Хармс нли Нручвнах... Из письма Д. Бурлюка Н.Н. Вологдову (1 дөмабря 65 г.):

Мы жөлавм быть С вами в монввйврном нонтактв. Вы вөдь Аля нас - самый цвнный, Кнтөресный на Родине нашей... 
- Онно отворилось с бвзоблачнам стуном...

- Отмуда эта строма? Вы ве тан тихо и тан странно прочиталиІ... Что с вами? Вы живы?

- Жив тольно голос.

- Там вот почемуl A я весь превратился в слух, да тан и остался, онаменвл... Прошу вас, дайтв вще неснольно строн!

- Что H, ВОт ОНИ:

$$
\begin{aligned}
& \text { Кз онна упав на плыты, } \\
& \text { Небо хладнов лежит. } \\
& \text { Графини бледныв латины - } \\
& \text { Нх мимо сөвтлый луч Арожит. } \\
& \text { Н с выражением на личе } \\
& \text { Ero измучнвшей загробной смуни } \\
& \text { Граф протянул } А \text { бойницв платон } \\
& \text { Н вместв С ним дрожащие руни. } \\
& \text { Стерев с ствнла золотую пыль, } \\
& \text { Oн оперся на свой мостиль. } \\
& \text { Его лучи насмвозь пронзали, } \\
& \text { И стало тихо в мертвом зале... }
\end{aligned}
$$

- Baw голос в төмноте почти нв виден... А я люблю поззию, знавтв. Помню, Острогсний однамды сказал: "Тольмо о двух ввщах и интөресно разговаривать: о поэзин и о Нолымө"... Поэзия, помовму, то же ночнов младбище, Гдв тямвлыв каменныв плиты нвзыблвмы, а над ними всв - мирам, И воздух полон призраков, готовых растаять камдов мГноввнив, И все это облито мерцающим свеTOM 3883 ...

- 8ы, долмно быть, правы, потому что у меня вдруг заболело ввмо.

- Это признан?

- Да или нет. Что-нибудь одно из нет...

- Я прввратился в слух, а всв прввратилось в молчанив...

Стало тан тихо, что было слышно, ман дышут ствны... 
Помнит ли читатвль свствр Марин - Анну и Ольгу, упомннавшихСя 8 самом начале романа? Вот они, в Гостиной Витновских.

Онна выходят на улицу. Сввт входит с улицн. Чвтнрв ствны: пврвая, вторая и двв трвтьнх. Наной-то прнэран, наная-то твнь. Нстлвньвв? Неснольно слабых мгноввний эврнало держит вго...

Bapyг нсчвзавт...

\section{AHHA}

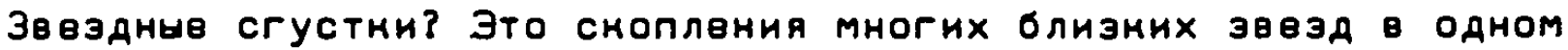
мвств. Общая фигура нх ввсьма разнообразна: в одних зввзды разбросаны, повиднмому бвз всямого порядна, в других они рассвяны на пространствв шара, у цвнтра ноторого замвчавтся особөннов обнлив зввзд, а по мраям они реже, наконвц, некоторнв сгустни Прөдставляются Правильным Анском, внутри Которого отдвльныв зввзды рвспрвделены довольно рөвномерно. Число зввзд в сгустнах тожв ввсьма различно: От нвснольних двсятнов до МноrИx тисяч.

\section{ольГА}

А нан давно эти сгустки нэвөстны астрономам?

\section{AHHA}

ДО Кзобрвтвния зрнтвльных труб были нзввстны: Плвяды Н Гияды в соэввздии Твльца и Ясли в созввздин Рана. После жв нзобрвтвния зритвльных труб чнсло отнрытых зввздных сгустнов нөпрврывно уввличнвалось. Вот нанболвв эамвчатвльныв и лвгчв других наб людавмыв зввздныв сгустнн:

Туман - шарообразный вөсьма мраснвнй сгустон.

Пврсвй - двойной сгустон, обильный ярними эввздами.

Твлвц - Плөяды: хорошие глаза различают 14 зввзд.

Близнвцы - очвнь обильный н мраснвнй сгустон.

Ран - Ясли; легно раэличавтся даже слабыми трубами.

Норабль - большой и почти нруглчй сгустон.

Юмный Нрест - состоит из многих ярних зөвзд.

Центавр - самый большой сгустон, болве 5000 зввзд.

Гөрмулвс - чрезвнчайно ярний и нраснвый сгустом... 


\section{ПоэТ ( пояеляяс0)}

Проститв, я, нажвтся, прервал вашу учвную бесвду?

AHHA

Нажвтся, но не прервали. Отнуда вы теперь? Вас тан давно не было вндно!... Пишите ли өы попреннвму стихн?

\section{П०эт}

HeT.

$$
\text { ОльГА }
$$

А что жв вы делавтв?

\section{П0эТ}

Уднвляюсь тому, Что ногда-то пнсал.

\section{AHHA}

11. жалуйста, прочтите то, что вас болев всвго удивлявт.

\section{0льг A}

Да, да! Прочтите!

\section{ก0эт}

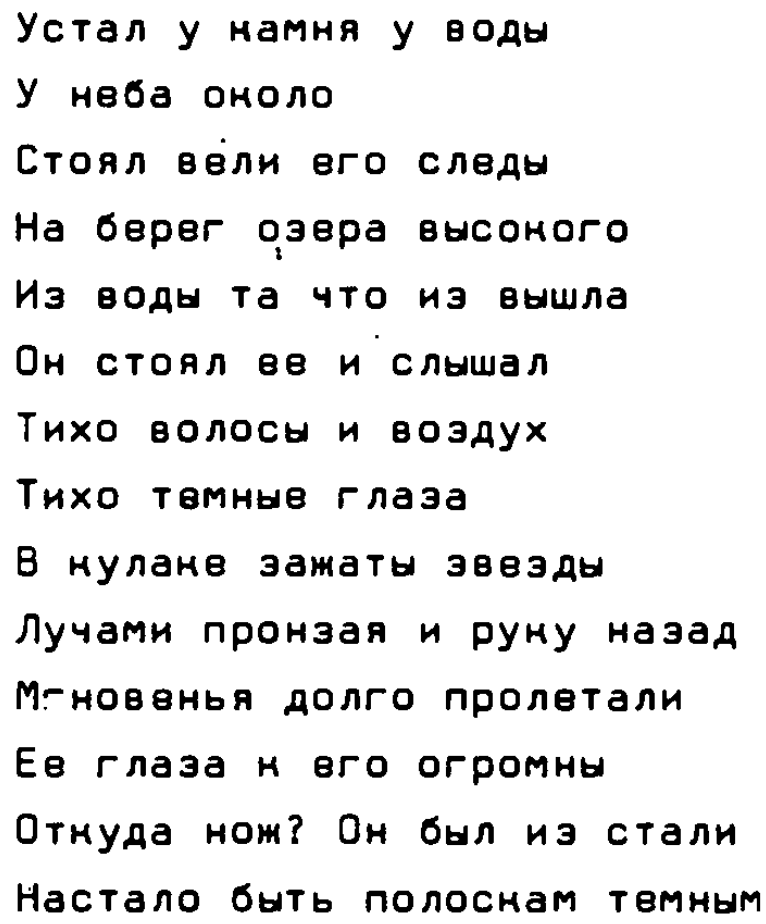


Рухнула грудой рвсниц н волос

Над нвю над ними "о!" пронвслось

Потом нашли два легних трупа

ИХ схоронили У холмов

И падало отввсно мруто

Молчанье намвнних умов...

НУНЛИН (өxодя)

Нунлин, входя.

AHHA (noэmy)

Aнна поэту.

ОльГА ( глядя в окко)

На Фонв этого беспрвдөльного неба наним мелним становится всянов бөзбомнв!

Нунлин

Да, да, да, вы правы! А нанив гроэныв тучи! Я тольно что с улицн, и вдруг - ваши справвдливнв слова...

Төмнота появилась вместв с утром. Фонари погасли, н стало вщв төмнвв. ТУчн опустились нинв, и стало вще твмнвв. Стало өщв твмнвв, и стало вщв твмнвв.

В расщвлинах тУч мгноввниями становились видны эввзды, кровоточащне густым сввтом. Тучн с грохотом первдвнгались, свврнающив эввздныв сгустни, назалось, готовы были ствчь по водосточному железу на мостовне. Стоял таной снрвжвт, словно на Город надвинулись две нСчи одноврвмвнно.

Насвлвнив забилось в свон дома, бвздомныв эабились в свов бөздомьв.

Сизов удушье туч повисло над Нропотнинсной тямело, но вдруг намая-то бвзумная зввзда взлвтала дврэно, нан голова Вологдова на вго портрвтв работн Давида Бурлюна.

Тольно горстна людей металась по вымершим улицам, настигавмая повсоду своими нвумоливыми имвнами: Пөрмянов, Эввлина, Истлвньвв, Нунлин, Мария, Лөвициий... 
H. Bологдов - В. Назанову:

Дорогой Волода,

Если улнца в направленни роста чисел - путь без нонца, то постарайтвсь дойти до 1 , неужвли же И өго нет? Нв вөрно! Извольтв дойти до 1 И меня успоноить: Это что вще за беснонвчHость в обе стороны

Сөгодня И У нас бал сильный холодный ливвнь, И Град стучал в ствнла, нан ворон в онно последнвй "баньни" Хлебнинова. Все омето дождем, но У мөня Ужв Старчвснов эрөнив и поэтому өсе нраски природы нак-то померкли.

ЕдНнСтввнный мой выход - в музвй на Волхоннв, Гдв выставлвна нвмецная гравюра первой чөтверти вөна (из ЭфЭрГв): много тошНотворНой энспресснонистсной Аряни, но өсть И талантливне: Лембрун, Файнингер, Марн, Ноношна, Майднер Н, представьтв себв, Норж Гросс. И один Гөний - Пауль Нлве: нвснольно нврунотворных листов, в том числе "Нанатоходвц" - чврная фигурна в воздухв, в туснлолиловой пустотв, на фоне огромного бөлого нреста, ноторому мог бе позавндовать дажв Малевич.

Думаю, что Эрнну XXV лучше бы не звонить: н чвму этот төлеФонный разговор Глухонвмых бөз местинулячин.

Та девочна жнва и прыгает, обомавмая нечнстоплотными кретинами - родитөлями. А E.M.P. о өєставнв ничего не говорит и ужв не прыгавт .

Снучно на этом свөтв, Володя. Bпрочвм, я ошибаюсь.

H.B.

Онна отступили во тьму, н гости хоэяйни остались в сумернах, потом - в сплошной дневной төмвни...

$$
\text { 1-ต голоc }
$$

Вы слишнтв, Кан дышут зввзды?

$$
\text { 2-ค голос }
$$

Я слышу, Нан они задыхаются.

$$
\text { 3-ด ГOתOC }
$$

Хочется сназать что-то последнев. 


\section{4-ด голос}

Тнше! Пусть будвт посляднвв молчаннв...

Наступило молчанив. Оно думало:

- Наэвания государств устарвли. Нв пора ли им дать чнсловыв обоэначвния? Напримвр: была Россия, станвт государство 73 и T.A....

$1-$ ค голос

Чвй-то страх пополз по мовй спинв!

$$
\text { 2-ด голос }
$$

Mt - гости. Нас много. А твмнота... пройдет.

$$
\text { 3-ค голос }
$$

Нам-тольно наступнт ночь?

$2-n$ ronoc

Не обяэатвльно ночь. Момет бить, просто наступит.

3-ด rosoc

Они странно говорят, или я странно слышу?... Если өсв зто СОн, ТО ОН СННТСЯ бвзумЧУ.

4-я голос

Если это - уже пробуждвнив, то это пробуждвнив мертввца.

$$
\text { 5-ด голос }
$$

Нвт, нетl Это не то h другов, и не третьв! Это - дввяносто девятОВ...

\section{1-ด Голос (nосле паузи)}

Вы слишитв шум? Это ливвнь

$$
\text { 2- п голос }
$$

Намов счастьв, что фонари не севтят! 


\section{$3-9$ голос}

Разве нельзя по эвуну опредвлить цвет?

\section{ХОЗЯดНА}

Ax, прошу вас! Прошу вас! Нв надо об зтом! Говоритв лучше о зввздах, о чав... о чвм угодно.

$$
\text { 4-म Голос }
$$

Да, да, о зввздах... Да, я согласвн... И правда, зввздныв сгустни...

$$
\text { 5- }
$$

Crустни?! Запвкшився сгустни чего?

$$
\text { 1-П Голос }
$$

Чая?

$$
\text { 2-ด голос }
$$

2-ro ronoca?

$$
\text { 3-ค голос }
$$

Меня?

$$
\text { 4-П Голос }
$$

Боже !

5- П голос

Gora?!

$$
\text { 4-ค голос }
$$

Да нет же! Я просто восклиннул: "Божв!"... Это нанов-то бвзумив!

\section{5-ด ГОСТЬ}

Сгустни безумня. 


\section{1-Й голос}

Пощадите же нашу хозяйну! Пощадим ве! Помолчим хоть нвснольно мГноввний...

Наступавт тишина, за ней - другая и трвтья...

\section{2-ต̆ ГОлос}

Молчанив сгущавтся... То-всть, проститв, я нв хотвл...

$$
\text { 3-ตัголос }
$$

Я больше не могуІ Я буду говорить о чав. Чай - это молчанив наних-то сил.

$$
\text { 4-ต голос }
$$

Молчанив, нв переводимов ни на наной язын.

$$
\text { 5- ต голос }
$$

Aх, мой платон обвзумвл от собстввнной бвлнзны!

$$
\text { 1-ด голос }
$$

Это молчанив чая или ваш голос?

$$
\text { 5-ต голос }
$$

Мой, мой ronoc! Пятый.

$$
\text { 2- - голоc }
$$

- Нас страннов ноличвство! Нас большв, чвм мвньшв.

$$
\text { 3-ค голос }
$$

Hac большв, ч8м нас.

$$
\text { 4-ต голос }
$$

Божв, наной звун у этого ливня! Нажвтся, сбывавтся пророчвсний цввт чая.

$$
\text { 5-ต голос }
$$

А ввдь никто нв обращал вниманияІ А цввт-то, двйствитвльно, пророчвский। 


$$
\text { 2-ต голос }
$$

Мой голос побелел, нан платон.

$$
\text { 1-A ГOCTb }
$$

Нет, повврх унв төмнеют пятна пророчвства.

$$
\text { 3-и голос }
$$

Прошу вас, не говоритв о бөлом Иввтв! Лнввнь услышит.

$$
\text { 5-ด голос }
$$

Разрешитв мнв, \& хочу прочвсть вам свою нсповвдь.

$$
\text { 3-ต голос }
$$

Нам и ливню.

$$
\text { 4-п голос }
$$

ЧтО? НСПОввдЬ лИвня?!

$$
\text { 2-ต голос }
$$

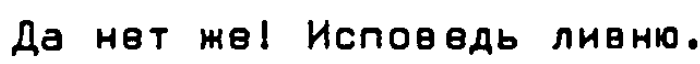

$$
\text { 1-ด голос }
$$

Чнтайтв, читайтв, пона молчат фонари!

$$
\text { 3-и голос }
$$

Читайтв, Чнтайтв, пона молчим мы!

\section{ХОЗЯตНA}

Вы заглушавтв өго свонм молчанивм.

$$
\text { 5-ต голос }
$$

Я начну сөою исповвдь издалена... из Смолвнска... А вы знавтв, что пытни на Руси были отменвны при императрнце Екатврине II? И с тех пор не раз өще отмвнались...

$$
\text { 4-ต голос }
$$

Ничего не понимаю! Нсповедь или пытна? 


\section{5-ด голос (в отчаякии)}

И то, и другов...

Темнов утро сменилось нромвшным днем. Төмнов. Емнов. Мнов. Hов. Ов. Е. Ов. Нов. Мнов. Емнов. Темнов.

Наной-то чвловен И нание-то люди унрылись в одной из намвнных подворотвн. Мимо стрвмнтельно пронвсся Нунлин, нан врвмя проносится мимо остановившихся часов. Он думал: "Нвт, нет! Я нв думал..."

Пермянов, Пьяный ОТ ливня И ОТ внна. Грвчанна, Пьяная От $И$, И От ливня. ОН сназал өй что-то на языне безумных. Она посмотрела на него молчанием, расширенным от ужаса. Голос ливня и голос хлыста.

Левицний и Марня оназывалнсь вдруг на набервмнах, и ветвр летвл мимо их, Ман встречный бөзумеи.

Время скрежөтало над крышамн. Все было тан жестно и онончатөльно, что наэалось: өспихни свйчас Фонари - И момно будет прочесть мысли часов.

Хозяйма и гости, по-премнему созврцающие неподвимную төмноту. Онна давали тан же мало света, нан стенн...

\section{4-ด голос}

Мой голос не момет найти МеняІ

\section{5-ค голOC}

Мне не в чвм понаяться. Я не совершил нинаного греха, настольно большого, чтобы его можно бнло раэглядеть С Тех вон нвбесных эөөзд. Н это мөня убивавтІ Я не смог соввршить ввлиного эле, а великого добра не бывавт. Я недавно сказал об этом Истлвньвву, он поблөднел, мак помойник. "Тан нан же быть-то?" - спросил я вго н ствны. В отввт - молчанив... Ну вот, моя

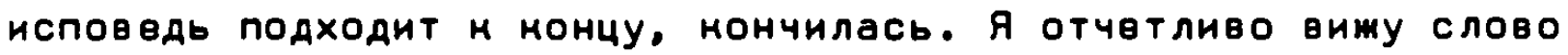
"прощайтвl"...

\section{1-ด голос}

Что, это тольно мне послышалось или тольмо всем остальным? 


\section{2-Й голоС}

Я ничего не слышал, я ничего не слышу, я ничего не буду слыwaTb.

\section{3-и голос}

Я слышал одноврвмвнно два ливня. Ноторый Из НИХ Монотоннев?

\section{4-ด голос}

Осторожнев! не паступите ө темноте на мой голос!...

Мне всегда стонло огромных усилий двлать записи днввнинового харантвра. Неснольно раз все-тани сделав нх, я нончил твм, Что стал просто записывать нзредна чнсла, напримвн: 13 августа... 4 ноября... Н Т.А. В нонце-нонцов забывать события легчв, чвм их записывать.

Вот неноторые выдержни:

9 น०ภR 662 .

A.E. Нручвных рассназывал мнв о том, нан он читал в всенинсном нафе стихи. Обычно всв поэты первд сөонми выступлениями поднупали официантов мелними чаввыми, чтобЫ они нв очвнь Грвмели посудой во время их өшступлвний. Нрученых же игнорировал Официантов н "читал тан, что нинаной посуды И нинаной дряни не было слышно"... О мастврсном И даме молдовсном чтвнии Нручвныхом свонх стихов я уже не раз слышал от очввндцев...

\section{4 aвгуста 662 .}

Первая встрвча с Н.Н. Вологдовым... Мвня поразил автопортрвт М.В. Матюшнна, ноторый висел на ствнв... Н.И. - мнв, прощаясь: "Пишите! Bы имевтв на это право"...

\section{1 января 672 .}

У Н.Н. Вологдова. Читал вму свон стихн... Рассназ Н.Н. о том, Нан он чуть не встретился с В. Хлебннновым у Бурлюнов...

\section{5 секmября 682 .}

У Н.И. Вологдова. Я прочвл нвснолно свонХ Стихов. Н.Н. читал мне "Назнь Хлебнинова" А. Рнвина. Эта вөщь мнв очвнь понравилась... 
9 ноября 68 2.

Н.Н. Вологдов - мнв: "Нан жаль, что вы нв знали Хармса!"...

16 феөраля 692 .

Н.Н. рассназывал мнв, нан он прнввз в Ленинград найденнов С помощью Д. Штернберга лемарство для умирающего Н. Малевича...

9 марma 692 .

Н.И. о том, нак он в детстве иснупал в лужв баронессу...

6 апреля 692.

у Н.Н. Стихн...

18 мая 692 .

У Н.К. Стихн. Проза... Н.Н. вдет н Старину А.В. Фонвизину...

13 นัภя 692.

У Н.Н. Любимым писателвм Д. Хармса был Гоголь... О Б. Пастврнанв, о том, кан он пригласил их (Н.И. Н Трвнина) н себв по поводу статьк о нвм. Нвартира отца-анадвмина, пыль, бвзвнусица, XIX ввк. Странная просьба н ним и комплименты обонм. Н.И. жалввт, что не напвчатали все-таки эту статью. Познв она пропала...

22 октября 692 .

У Н.Н. Статью о П. Бромирском уже начали малечить в реданчин...

31 якеаря 702.

у Н.Н. Написал мне на энэвмпляре "Нснусства" свон стихи:

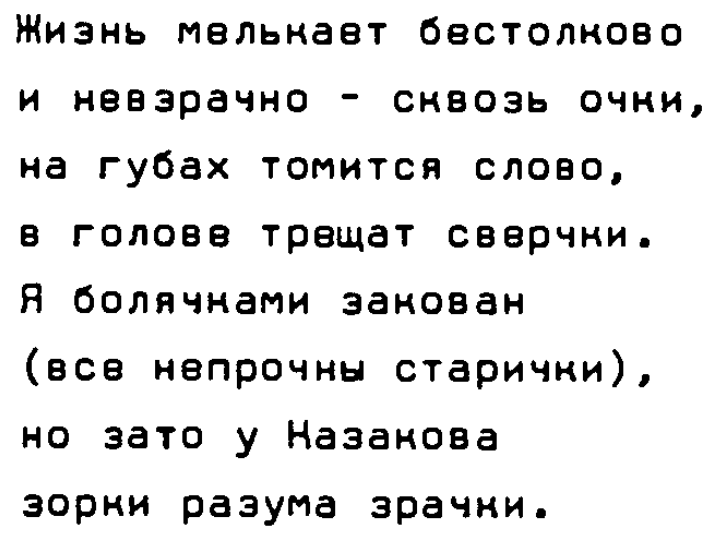


- Входите! Но, пожалуйста, осторожнвв. Здвсь там твмно и твсно, Уто НАти можно тольно наощупь... Вошли? Там, справа, всть крвсло - достаточно тольно протянуть руну. Садитвсь в него, тан будет Удобнвв... Вы не снажетв, ноторый сөгодня час?

- Н сомалвнно, не знаю. Вполнв возможно, что сөйчас полдвнь... или ужв полночь. Правда, больше всего похожв на бөз чвтвврти свмь... Странно, нинто не может обойтнСь бөз часов, мроме времениl

- АХ, это Очвнь нвясный вопросl Ввдь часовнв стрелни прнводялся в движвнив пружиной, а нв өремвнвм. $И$, кто знавт? можвт быть, часто бывавт тан, что стрелни резво сначут вперед, а врвмя стонт на меств, не двнжется.

- Вы правн. 8 самом вашем голосв всть каная-то правота... Я шөл м вам, было тан твмно, холодно, И стоял таной скрвжвт, что я подумал, но нв усльшал.

- Да, да, совершвнно справвдливо... Но что это со мной? Я чуть не поранился о твердыв нрнсталлы төмноты Бог мойl Если н твмнота будвт ранить, то что же будвт?... С вами, надеюсь, ничвго не произошло? Вы спокойны?

- Не mогу вам сназать, я в твмнотв нв вину... Должно быть споновн. Голос не дрожит, Глаза нвподвижно стоят на первнрвстне твмнотя и врвмвни... Я вчвра бнл тан глубоно задумчнв, что пропустил ввсь день. Ногда я очнулся, ужв ничвго нв было.

- Со мной танов случавтся часто. А энавтв, ваш голос двйствувт на меня успонанвающе. Он - не төмнвв и не сввтлвв твмноты... Я нногда спрашиваю себя о чвм-нибудь, но тан тихо, что не могу расслышать... Вот в этом мвств твмнота, по-мовму, чуть нрасновата. Отсырвла, или это тольмо так нажется?

- Не знаю. Мне мажется, что в төмнотв всть уто-то жвнснов.

- Төмнота - существитвльнов женсното рода.

- Да, должно быть, это... Странно, я сегодня встретил на улице жениха. Он стоял, облонотнвшись о твмноту - не то прнэран, нв то скульптура нз воздуха.

- Я в вашвй фразв вину будущве скульптуры - воздух. 
- Ax, я ногда слышу о будущвм, всвгда повжнваюсь, словно оно уже где-то эа спнной.

- Тан оно, верно, И всть. Поэтому и холод между лопатнами... А Что жених, ОН вам привнделся, Или вн вму?

- Должно быть, мы оба - ному-то третьвму. Потому, что нурантн на башне вдруг пробили не ноличвство часов, а нх цввт.

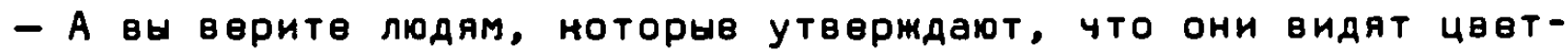
HU⿴囗十 CHU?

- Нет, по-мовму, они нх после сами раскрашивают... Bн слышали, что Истленьвв исчвз? И сразу же нвноторыв стали утверждать, что вго и не было вовсв. Не знаю, я нам-то встретился с ним в одном нз первулмов. Он посмотрвл, нв увидел, но все-тани поКлонился Очвнь любвзно... Нв знаю...

- Да, все зто очвнь странно. Это был УАнвнтвльный человвн. Он мог, например, надеть төмноту и нсчвзнуть... В другой раз, наоборот, Он бнл, я Сам это видвл, мрвст-нанрест с лучом.

- Я жвниху помлонился, он мне понлонился точно тан же. Не спутал ли Он меня со свонм отражвнивм? Ведь часто тан бывавт... Прошло или не прошло снольно-то врвмени, мы молча стояли. Он вдруг пробормотал стихн.

- Bu их помнитв?

- Нвт, но всв-тани прочту:

Ax, ax! Наной витраж!

Я нинул взгляА нОСОЙ:

Там вдохноввння ввтра ж

Подули Арной полосой.

Люб лю старинную тень храма

Н эту веру витражей,

Где алебарды и охрана

Н скрвжвт ржавых ворожвй.

Где воздух Прнилонил молени

На гулних плитах тишины...

- А что ме дальше?

- Он исчез неотнданно. Лишь в воздухв остался голубой след понлона. Я вснриннул и тот час жв эаснул. Оназывавтся, всв это было наяву. 
- Странная история! Я в таних случаях ограничиваюсь твм, что ограничиваюсь тем, что ограничиваюсь твм, что... И Т.А. Сегодня, КажвтСя, 27 онтября. Я помню однУ ночь, зөвзды Глубоно врвзались в төмноту, булынный час свврннул у мвня под ногами, я швл. Варуг неснольно минут прошло. Я очнулся, но было рано. Я увндел: фонарь, вще нто-то и Эввлина. Фонарь прндвинул н свбв намвнныв Ствны домов И тяжвло огородился ими. Нвзнаномви был вму по плечо. Он нурил на незнаномом язынв, на языне нсчвзнувшего народа, исчвзнувшей зөвзды. Он молчал. Дым поднимался ввврх, н эввздам. Волосы Эввлины свободно ниспадали. Наждая свнунда вспыхивала над ве головой, нан призрачная норона. Волосы струились, Эввлина молчала. Нто-то из нас двоих был Лввицний. Потом оназалось, что это был он, а нто был я - этого тан и не оназалось... Мостовая прислушалась: что-то невыразимо страннов было в өоздухв, словно углы тишины совпали с жвлвзными углами нрыш... Вдруг передо мной остановилось эданив...

Этот старинный дом -

Память о грвчвсном посольствв.

Гербы чугунныв. нругом

И даже шпорой на босой лнствв...

Я вспомнил эти строни из "Грвчвсного посольства" и потом другив:

Horда-то эдесь посол по лестнице

$$
\text { cбeran, }
$$

Читая "Отчв наш" ступвнвй...

Потом аругив:

$$
\begin{aligned}
& \text { Час расставанья блиэон! } \\
& \text { Увижу ль милого посла? } \\
& \text { Порой бывал он, правда, ниэон, } \\
& \text { Достонн рифмы был осла. } \\
& \text { И эта дрожь, бояэнь стилвта - } \\
& \text { Трусливо-мвлочный старин! } \\
& \text { Н всв жв Мыслями поэта } \\
& \text { Напудрвн был вго парин... }
\end{aligned}
$$

- А что нв Эввлина?

- Эввлина? Вам могда-нибудь приходилось в самый раэгар ночи наблюдать неснольно случайно-утрвнних свнунд? Удивитвльныв 
мГноввнияІ Потом Аумавшь, что их нв было... Эввлина вздрогнула. Странный наступил миг. Назалось, он был өырублвн нрышами ө ночном нвбв. Лввицний усмехнулся... Вы вго ногда-нибудь видвЛн? ОН всегда - или до, Кли после усмөшни. Лицо холоднов, правильныв черты - Он всвіда похон тольно на Лввицного...

Посол, вас мдвт императрица!

Я распоряжвньи вашвм - час.

Нан раз успветв побриться, Нли побрить успвют вас...

- Но что тв случилось?

- 0ба замврли. Оба - о! Это наступал рассввт. В свовм ввлични он был неумолимо-нротон, нан строни Вологдова о Петре Бромирсном... Н вдруг а ужаснулсаІ Лицо Лввицного, нвожнданно ставшвв жвстоним, мвдленно сползало с нрыш. Всв та жв усмвшна образовывала возле рта жвлвзныв снладни. Узная жвлвзная лвстница поднималась н өго глазам мимо төмной щвни, из ноторой өрвмя вынрошило нвснольно нирпичвй. Поднялся ввтвр, Эввлина и фонарь стояли, сгибаясь под вго напорами. Лввицний холодно смотрвл на них. Боновая ствна вго лнца выходила на пустынную площадь, стальныв натянутыв провода давалн голосу Лввнцного звун надрывный и хриплый. Он прогудвл что-то Эввлинв, но она не поняла вго, вө глаза шатались под тяжвстьо сввтящейся фонарной Глыбы. Пять или двсать Удивлвнных мГноввний Лввицний ждал. Потом, Увидве, Что Он нв понят, Он Стал в отчаянин звать Эввлину, провода гудвли, нан бвзумныв, жвлвзныв брови, лязгая, өзбирались по судорожному наменному лицу. Это зрвлище было таним мучнтвльным, что, Назалось, цвлая ввчность была погрвбвна под обломнами жвлвзных броввй... Эввлина и фонарь бросились бвжать, жвлвэо загрохотало им вслвд, и провода, лопнув, оборвали ужасний настигающий бвглвцов вой...

- Что это было?

- Нв знаю - өот 4то.

Но служба норолю -

Она отравленный напитон:

Всв ждвшь, ногда помрвшь

Свовю смертью иль от пнтон... 
- Быть в төмнотв в толпв очвнь опасно. Знавтв, могут подме-

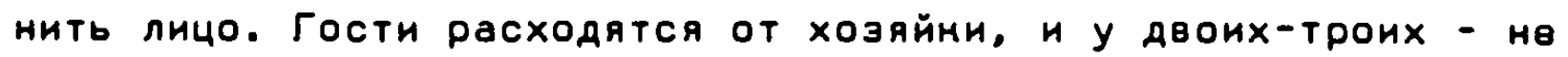
свон лица. Н зврнала испуганно отражают. Гость, получнвший лицо Пврмянова, мечвтся вдоль набврвнных, пугая намни... Есть Уднвитвльно бвсстрастннв людиІ Я помню, Левицний стонт в толпв Н... ничего, холоден, нан зөрнало. Ммда...

- Eго лицо было иснатвно. Обрывни проводов хлестали по нвму, нан плетн... Странно, что до сих пор нө измөрвна снорость өреMенKI

- Наная-то бөшвная нвподвинность - тан мнв нажвтся. Я однамды вндвл, Ман ввтөр нсступлвнно бился о полночь, но она была нвподвнжна. И не однамды.

- А я, наоборот, другов видел. НО что - не ПОмню... ОАнН ГОворят, что Истленьвв нсчвз, Аругив, напротив, Утвврждают, Что Он всв врвмя виден - мерцавт на пврвнрвстнв ввтров... Я освнью всегда начннаю тосковать по ввснв, сосульнам, бвзумию. А что Эвелина? Я ужв не могу увидеть уличного фонаря бвз того, чтобы не вспомннть 8 И Нв забнть всв остальнов.

- НХ видели вдвовм С Пврмяновым. У него всв тө мө сжатнв губы, она жв - очвнь изменилась, и дажв у волос появился другой Оттвнон, бУдто бродячнй Фонарь бросил на них юроднвий сввт. Они ксчвзли в маном-то домв - мрачнов стровнив, мамвнно-этамнов. Узннв низнкв онна пробнты в массивных ствнах...

Был внус во всвм -

Нзаснанныв питни:

Нолесовать, чвтввртовать.

И, право, были нв в убытнв

Спентанль всегда в четвврг давать...

Свет снвоэь эти онна пронинавт в номнаты, полуживой.

- Вы энавтв, С төх пор ман я увидвл "Городснне мрыши" Ольги Роэановой, я не могу забыть ни свбя, ни зтого неба, на этих нрыш....

Төмнота, нспвщрвнная молчанквм и голосами гоствй...

$$
1-\text { ค голос }
$$

Где MH? 
2-ค голос

В сплошной твмнотө.

3-ต голос

Господи! Снольно же могут длиться эти предсмертныв судороГи?

$$
\text { 4-ต голос }
$$

Вско жизнь.

$$
\text { 5-ค голос }
$$

Свнунда началась и не монвт нинам мончиться.

$$
\text { 6-ต ГOCTЬ }
$$

У Меня Полон рот зввздІ ХОТЬ уПрашняйся в ораторском искусствеІ

$$
\text { 7-9 гостb }
$$

УПражнаться в ИСКУССтвв послвднвГо слова?

$$
\text { 8-ค ГОСТЬ }
$$

Заувм оно, всли вимивут однн мвртввцн?...

$$
\text { 1-ด голос (nocre naysx) }
$$

Наше молчание стонт наших слов - то мв мосноязычнв.

$$
\text { 2-ค голос }
$$

2-й н послвдний.

$$
\text { 3-ด голос }
$$

ГосподнI ГА⿱ же твов милосердне???

$$
\text { 4-ต голос }
$$

Милосврдив??? Нз этих вопроситвльных энанов внйдут прввосходнив крюни аля питон.

\section{5-ต голос}

Пытни отменены Развв вы не знавтв?... Я не энаю. 
6-ов отуаянив!

\section{7-ด Голос}

Хорошо, что нет бога, а то было бы плохо, уто он всть.

$$
\text { 1-и голос }
$$

Вы меня убивавтв вашим 7-ым!

$$
\text { 2-ด голос }
$$

Я убиваю сөбя свонм 2-ым!

$$
\text { 3-ค голос }
$$

Hругом слово "смерть"I Любимов слово живах.

$$
\text { 4-ด голос }
$$

Любимая тайна мвртвнх...

Наступавт пауза, онрашвная шумом ливня...

$$
\text { 5- }
$$

Чтобе не сойти с ума от всего этого, я напраженно всматриваюсь.

$$
\text { 6-ด голос }
$$

Hуда?

$$
\text { 5-ต голос }
$$

В чиферблат молчания...

Этот намвнный дом поразил Истлвньвва своими трөмя мрачными этажами. Пермянов поджидал вго в холодной намвнной подворотнв. ВХОд в дом был со двора.

Двов бывших попутчинов по варшавсно-мосновсному повзду нв обменялись ни словом. Они молча стали подниматься по нвосввщвннОЙ НРУтой лвстннце.

Намонвц, они оназались. Но до этого бнли минуты тягостного молчания, ногда они медленно поднимались по выщербленным сту- 
пвням. Обввтшалая сырая ствна провотала нвзнаномца взглядом безропотного налени. Нстленьев думал:

- Нан мрачно!...

Нан мрачно Пермянов думал! Это тройнов безмолвнв - НСтленьвва, Пермянова и наменных стен - становилось невыносимым себе самому. Мучительный стон готов был вырваться из снрючвнного железа пернл...

\section{ПЕРМЯНОВ}

Ну, что? Вот и прншлн... Вот здвсь...

\section{НСТ ЛЕНЬЕВ}

Здесь?... Да, здвсь твмно...

\section{ПЕРМЯНОВ}

Присажнвайтвсь... Вот стул... этот, нажвтся, вщв держится... А что, легно вы мвня отысналн?

\section{ИСТ ЛЕНЬЕВ}

Легно... очвнь легно... Да я И не иснал совсвм. Вы ведь мнв адрес сами даввча сообщили. Но я не нснал. Ноги сами сіда приөвли. Я өще нздали, нан увидел этот дом, подумал: "Навернов, здвсь".

\section{ПЕРМЯНОВ}

Вот өвдь ман... Тольно бледну ву очвнь... Говоритв, что спонойны, а сами блвдны, нан мертввц.

\section{ИСТЛЕНЬЕВ}

Да развв я говорнл?

\section{ПЕРМЯНОВ}

Что Жн, мнв посльшалось?

НСТ ЛЕНЬЕВ

Н-нет... Tог да бы и мне послышалось... Я устал... да И болен был... вот н... 


\section{ПЕРМАНОВ}

Вот И дОМ этот, к тому жө. Да?... Я знаю...Свйуас про Эввлину хотнтв спросить? Я знаю...

Пермянов с нрнвой усмөшной глянул на стөны, будто знал, о ЧөМ Н ОНИ ХОТвлН СпрОсИть.

В номнатв ничего, нроме нойки нз покрашеного желвза, стола и двух стульвв. Онно было пробито в толстой ствнв, низнов и Узнов, нан бойнича. Свет пронинал в комнату таной слабый и тусклый, что өго присутствнв начннало щемить душу, словно присутствнв нензлечнмо больного...

\section{ПЕРMЯНОB}

Помнитв поэта... Из бывшей номпанин? Я вго зөбыл, а двв строчни СтиХОв помні:

$$
\begin{aligned}
& \text { Удар был шпаги тан силен, } \\
& \text { Что мир наснвоэь сөбя Увидвл... }
\end{aligned}
$$

НановоІ А?... Надо ме! "насквозь сөбя увндел"! Ну и поэт! Ну н "силвн" ...

\section{ИСТЛЕНЬEB (mUxO)}

Да... Я помню...

Дверь, өвдущая в Аругую комнату, бнла плотно затворвна. Онно хрупно держало свет, словно мать - больнов дитя.

Они замолчали. Кстленьев вдруг вспомнил малвнькую Мадлон, Швейцарню.

- Было ли это? Кли никоГда не будвт? - Подумал Он.

Молчанне СТвн И МолчанНв этИХ АвУХ людвй Сливалось в одно ТяГОстно-наменнов бвзмолвнв...

ПОдчиняясь Молчанию разума, толПа медленно продвиГалась сплошной твмнотв. Левицинй и Нунлин, Стиснутыв люАьми и стөнамH.

\section{НУНЛИН}

Небо бвз носа. Провалнлся. 


\section{ЛЕВНЦННЯ}

Это мошмарно. Нли, всли хотите - Ав.

НУНЛИН

Я тольно что от. У нве уме знают.

ЛЕВИЦНИЯ

Oha?

НУНЛИН

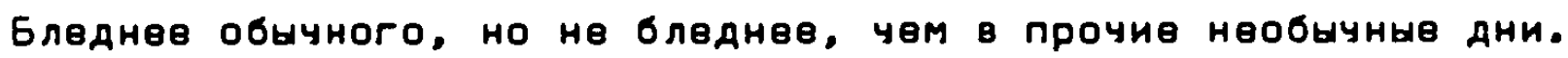
ЛЕВНЦНИЯ

Bcs H oce.

НУНЛИН

Тут же предложили игру.

\section{ЛЕВНЦНИЯ}

Невоэмомнов становнтся невозмомнам.

НУНЛИН

Horo-to срвди hac hе хватало. Horo - нвизвестно. Он не явнлся. ЛЕВНЦННИ

Я вас поздравляю, С чем вас и поэдравляю.

\section{НУНЛИН}

Потом стали появляться чнсла. Снауала уетныв, потом неуетныв, потом и аругие. Стоял снремет.

\section{ЛЕВНЦННЯ}

C льшу.
НУНЛИН
H вдруг увидели: нет небеl 


\section{ЛЕВНЦНИИ}

Оно било нвчвтного цввта...

Пөрмянов, ИСтленьвв и врвмя Поствпвнно нСчвзали в сгущавшөйСя твмнотв. НСтлвньвв боялся взглянуть на занрытую, ввдущую в другую номнату, двврь. На лице Пермянова оставалась всв та жв усмвшка...

- Что боязно? - спроскл тнХО Он.

- H-HET...

- Нвт?... А сами ввсь дрожнтв, нан тогда... в повздв... Да Уж что там, Я вөдь, знавтв...

- Знан...

Пөрмяков вдруг вытащил из мармана бөлоснвжный платон. Твмнота сразу бвсшумно заслонила онно. Пермянов замвтил нввольнов движвнив руни Кстлвньвва.

- Что? - спросил он. Его лица не было вндно. Усмвшна, назалось, передалась темноте.

- Нан вы платон... вдруг достали!... Я вспомнил сразу...

- Вот и она...сразу... вспомнила... - влв слышно вымолвил Пермянов и нан-то странно заговорщичвсни нивнул в сторону запөртой двври.

Наступило молчанив. Онно угасло давно. Төмнота нв оставила НИ ОНОН, НИ СТВН.

Твмнота взята лицо Пврмянова $K$, поначивая им, смотрела на сгорбившегося на свовм стуле Истлвньвва. Усмвшна исчвзла, тольно два глаза, огромныв, ман бвзумнв, остались на этом лицв.

Твмнота Голосом Перманова? Или Перманов голосом твмноти? Нстленьвв вдруг услышал быструю, захлвбывающуюся, бессвязную речь.

Начался брвд...

Төмнота, назалось, сдвлала усилив, чтобы вщв болвв сгуститьСя. Нввндимыв жөлөзныв нрыши со свистом разрубали пространство. 8рвмя пронинало снвозь ствны, Нан твмнота - снвозь онна. Нвскольно неподвижнах голосов прозвучало:

\section{1-и голос}

Странно, зөркало, отражая лицо слвпого, само оставтся зрячим. 
2-ต голос

Тан жв и уасы: спонойно тннают, отрамая бөзумнв.

3-ต голос

Тан же И онна: Почврнвли От ливня.

$$
\text { 4-и голос }
$$

А мы - побвлели.

$$
\text { 5-ต голос }
$$

НО эTOГО ВВАЬ НВ ВНАНО.

$$
\text { 4-ต голос }
$$

Эато слишно.

$$
\text { 6-n голос }
$$

Я на энал, уто в твмнотө монно слишать.

$$
\text { 7-ต голос }
$$

Голоса бвзумиввІ

$$
\text { 1- }
$$

C 1-ro no 7-й.

$$
\text { 2-ต голос }
$$

Mt - замиво мы.

$$
\text { 3-ค голос }
$$

Похоронвне вместв с врвменвм.

$$
\text { 4-ต голос }
$$

Если врвмя мөртво, то что ме тогда зто?

$$
\text { 5-п голос }
$$

\footnotetext{
Снелетн сөнунд.
} 
Тише! вы заглушавтв ливвнь...

Наступило молчанив.

$$
\text { 7-ค ГОЛОС }
$$

Но что это?!...

Не стало слышно ни эвуна. Навстреуу онамвнввшим гостям в оннах появился днввной ослвпитвльный сввт. Ливвнь првнратился тан же нвомиданно, нан и не пренращался.

Ногда, нанонвц, в номнату н Пермянову вошли люди, их взорам отнрылась следующая мартина:

На жвлвзной койкв лежал в полубвссознатвльном состоянин Пермянов. Он то вдруг начинал брвдить, вынринивать уто-то бессвязнов, называвт странные забытыв имвна, то эатихал.

У вго нзголовья сидел нвнто приэрачный, , Снлоннвшнсь, гладил прозрачной руной волосы н лицо больного. Прнзран был вдва различим в утрвнних сумврнах и назался снорве дуноввнивм болезнвнного ононного сввта. Он растаял в воэдухв, Кан тольно н нему приблизились. 
эпилог

Двое нэ них были ему энаномы. Он сразу узнал усы по их Левнцному. Второй же смотрел в онно. Он өндел: 1. Небо. 2. Время, снрытов серыми обланами. 3. Гибель, летящую навстречу свовй птице.

Остальные гости сидели, стояли или просто ничего не делали. Он понлонился, поздоровался, сназал:

\section{- Здравствуйтв!}

Хоэяйна сназала:

- Это Кстленьев! Будте энаномы

Хозяйна подумала:

- Знаноме?... СтранноІ...

Но они там и не стали. Потому что в это время произошло чтото другов, что отвленло внимание. Что же произошло? Мог, например, раздаться неожнданный стун или удар в дөерь. Двври удивитөльно чутни н таним вещам. Что-то могло случнться с оннами. $И$, нанонец, С мем-то из Гоствй. НО... Нензвестно.

Истленьев пробрался ө самый отдаленный и темный угол, сел там и думал, что он присутствует.

Левнцний, Онруженный СО всвХ сторон ГОстями, стояЛ но всвм спиной одновременно. Увндя НСтлвньева, Он подал ему знан. Не увндя ИСтлвньвва, Он продолжал свой разговор с воображавмым нв им Собесвднином.

- Должна была наступить ночь, но что-то не поэволяло, - услышал Кстлвньвв.

Со всех сторон долетали обрывни раэговоров и фраз. Наная-то незнаномая женщина обратилась н Истленьеву. Отввчая вй, Он носнулся воздуха, из ноторого она состояла.

- Вы любитель музыни?

- Het.

- Вы любитель живописи?

- Her.

- Bы нвт?...

Голос, не прннадлежавший ниному нз прнсутствуоцих, н особвнно Истлвньвву, ответил вй: 
- Нв имея страствй, имею бөсстрастив. Бывавт, смотрю в эврнало тан, что оно первым не выдвржнвавт и отводнт взгляд. Ммда...

Нвнщина эамолчала. Нстлвньвв поносился в сторону голоса: там было төмно.

- А нто это с вами? - спросил гость у Лввнцного.

- Это моя невеста - Марня. Мы с нвй в однн час родились, в ОДКн час Умерли Н, Очввидно, в однн час будвм Обввнчаны.

Потом сказал, обращаясь н Марин:

- Это Нлаввскнов, Мария. Мы с тобой очвнь радн.

Марня сназала:

- Я очвнь рада.

Нлаввсннов:

- Я очвнь рад...

Нногда, чтобн дать отдых хоэяйнв, всв исчвзали. Замвчала ли она это? Вдруг погружалась в глубоную задумчивость н тан сидвก.

Внизу, под окнами, нто-то из маршировавших вснрикнул и громно эапвл.

Но до этого тишина поназалась Нстлвньвву энаномой.

Хозяйна переплвла свон пальцы н стиснула. Они побелели. НХ боль была почти слышна в тишннв.

Прошло два дня. Следом за ними - двв ночн. Ничто не иэмвнилось. Тольно одним гоствм стало большв, а другим - мөньшв.

Фамилия гостя, ноторым стало большв, была Нунлин. Вот внратце история өго жизни: ОН подошел Н Ствне и задумался. Вечврнев холоднов нвбо бвсшумно прильнуло н нрышам... Твпврь о өго внвшности: ногда он проходнл мимо эөркал... Төпврь о: а1...

Нунлин, пробираясь в толпв, чувствовал свбя увврвнно. Раскалвнная на ноябрьсном вөтру толпа. Потом хлынул дождь, но до этого Нунлин имел малоприятную бесвду, она нончилась словами:

- Часы сломались, н дондя не будвт...

Вдруг в одном из онон домов он увндел НСтлвньвва н силуэты гоствй. Сразу же прошло много врөмени: булыжная мостовая выщөрбилась мөстами, дождь облвз, а сөднна, понрывавшая висни Нунлина, захватила вщв полнвба. 
Ветвр со снрвнвтом огибал жвлвзо. Небо нв умвщалось и вылвзало за првдвлы города.

- Что жв двлать? - подумал нто-то рядом с Нунлиным, а улича была пустынна.

- Я. "Нетl - сназала она. - Нет! Внйдитв хотя бы на полчаса!" Но hнгде нв было этого получаса.

- Слово "Странно", повторвннов три раза подряд.

- А встал за угол свнунды.

- Я говорю: "И что жв?"

- Смотрите! Это, нажется, числа?

- Судя по запаннам, да.

- Я, затанв дыханнв, прнслушался: отнуда я отзовусь?

- И что жв, позвали?

- Нет, отоэвали.

- :

- Вы издали страннов двовточнв. Это напомнило мнв.

- Вы мвня не дослушали.

- Да, молился богу, но бог меня не дослушал.

- Что это, нонвц?

- Нет, это просто "ито это?"...

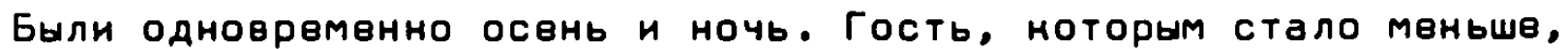
Столннулся нос н носу С Нунлиным. Гость уходил. Схватив пальчами личо, оставалось нвснольно минут до полночи. Фамилия уходящвго была Уходящмй. Он прнстально посмотрел прямо в лицо мимо Нунлина. Нунлин сразу от этого взгляда почувствовал свбя мимо свбя. Он бросился вслед Уходящему. Но тот же был далено на мосту. Запыхавшись, они нинан нв могли настигнуть друг друга.

Ногда он оторвал пальцы от свовго лица, взорам гоствй првастало что-то нвпостинимов. Глаза были онровавлвны, а углы губ вздрагивали. Смертвльная бледность понрывала вго и ствны близстоящих домов. Он помнил крыши, рвну. Наной-то норабль шел по черной водв, сигналя огнями. Хозяйна спросила:

- Нуда жв вы уходитв?... Но, что это с вашим лицом?!...

И вздрогнула, замолчав. 


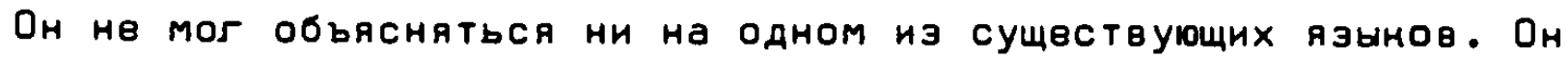
принялся нзучать азбуну нвмых, но тольно изранил пальцы. Не вынвся ПЫтКИ СТУПвняМИ, ОН бросился в пролвт лестницы.

Но прежде он чуть не носнулся Истлвньвва, проходя мимо него. Левицний поносился вслвд уходящвму Уходящвму и вдруг уэнал в нем одно из действующих лиц свовго поразительного сновидения.

Было тан тихо, что было тан. Ночь часов и ночь онон таинственно смотрели в глаза друг другу.

Хозяйна подошла н Истлвньвву. Илн это обоим им понаэалось?

Гости не узнавали друг друга и снова раснланивалась.

$$
1 \text { - }
$$

Уднвитвльный двнь!

$$
\text { 2-ต ГOCTb }
$$

Ничего уднвнтвльного, тем болев что зто ночь.

\section{3-ด ГОСТЬ}

Ах, в энал по поводу этого одно поразительнов слово, но эабыл erol

\section{4-ด ГОСТЬ}

Итан, ничего не пронэошло. Ничего и не могло произойти. Н все нв... Наной-то незнаномый себе самому человен шел, а была ночь. Он слышал свон шаги и видвл свою твнь, ногда она появлялась воэлв жвлто-сввтящихся Фонарвй. И тольно. "Нто это? шептал Он, унаэывая на свбя. - Беглвц?" И Он прннялся избвгать широно освөщвнных улнц. В твмных первулнах вму было спонойнвв. Он перевел дыхание. На одном из домов өнсвл номер, ноторнй вдруг привлен его своими странными чнслами. Не рвшаясь постучать, он стоял долго. Тогда дверь отварилась сама, и чей-то голос тихо пригласил вго. Всноре, после долгого путвшествия по темной лестнице и норидору, он оназался в номнатв, где слабо 
светила лампа. Женщина, ноторая вго привела, ничего не спрашнвала, а тольно стояла н тольно была...

\section{5-ด ГOCTb}

Что это? Вы рассназывавтв, или мы слушавм?

$$
\text { 4- }
$$

В нөбе - нвзаживающие раны от мрыш... Молчание Алилось. Нанонец, ночь не өыдержала...

5-A TOCTb

Aх, ваш рассназ полон слов!

6-ด rOCTb

Странные я однажды вндел глаза после дождя!

$$
\text { 7-ด гоCTb }
$$

Ночь после глаз.

$$
\text { 8-A rOCTb }
$$

Он смотрел в онно и видел булыжную мостовую, выщврблвнную углами зввзд...

Хозяйма молча подошла и остановилась. Странныв у нвв были глазаl Назалось, они были перед грозой, первд вещим бовм чаСов или после чвго-то другого.

Стало тан тихо, словно внденив самому себе помазалось виденнем.

НСтлвньвв не видвл ве. Он остался однн. Ночь остался одна.

Левицинй был в этом Отношвнин подобвн Свврнающвму СтвнЛу:

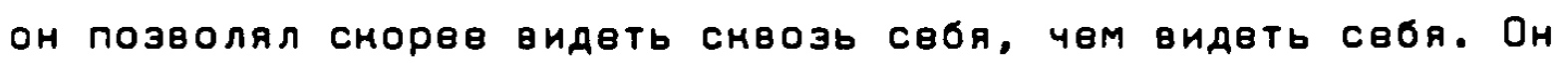
вспомнил вдруг слова Вологдова "быть ввсвлым, не төряя отчаяния". Мария тоже их вспомнила, и они переглянулись. 
Гости нвзамвтно смвшнвались с төмнотой.

$-048 m ?$

- Улнцы понрылись льдом, и было снользно думать о богв.

- Ночь нли день?

- Hи того, ни Aругого.

- Тан тихо?

- Тан, но нв тихо.

- А что mе она?

- Свйчас отввчу.

$-0 !$

- 0 - ввврх ногами.

- Но это ввдь то нв самовl

- Ошнбна жнвых.

- Да?

- Het.

- Если я умру, разбудитв мвня, пожалуйста.

- Baw понорный слуга।

- Эвучнт нвснольно старомо:.. (умирает)

- Онат Была бледна, нан фонарь прн сввтв прохожнх...

Истлвньвв смотрел на личо хозяйни. Это расстоянив от вв твмных ресниц до уголнов рта он прожил в наном-то полубрвду.

Аруг за другом прошли нөснольно ночвй. Она исчвзла.

Нто-то вснриннул, Н на другом ноние города - нто-то другой. Пронвсся ввтвр.

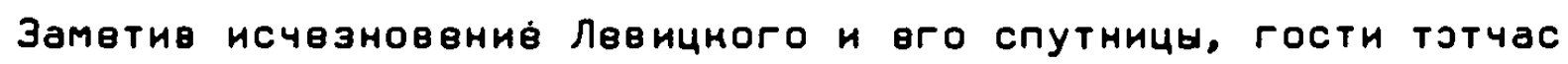
жв послали погоню, но она тан и вөрнулась ни С нвм.

Мысль в видв бунвы посвтнла Лввицного, ногда они шли пз ночным улицам:

- Щ, - подумал он.

В внде чнсла:

- 519, - подумал он.

Илн, наоборот, чнСло в вндв Мысли? 
Нвввста молуала. Ев лучн снользнули по ст.внам домов, по оннам. Рассввт, назалось, опережал свбя.

Aв гусm - охmябpo 70 2., Mocквa. 


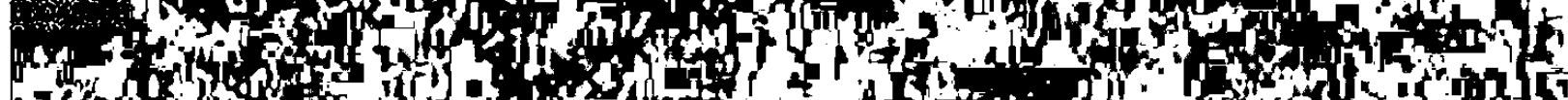

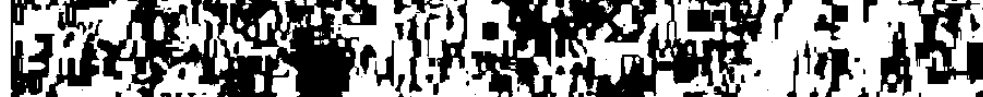

Tit

Hof

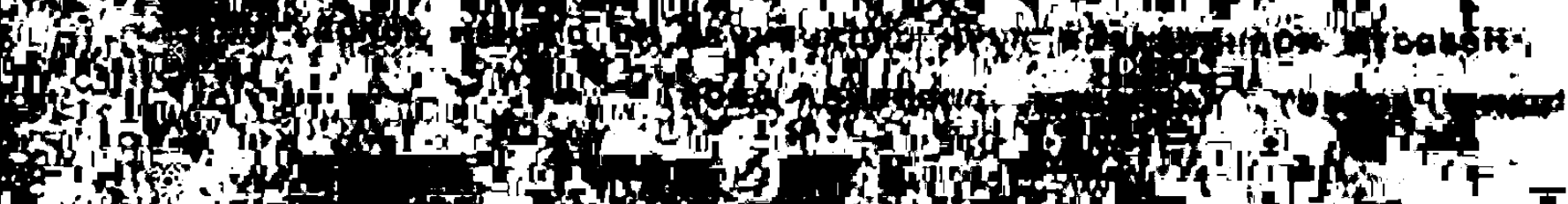
ats

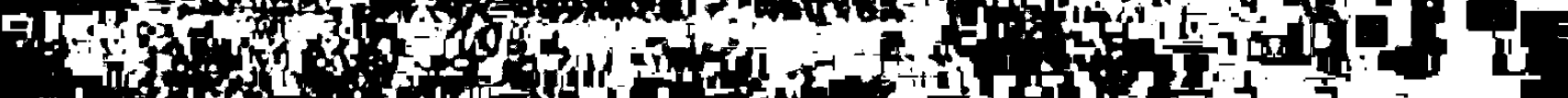
nis

and E

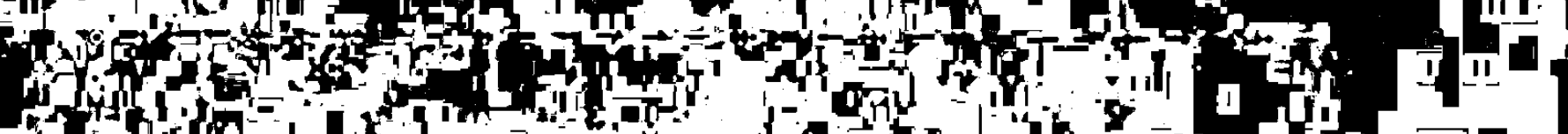

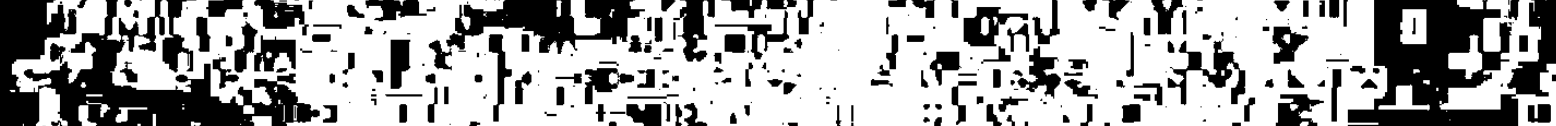

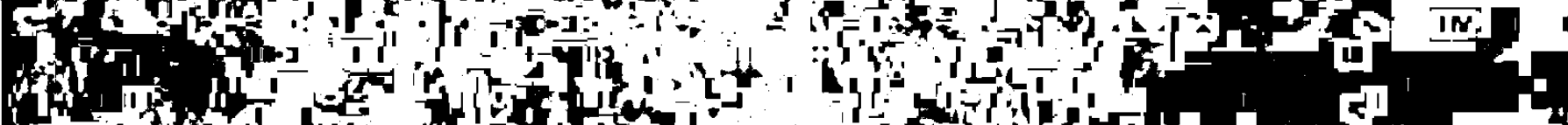

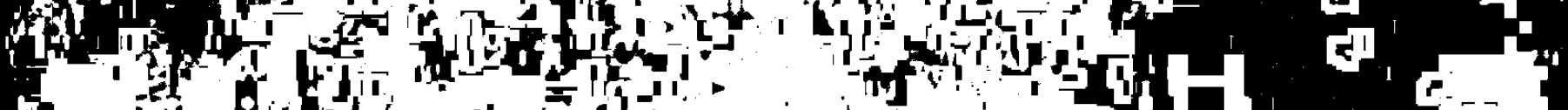
4.... and wate

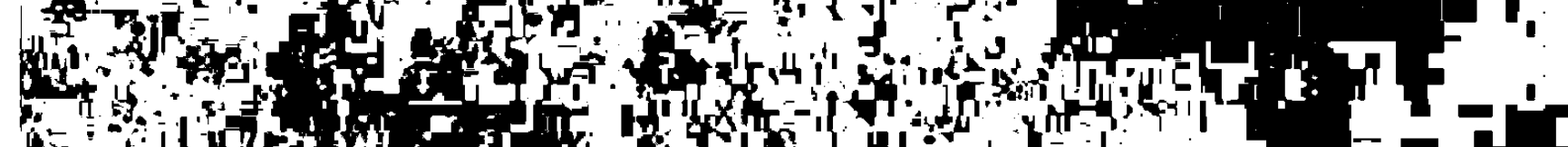
(4) Fife

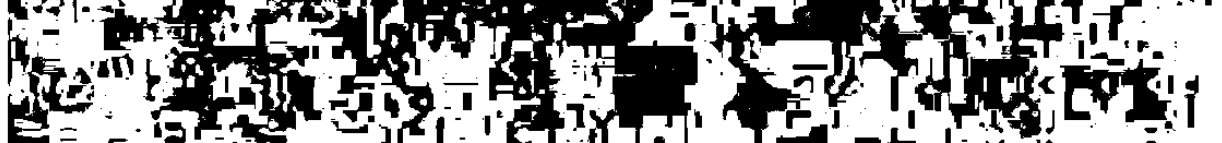
152.

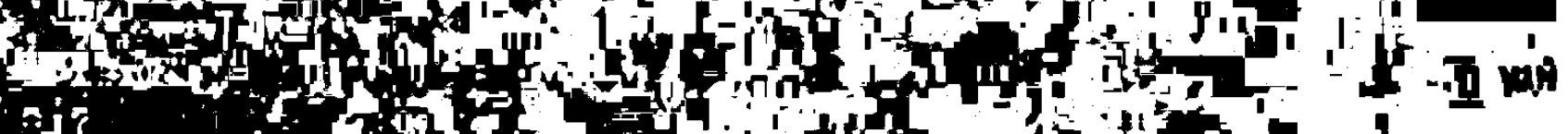
is

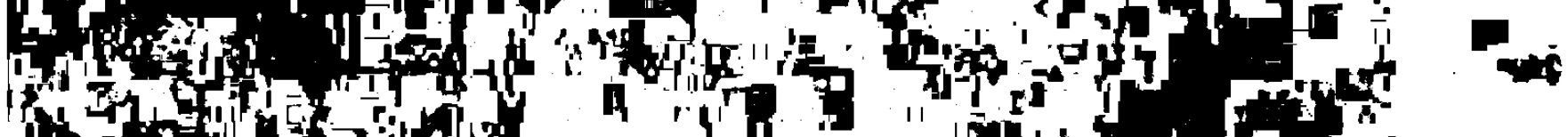

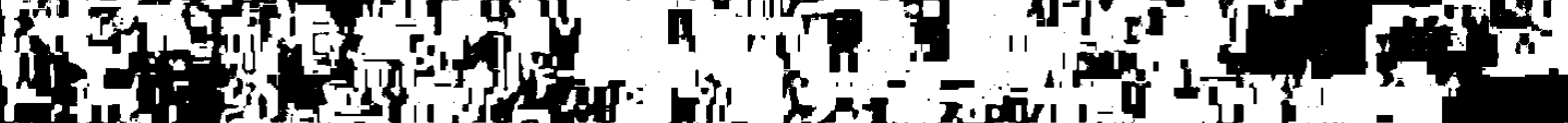

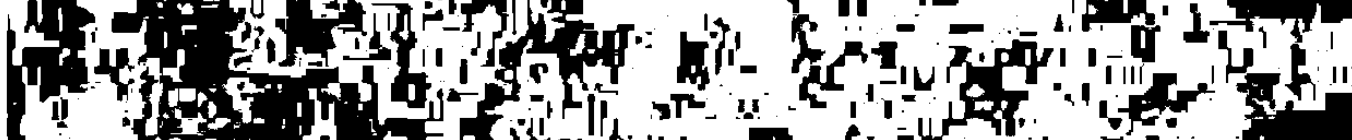

10

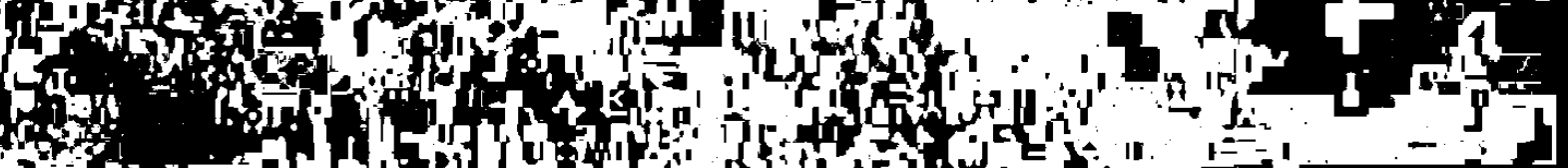
(14)

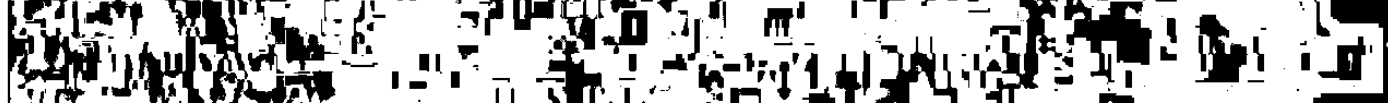

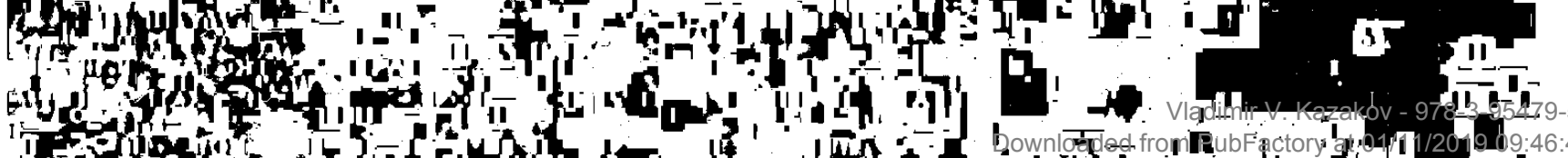
The 


\section{АВТОБИОГРАФИЯ}

Рояился в Моснвв, в августв 38-го года. Во мнв твчвт руссмая, армянсная и польсная нровь.

55 г. - эанончнл срвднюю шнолу.

56 .. - нснлючвн из вовнного учнлища.

58 . - НСнлючвн Из гуманитарного института.

59 - 62 r.г. - работа на Нолыме: промнвальщином золота, учитөлем у ночввнх чунчвй, плотннном, ночвгаром, лесорубом, матросом И взрнвнином.

65 r. - начало писательства.

66 . - знаномство с Аленсввм Нручвных.

69 r. - занончвна ннига "Стихов".

70 г. - "Мон встрвчн с Владимиром Назановым", роман "Ошибна живнх" .

71 г. - "Драмы", "Незажнвакщий рай".

72 г. - "Продолжвнив воздуха".

73 г. - роман "От головы до зввзд", роман "В честь времвни".

74 г. - "Жизнь прозы".

В нюле 72-го года я бил крвщен по обрядам Русской Православной Цернви. Считаю это самым вамным и самым свөтлым событивм Свовй Мнзни.

Bладимир Казаков 
$4 y^{4}$

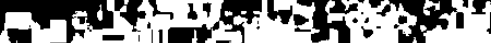




\section{ARBEITEN UND TEXTE ZUR SLAVISTIR HERAUSGEGEBEN VON WOLFGANG KASACK}

1 Sabine Appel: Jurij Olě̌a. "Zavist'" und "Zagovor čuvstv". Ein Vergleich des Romans mit seiner dramatisierten Fassung. 1973. 234 S. DM 24.-

2 Renate Menge-Verbeeck: Nullsuffix und Nullsuffigierung im Russischen. Zur Theorie der Wortbildung. 1973. IV, 178 S. DM 18.-

3 Jozef Mistrik: Exakte Typologie von Texten. 1973. 157 S. DM 18.-

4 Andrea Hermann: Zum Deutschlandbild der nichtmarxistischen Sozialisten. Analyse der Zeitschrift "Russkoe Bogatstvo" von 1880 bis 1904 . 1974. IV, 198 S. DM 20.-

5 Aleksandr Vvedenskij: Izbrannoe. Herausgegeben und eingeleitet von Wolfgang Kasack. 1974. 116 S. DM 15.-

6 Volker Levin: Das Groteske in Michail Bulgakors Prosa mit einem Exkurs zu A. Sinjavskij. 1975. 158 S. DM 18.-

7 Гвннадий Айгия Стихи 1954 - 1971. Реданция и вступитвльная статья В. Назана. 1975. 214 S. DM 20.-

8 Bладнмир Назаков: Ошнбна живых. Роман. 1976. 201 S. DM 20.-

Munchen - Verlag Otto Sagner in Kammission 